\title{
Fracture Evaluations of
}

Fusion Line Cracks in

Nuclear Pipe Bimetallic Welds

Prepared by

P. Scott, R. Francini, S. Rahman, A. Rosenfield, G. Wilkowski

\section{Battelle}

Prepared for

U.S. Nuclear Regulatory Commission 


\section{AVAILABILITY NOTICE}

Availability of Reference Materials Cited in NRC Publications

Most documents cited in NRC publications will be available from one of the following sources:

1. The NRC Public Document Room, 2120 L Street. NW., Lower Level, Washington, DC 20555-0001

2. The Superintendent of Documents, U.S. Government Printing Office. P. O. Box 37082, Washington, DC 20402-9328

3. The National Technical Information Service. Springfield. VA 22161-0002

Although the listing that follows represents the majority of documents cited in NRC publications, it is not intended to be exhaustive.

Referenced documents avallable for inspection and copying for a fee from the NRC Public Document Room Include NRC correspondence and internal NRC memoranda: NRC bulletins. circulars, information notices. inspection and investigation notices; licensee event reports: vendor reports and correspondence; Commission papers: and applicant and licensee documents and correspondence.

The following documents in the NUREG series are available for purchase from the Government Printing Office: formal NRC staff and contractor reports. NRC-sponsored conference proceedings. international agreement reports, grantee reports, and NRC booklets and brochures. Also available are regulatory guides, NRC regulations in the Code of Federal Regulations. and Nuclear Regulatory Commission Issuances.

Documents available from the National Technical information Service include NUREG-series reports and technical reports prepared by other Federal agencies and reports prepared by the Atomic Energy Commission. forerunner agency to the Nuclear Regulatory Commission.

Documents available from public and special technical libraries include all open literature items, such as books, journal articles, and transactions. Federal Register notices. Federal and State legislation, and congressional reports can usually be obtained from these libraries.

Documents such as theses, dlssertations, foreign reports and translations, and non-NRC conference proceedings are avallable for purchase from the organization sponsoring the publication cited.

Single copies of NRC draft reports are available free. to the extent of supply. upon written request to the Office of Administration, Distribution and Mail Services Section. U.S. Nuclear Regulatory Commission, Washington. DC 20555-0001.

Copies of industry codes and standards used in a substantive manner in the NRC regulatory process are maintained at the NRC Library. Two White Flint North. 11545 Rockville Pike. Rockville. MD 20852-2738, for use by the public. Codes and standards are usually copyrighted and may be purchased from the originating organization or. if they are American National Standards. from the American National Standards Institute, 1430 Broadway, New York, NY 10018-3308.

\section{DISCLAIMER NOTICE}

This report was prepared under an international cooperative agreement for the exchange of technical information. Neither the United States Government nor any agency thereof, nor any of their employees, makes any warranty, expressed or implied, or assumes any legal liability or responsibility for any third party's use, or the results of such use, of any information, apparatus, product, or process disclosed in this report, or represents that its use by such third party would not infringe privately owned rights. 


\section{DISCLAIMER}

Portions of this document may be illegible in electronic image products. Images are produced from the best available original document. 
NUREG/CR-6297

BMI-2182

\section{Fracture Evaluations of Fusion Line Cracks in \\ Nuclear Pipe Bimetallic Welds}

Manuscript Completed: January 1995

Date Published: April 1995

Prepared by

P. Scott, R. Francini, S. Rahman, A. Rosenfield, G. Wilkowski

Battelle

505 King Avenue

Columbus, OH 43201

Prepared for

Division of Engineering Technology

Office of Nuclear Regulatory Research

U.S. Nuclear Regulatory Commission

Washington, DC 20555-0001

NRC Job Code B5702 


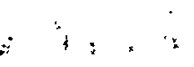


Abstract

\begin{abstract}
In both BWRs and PWRs there are many locations where carbon steel pipe or components are joined to stainless steel pipe or components with a bimetallic weld. The objective of the research described in this report was to assess the accuracy of current fracture analyses for the case of a crack along,a carbon steel to austenitic weld fusion line. To achieve the program objective, material property data and data from a large-diameter pipe fracture experiment were developed to assess current analytical methods. The bimetallic welds evaluated in this program were bimetallic welds obtained from a cancelled Combustion Engineering plant. The welds joined sections of the carbon steel cold-leg piping system to stainless steel safe ends that were to be welded to stainless steel pump housings. The major conclusion drawn as a result of these efforts was that the fracture behavior of the bimetallic weld evaluated in this program could be evaluated with reasonable accuracy using the strength and toughness properties of the carbon steel pipe material in conjunction with conventional elastic-plastic fracture mechanics or limit-load analyses. This may not be generally true for all bimetallic welds, as discussed in this report.
\end{abstract}


EXECUTIVE SUMMARY $\ldots \ldots \ldots \ldots \ldots \ldots \ldots \ldots \ldots \ldots \ldots \ldots \ldots \ldots \ldots$

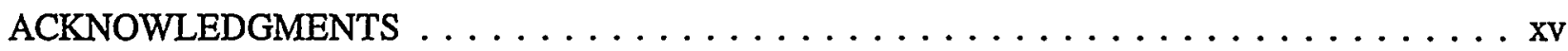

NOMENCLATURE $\ldots \ldots \ldots \ldots \ldots \ldots \ldots \ldots \ldots \ldots \ldots \ldots \ldots \ldots \ldots \ldots$

PREVIOUS REPORTS IN SERIES $\ldots \ldots \ldots \ldots \ldots \ldots \ldots \ldots \ldots \ldots \ldots \ldots \ldots$

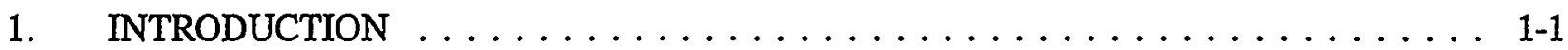

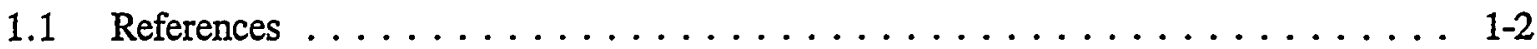

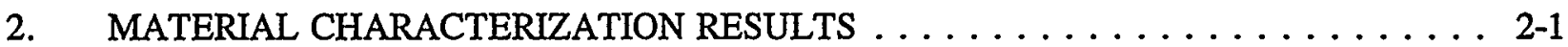

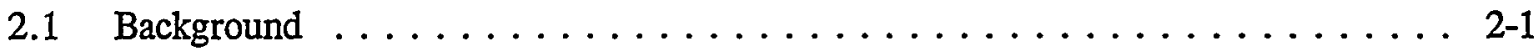

2.2 Material Description ......................... 2-1

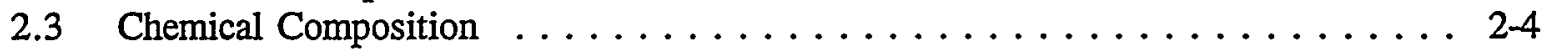

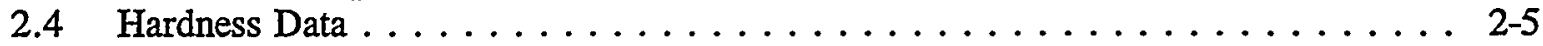

2.5 Tensile Data . . . . . . . . . . . . . . . . . . . . 2-7

2.5.1 Carbon Steel Base Metal Tensile Properties . . . . . . . . . . . . . . 2-7

2.5.2 Stainless Steel Safe-End Tensile Properties . . . . . . . . . . . . . . . . 2-9

2.5.3 Inconel Weld Metal Tensile Properties . . . . . . . . . . . . . . . . 2-9

2.6 Charpy V-Notch Impact Test Data . . . . . . . . . . . . . . 2-11

2.6.1 Charpy Data from A516 Grade 70 Carbon Steel Base Metal Material . . . 2-11

2.6.2 Charpy Data for the Carbon Steel Pipe/Inconel 182 Fusion Line . . . . . 2-16

2.7 J-Resistance Curve Test Data from C(T) Specimens . . . . . . . . . . . . 2-19

2.7.1 J-R Curve Data for A516 Grade 70 Carbon Steel Pipe Material . . . . . . . 2-19

2.7.2 J-R Curve Data for SA182 F316 Forged Stainless Steel Safe-End Material . 2-22

2.7.3 J-R Curve Data for the A516 Grade 70 Pipe/Inconel 182 Fusion-Line Region 2-24

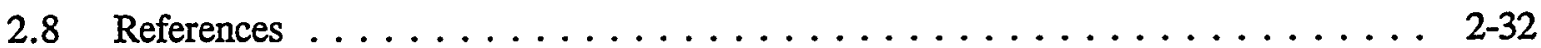

3. PIPE EXPERIMENTS ......................... $3-1$

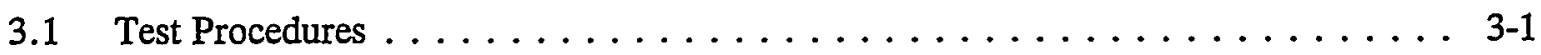

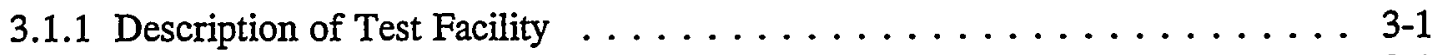

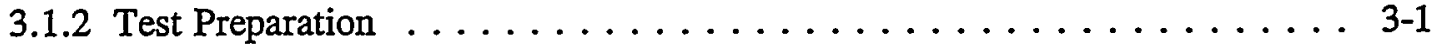

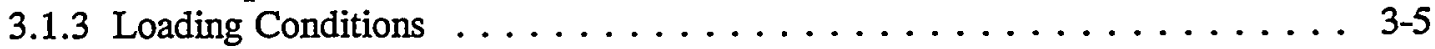




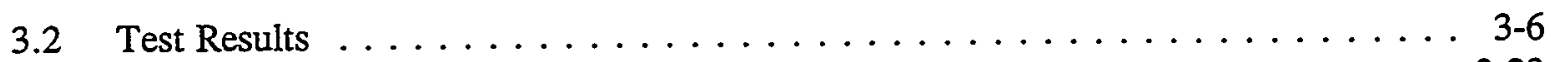

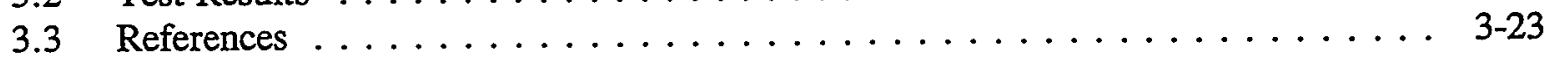

4. ANALYSIS OF PIPE FRACTURE EXPERIMENT $\ldots \ldots \ldots \ldots \ldots \ldots \ldots$ 4-1

4.1 Comparison of Results with Fracture Prediction Analyses . . . . . . . . 4-1

4.1.1 Comparison of the Experimental Moment at Crack Initiation with Fracture Analyses Predictions . . . . . . . . . . . . . 5

4.1.2 Comparison of the Maximum Experimental Moment with Fracture Analyses Predictions . . . . . . . . . . . . . . . . .

4.1.3 Comparison of the Predicted and Experimental Moment-Rotation Curves for Experiment 1.1.1.28 $\ldots \ldots \ldots \ldots \ldots \ldots \ldots \ldots \ldots$ 4 $4-10$

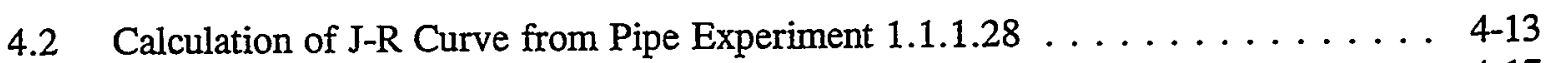

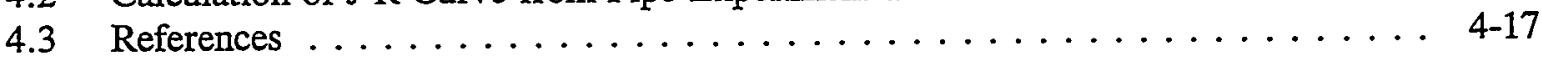

5. DISCUSSION AND SIGNIFICANCE OF RESULTS $\ldots \ldots \ldots \ldots \ldots \ldots \ldots$ 5-1

5.1 Discussion of Results from Material Characterization, Pipe Experiments, and Analyses Efforts . . . . . . . . 5.1

5.2 Potential Fracture Behavior of Different Bimetallic Weld Configurations Involving Different Material Combinations . . . . . . . . . . . 5-6

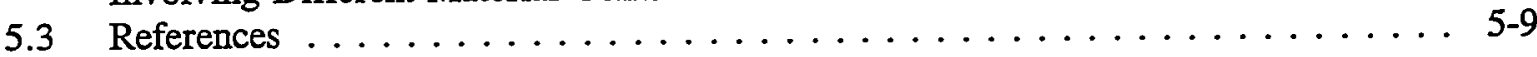

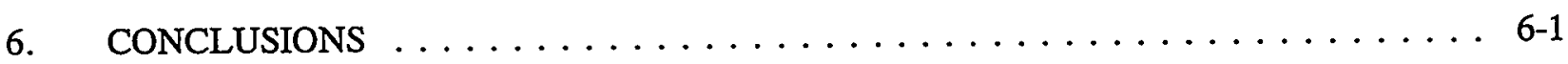


Figures

2.1 Cross section of bimetallic weld evaluated in this program showing various materials

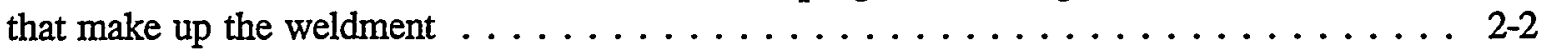

2.2 Bimetallic weld (DP2-F33W) showing repair weld $\ldots \ldots \ldots \ldots \ldots \ldots \ldots$

2.3 Hardness map of bimetallic weld (Pipe DP2-F33) $\ldots \ldots \ldots \ldots \ldots \ldots \ldots \ldots$

2.4 Hardness traverses across bimetallic weld fusion lines $\ldots \ldots \ldots \ldots \ldots \ldots$

2.5 Engineering stress-strain curves at $288 \mathrm{C}(550 \mathrm{~F})$ for A516 Grade 70 carbon steel pipe

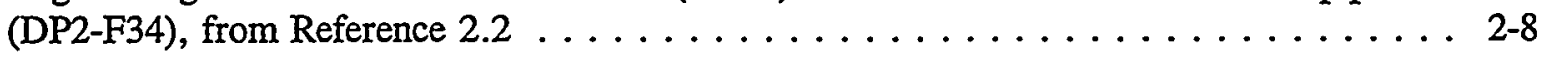

2.6 True stress-strain curves at $288 \mathrm{C}(550 \mathrm{~F})$ for A516 Grade 70 carbon steel pipe

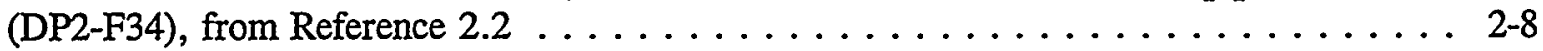

2.7 Engineering stress-strain curve at $288 \mathrm{C}(550 \mathrm{~F})$ for SA182 F316 stainless steel

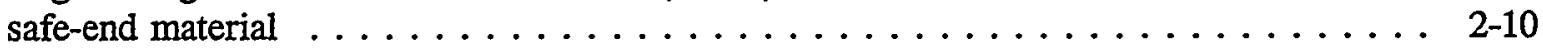

2.8 True stress-strain curve at $288 \mathrm{C}(550 \mathrm{~F})$ for SA182 F316 stainless steel safe-end material $\ldots \ldots \ldots \ldots \ldots \ldots \ldots \ldots \ldots \ldots \ldots \ldots \ldots$. . . . . . . . . . . . . .

2.9 Engineering stress-strain curves at $288 \mathrm{C}(550 \mathrm{~F})$ for the Inconel 182

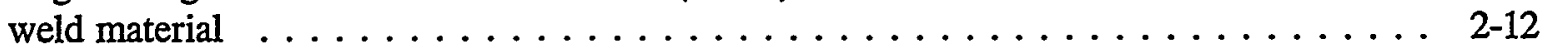

2.10 True stress-strain curves at $288 \mathrm{C}(550 \mathrm{~F})$ for the Inconel 182 weld material $\ldots \ldots \ldots$. . . 12

2.11 Absorbed energy in CVN tests for A516 Grade 70 Pipe DP2-F34 (L-C Orientation), from Reference $2.2 \ldots \ldots \ldots \ldots \ldots \ldots \ldots \ldots \ldots \ldots \ldots$. . . . . . . . . . . . . . . . . .

2.12 Fracture appearance (shear area percent) in CVN tests for A516 Grade 70 Pipe DP2-F34

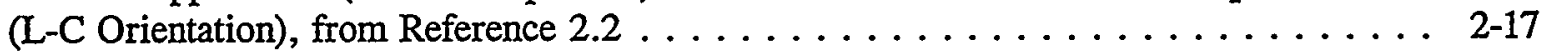

2.13 SEM photograph of Charpy Specimen Number 4 showing first part of the fracture path in the carbon steel immediately adjacent to the weld $\ldots \ldots \ldots \ldots \ldots \ldots$

2.14 SEM photograph of L-C oriented Charpy Specimen Number 4 showing crack veering away from the fusion line and into the carbon steel $\ldots \ldots \ldots \ldots \ldots$

2.15 Photomicrograph of tip of crack in delamination of Charpy specimen of bimetallic weld DP2-F33 . . . . . . . . . . . . . . . . . 2-19

2.16 J-resistance curves for A516 Grade 70 base metal (Pipe F34) 4T planform-size compact specimens tested at $288 \mathrm{C}(550 \mathrm{~F})$ from Reference $2.2 \ldots \ldots \ldots \ldots$. . . . . . 21 


\section{CONTENTS}

$\underline{\text { Page }}$

2.17 J-resistance curves for A516 Grade 70 base metal (Pipe F34) 1T compact specimens

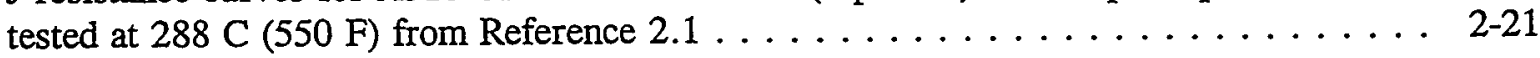

$2.18 \mathrm{~J}$-resistance curves for SA182 F316 forged stainless steel safe end tested

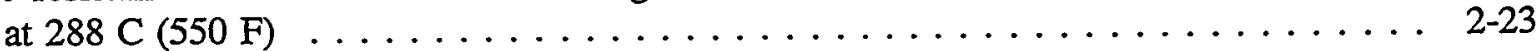

2.19 Photographs of the sides of the etched $\mathrm{C}(\mathrm{T})$ specimens prior to test showing the locations of the electric-discharge-machine (EDM) notches with respect to the weld fusion line, (a) DP2-F33W-1, (b) DP2-F33W-2, (c) DP2-F33W-3,

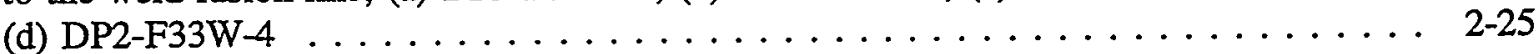

2.20 Fracture surface of broken bimetallic weld compact specimen DP2-F33W-4, (a) $2 \mathrm{X}$ Side View, (b) $4 \mathrm{X}$ Side View, (c) $2 \mathrm{X}$ Plan View, (d) $4 \mathrm{X}$ Plan View . . . . . . . 2-28

$2.21 \mathrm{~J}$-resistance curves for fatigue-precracked fusion-line $\mathrm{C}(\mathrm{T})$ specimens

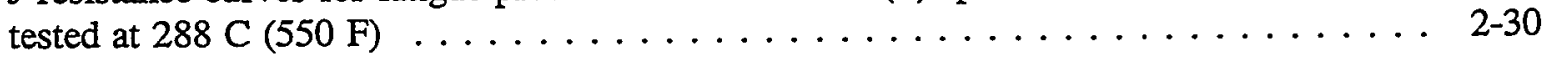

$2.22 \mathrm{~J}$-resistance curves for sharp-machined notch fusion-line $\mathrm{C}(\mathrm{T})$ specimens

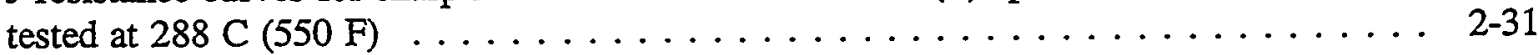

2.23 Composite J-resistance curves for bimetallic weld fusion-line $C(T)$ specimens

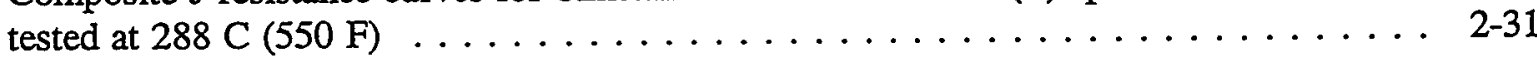

3.1 Schematic of four-point-bend strongback facility used to perform

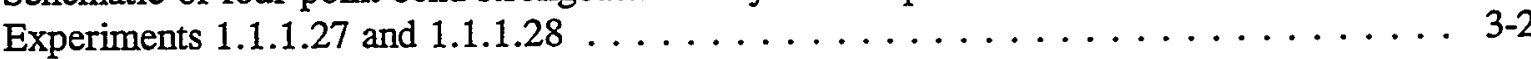

3.2 Post-test photograph of pipe specimen for Experiment 1.1.1.28 in four-point-bend

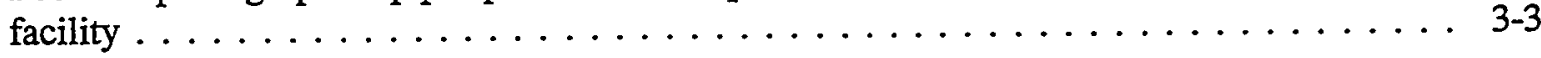

3.3 Schematic of ovalization device used for Experiments 1.1.1.27 and 1.1.1.28 . . . . . 3-6

3.4 Load as a function of pipe displacement at the load point for Experiment 1.1.1.28 . . . . 3-7

3.5 Rotation as a function of pipe displacement as the load point, (a) Experiment 1.1.1.27 (b) Experiment 1.1.1.28 ........................ 3-9

3.6 Schematic of the beam device used to measure rotations during Experiments 1.1.1.27 and 1.1.1.28, (a) End View, (b) Side View . . . . . . . . . . . . . 3-10

3.7 Moment as a function of total rotation $(2 \phi)$ for Experiment 1.1.1.28 $\ldots \ldots \ldots \ldots$

3.8 d-c electric potential as a function of corresponding crack tip CMOD used to determine crack initiation, (a) Crack Tip A Experiment 1.1.1.27,

(b) Crack Tip B Experiment 1.1.1.27, (c) Crack Tip A Experiment 1.1.1.28,

(d) Crack Tip B Experiment 1.1.1.28 
3.9 Centerline, midway between centerline and Crack Tip B, Crack Tip A, and Crack Tip B crack-mouth-opening displacements as a function of the pipe displacement at the load point, (a) Experiment 1.1.1.27, (b) Experiment 1.1.1.28 . . . 3 3-15

3.10 Moment as a function of crack centerline CMOD for Experiment 1.1.1.28 . . . . . 3-16

3.11 Photographs of crack growth, (a) Experiment 1.1.1.27 Crack Tip A,

(b) Experiment 1.1.1.27 Crack Tip B, (c) Experiment 1.1.1.28, Crack Tip A,

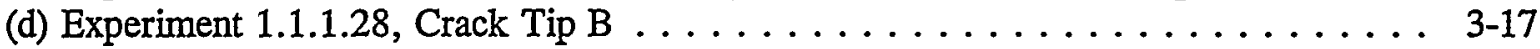

3.12 Comparison of crack growth as a function of pipe displacement at the load point for Experiments 1.1.1.27 and 1.1.1.28 . . . . . . . . . . . 3-19

3.13 Crack tip CMOD as a function of crack growth, (a) Experiment 1.1.1.27,

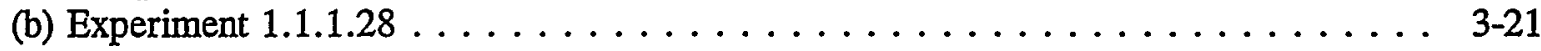

3.14 Ovalization of the pipe near the crack plane as a function of pipe displacement at the load point, (a) Experiment 1.1.1.27, (b) Experiment 1.1.1.28 . . . . . . 3-22

4.1 Quasi-static stress-strain data at $288 \mathrm{C}(550 \mathrm{~F})$ for A516 Grade 70 carbon steel pipe base material with Ramberg-Osgood representation of the stress-strain data

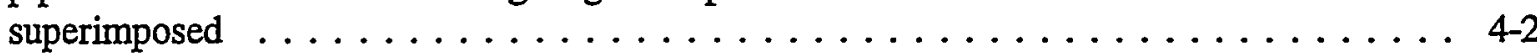

4.2 Quasi-static stress-strain data at $288 \mathrm{C}(550 \mathrm{~F})$ for F316 stainless steel safe-end base material with Ramberg-Osgood representation of the stress-strain data superimposed $\ldots \ldots \ldots \ldots \ldots \ldots \ldots \ldots \ldots \ldots . \ldots \ldots$

4.3 Quasi-static stress-strain data at $288 \mathrm{C}(550 \mathrm{~F})$ for Inconel $182 \mathrm{SMAW}$ weld metal with Ramberg-Osgood representation of the stress-strain data superimposed . . . . . . . 4-3

4.4 Extrapolated quasi-static $\mathrm{J}_{\mathrm{D}}-\mathrm{R}$ curve at $288 \mathrm{C}(550 \mathrm{~F})$ for weld fusion-line with actual $C(T)$ specimen data superimposed [Data considered valid for

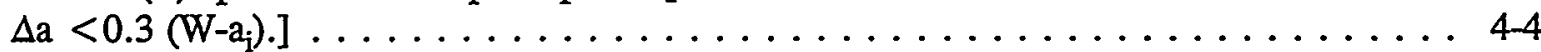

4.5 Comparison of experimental moment at crack initiation with predicted moments at crack initiation for Experiment 1.1.1.28 using three different stress-strain curves in the analyses and six different analysis methods (using fusion-line $C(T)$ specimen J-R curve data) . . . 4-6

4.6 Comparison of maximum experimental moment with maximum predicted moments for Experiment 1.1.1.28 using the fusion-line $C(T)$ specimen $\mathrm{J}_{\mathrm{D}}-\mathrm{R}$ curve with the carbon steel pipe stress-strain curve and nine different analysis methods $\ldots \ldots \ldots \ldots \ldots \ldots$ 4-8

4.7 Comparison of maximum experimental moment with maximum predicted moments for Experiment 1.1.1.28 using the fusion line $C(T)$ specimen $J_{D}-R$ curve with the stainless steel safe-end stress-strain curve and nine different analysis methods $\ldots \ldots \ldots \ldots .4-9$ 
4.8 Comparison of maximum experimental moment with maximum predicted moments for Experiment 1.1.1.28 using the fusion-line $C(T)$ specimen $J_{D}-R$ curve with the Inconel 182 weld stress-strain curve and nine different analysis methods

4.9 Comparison of the experimental moment-rotation curve with the predicted moment-rotation curves from five analysis methods using the A516 Grade 70 carbon steel pipe stress-strain data $\ldots \ldots \ldots \ldots \ldots \ldots \ldots \ldots \ldots$

4.10 Comparison of the experimental moment-rotation curve with the predicted moment-rotation curves from five analysis methods using the F316 stainless steel safe-end stress-strain data . . . . . . . . . . . . . . . . .

4.11 Comparison of the experimental moment-rotation curve with the predicted moment-rotation curves from five analysis methods using the Inconel 182 weld

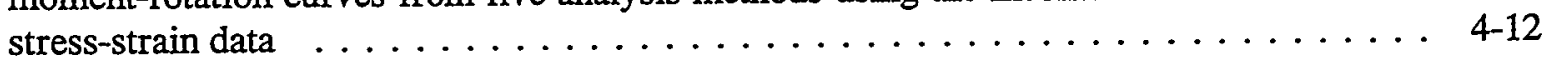

4.12 Comparison of the experimental moment-rotation curve with the predicted moment-rotation curves from five analysis methods using the A516 Grade 70 carbon steel pipe stress-strain data and the $J_{m}-R$ curve for the fusion line

4.13 Comparison of J-resistance curve for Experiment 1.1.1.28 calculated using the $\eta$-factor method with the extrapolated $\mathrm{J}_{\mathrm{D}}-\mathrm{R}$ curves from $2 \mathrm{~T} \mathrm{C}(\mathrm{T})$, sharp-machine-notch,

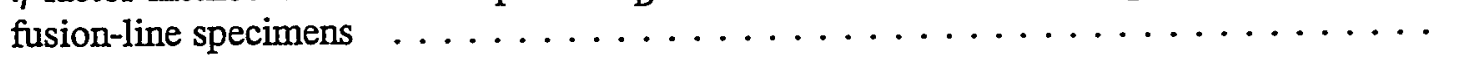

5.1 J-R curves for F316 stainless steel safe end, A516 Grade 70 carbon steel pipe, and fusion-line of the carbon steel and Inconel 182 buttering passes. Also shown on this figure is the J-R curve for a stainless steel submerged-arc weld evaluated in IPIRG-1 $($ Ref. 5.1$) \ldots \ldots \ldots \ldots \ldots \ldots \ldots \ldots \ldots$

5.2 Bending stress (i.e., crack section moment normalized by uncracked pipe section modulus) for the three cold-leg pipe experiments conducted as part of the Degraded Piping Program

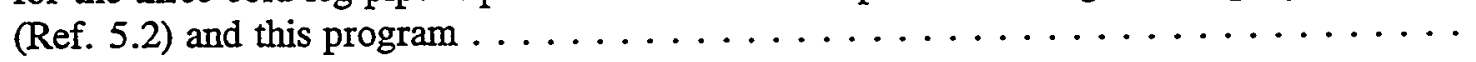

$5.3 \mathrm{~J}$-values at $1 \mathrm{~mm}(0.04 \mathrm{inch})$ and $2 \mathrm{~mm}(0.08 \mathrm{inch})$ of crack extension for bimetallic welds evaluated by NRI-Rez and from this program. ............... 
Tables

2.1 Chemical composition of base materials and Inconel weld metal in bimetallic

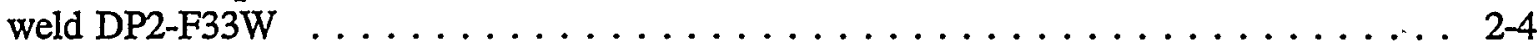

2.2 Tensile properties of A516 Grade 70 Pipe DP2-F34 in the longitudinal direction (Ref. 2.2) . . . . . . . . . . . . . . . . . . . . 2-7

2.3 Quasi-static tensile properties of SA182 F316 forged stainless steel safe-end

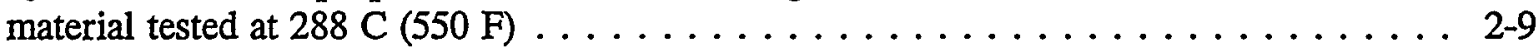

2.4 Quasi-static tensile properties of Inconel 182 weld (DP2-F33W) in 914-mm (36-inch)

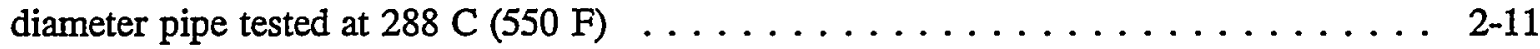

2.5 Results of Charpy V-notch impact tests for A516 Grade 70 Pipe DP2-F34 (L-C orientation, near inside pipe surface location) [Specimens were fabricated and tested by Materials Engineering Associates (Ref. 2.2)]

2.6 Results of Charpy V-notch impact tests for A516 Grade 70 Pipe DP2-F34 (L-C orientation, midwall location) [Specimens were fabricated and tested by Materials Engineering Associates (Ref. 2.2)] . . . . . . . . . . . . . . 2-14

2.7 Results of Charpy V-notch impact tests for A516 Grade 70 Pipe DP2-F34 (L-C orientation, near outside pipe surface location) [Specimens were fabricated and tested by Materials Engineering Associates (Ref. 2.2)] . . . . . . . . . . . 2-15

2.8 Results of Charpy V-notch impact tests at $288 \mathrm{C}(550 \mathrm{~F})$ on specimens from the bimetallic weld fusion line $(\mathrm{L}-\mathrm{C}$ orientation) $\ldots \ldots \ldots \ldots \ldots \ldots \ldots \ldots$

2.9 Summary of $\mathrm{J}_{\mathrm{i}}$ and $\mathrm{d} J / \mathrm{da}$ values for A516 Grade 70 base metal Pipe DP2-F34 compact specimens (Tested at $288 \mathrm{C}(550 \mathrm{~F}) ; \mathrm{L}-\mathrm{C}$ orientation) $\ldots \ldots \ldots \ldots \ldots \ldots \ldots$ 2-22

2.10 Summary of $\mathrm{J}_{\mathrm{i}}$ and $\mathrm{dJ} / \mathrm{da}$ values for SA182 F316 forged stainless steel safe-end material tested at $288 \mathrm{C}(550 \mathrm{~F})$ on $1 \mathrm{~T} \mathrm{L-C}$ oriented compact specimens $\ldots \ldots \ldots \ldots \ldots$. . . . . 24

2.11 Summary of $\mathrm{J}_{\mathrm{i}}$ and $\mathrm{dJ} / \mathrm{da}$ values at $288 \mathrm{C}(550 \mathrm{~F})$ for bimetallic weld region obtained

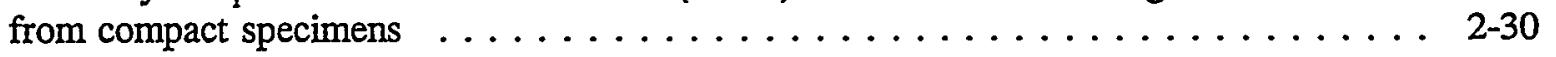

3.1 Key results for two bimetallic weld pipe fracture experiments $\ldots \ldots \ldots \ldots \ldots \ldots$

4.1 Tensile properties at $288 \mathrm{C}(550 \mathrm{~F})$ of the A516 Grade 70 carbon steel pipe, F316 stainless steel safe end, and Inconel 182 SMAW weld metal used in the analyses of the bimetallic weld cold-leg pipe experiment . . . . . . . . . . . 4-2

4.2 Extrapolated power-law $\mathrm{J}_{\mathrm{D}}-\mathrm{R}$ curve constants for quasi-static fusion-line data at $288 \mathrm{C}(550 \mathrm{~F})$ used in fracture analyses $\ldots \ldots \ldots \ldots \ldots \ldots$ 


\section{CONTENTS}

$\underline{\text { Page }}$

4.3 Pipe and crack dimensions used in fracture analyses of Experiment 1.1.1.28 . . . . 4-5

4.4 Comparison of the experimental moment at crack initiation for Experiment 1.1.1.28 with the fracture analyses predictions of the crack initiation moments (using fusion-line $\mathrm{C}(\mathrm{T})$ specimen $\mathrm{J}-\mathrm{R}$ curve data) $\ldots \ldots \ldots \ldots \ldots \ldots \ldots$

4.5 Comparison of the maximum experimental moment for Experiment 1.1.1.28 with the fracture analyses predictions of the maximum moment $\ldots \ldots \ldots \ldots \ldots \ldots$

4.6 Comparison of $\mathrm{J}$ at crack initiation $\left(\mathrm{J}_{\mathrm{i}}\right)$ values from $\eta$-factor analysis for Pipe Experiment 1.1.1.28 with $\mathrm{J}_{\mathrm{i}}$ values from the $\mathrm{C}(\mathrm{T})$ specimens machined from the different materials that make up the bimetallic weldment $\ldots \ldots \ldots \ldots \ldots \ldots \ldots \ldots \ldots \ldots$

5.1 Comparison of quasi-static tensile yield and ultimate tensile strengths at $288 \mathrm{C}(550 \mathrm{~F})$ of the three materials that make up the bimetallic weld evaluated in this program . . . . 5-1

5.2 Comparison of $J$-values at crack initiation $\left(\mathrm{J}_{\mathrm{i}}\right)$ at $288 \mathrm{C}(550 \mathrm{~F})$ for three of the materials that make up the bimetallic weld evaluated in this program $\ldots \ldots \ldots \ldots \ldots$

5.3 Comparison of the maximum experimental moments divided by Net-Section-Collapse (NSC) predicted moments for the three cold-leg pipe experiments $\ldots \ldots \ldots \ldots \ldots \ldots$ 
Executive Summary

\section{EXECUTIVE SUMMARY}

In both BWRs and PWRs there are many locations where carbon steel pipes or components are joined to austenitic pipes or components with a bimetallic weld. The objective of the research described in this report was to assess the accuracy of current pipe fracture analyses for the case of a crack along a carbon steel to austenitic weld fusion line. This work was conducted as Task 3 of the NRC's Short Cracks in Piping and Piping Welds Research Program.

The bimetallic welds evaluated in this program were obtained as part of the Degraded Piping Program from a cancelled Combustion Engineering nuclear power plant. The welds joined sections of the carbon steel cold-leg piping system to stainless steel safe ends that were to be welded to stainless steel pump housings. The carbon steel pipe material was A516 Grade 70. The safe ends were fabricated from SA182 F316 stainless steel (forged TP316 stainless steel). The welds were fabricated by first buttering the beveled end of the carbon steel pipe with an ENiCrFe-3 (Inconel 182) electrode. The welds joining the buttered pipes and the stainless steel safe ends were then completed using a shielded-metal-arc weld process, using Inconel 182 weld rod. Several such welds in the nominal 914$\mathrm{mm}$ (36-inch) diameter by 76-mm (3.0-inch) thick pipe were available.

To achieve the program objective, material property data and data from a large diameter pipe fracture experiment were developed to assess current analytical methods. The material property data developed included longitudinal tensile data from specimens machined from the various parts of the pipe weldment as well as data from compact (tension), C(T), tests with cracks located along the carbon steel to austenitic weld fusion line to determine the fracture toughness of the fusion line. The large diameter pipe experiment evaluated a circumferential through-wall crack along the bimetallic weld fusion line subjected to bending at $288 \mathrm{C}(550 \mathrm{~F})$. The various analysis methods were then compared with the pipe experimental data.

The major conclusion was that the fracture behavior of the bimetallic fusion line tested in this program could be predicted with reasonable accuracy using the strength and toughness properties of the carbon steel pipe material in conjunction with conventional elastic-plastic fracture mechanics analysis. This is believed to be due to: (1) the fusion line toughness, evaluated in $C(T)$ specimen tests, being slightly higher than the toughness of the carbon steel base metal, (2) the Inconel weld metal being higher strength than the carbon steel base metal allowing the crack to grow more in the carbon steel than in the Inconel 182 weld metal, and (3) the higher strength Inconel 182 weld metal may be shielding some of the plastic strains between the crack section and the lower strength stainless steel safe end on the other side of the weld. Consequently, the carbon steel base metal strength properties were more appropriate to use in the simple pipe fracture analyses.

One point that should be emphasized is that the data presented in this report, and the conclusions drawn from these data, are applicable only to this one class of bimetallic welds, i.e., a low strength carbon steel pipe welded to a stainless steel safe end using an Inconel weld procedure. The fracture behavior of other classes of bimetallic welds, made up of different material systems, may not be the same. For instance, for bimetallic welds associated with low alloy ferritic steel nozzle forgings, the strength and toughness properties of the various materials may be such that the crack will tend to grow in the weldment. In addition, if the bimetallic weld was made with stainless steel buttering 
rather than Inconel, then the crack may grow into a softer, carbon-depleted, region near the heataffected-zone of the carbon steel material. In such cases, the fracture moments may be less than would be predicted using the carbon steel pipe properties in conjunction with conventional elasticplastic fracture mechanics analysis methods. 


\section{ACKNOWLEDGMENTS}

This work was supported by the United States Nuclear Regulatory Commission through the Electrical, Materials and Mechanical Engineering Branch, Division of Engineering Technology of the Office of Nuclear Regulatory Research under Contract No. NRC-04-90-069. Mr. Allen Hiser and Mr. Mike Mayfield have been the NRC program managers throughout the course of this program.

We would like to thank Drs. J. Joch and J. Zdárek of NRI-Rez for release of their bimetallic weld $\mathrm{J}-\mathrm{R}$ curve data for comparison to data in this effort.

We would like to thank others at Battelle who have helped in these efforts. Technicians who have contributed include: Mr. J. Anthony, Mr. E. Blakesley, Mr. R. Gertler, Mr. P. Held, Mr. P. Mincer, Mr. M. Oliver, and Mr. D. Shoemaker. We also would like to recognize Mrs. V. Kreachbaum, Mrs. B. Blanton, Ms. B. Fuller, Ms. C. Keels, and Ms. A. Armitage for their assistance in preparing this report and Dr. A. Hopper and Mr. K. Dufrane for editorial assistance. 

3 


\section{NOMENCLATURE}

\section{SYMBOLS}

a

$a_{i}$

b

c

$c_{0}$

$\mathrm{C}_{1}$

$\mathrm{C}_{\mathrm{m}}$

D

E

F

$\mathrm{h}$

I

$\mathrm{J}$

$\mathrm{J}_{\mathrm{D}}$

$\mathrm{J}_{\mathbf{i}}$

$\mathrm{J}_{\mathrm{Ic}}$

$J_{M}$

$\mathrm{J}_{\mathrm{e}}$

$\mathrm{J}_{\mathrm{p}}$

$\mathrm{J}_{\text {Total }}$

L
Crack length

Initial crack length

Half the remaining ligament

Half of the circumferential crack length

Initial half crack length

Coefficient in J-R curve pure power-law equation

Machine compliance

Nominal pipe diameter

Young's modulus

Function used in elastic stress intensity factor

Factor used in $\eta$-factor approach

Moment of inertia

J-integral fracture parameter

Deformation $\mathrm{J}$.

J-integral at crack initiation, but not necessarily a valid $\mathrm{J}_{\mathrm{Ic}}$ by ASTM E813-89

$\mathrm{J}$ at crack initiation under Mode I loading

Modified J integral of Ernst

Elastic component of J-integral

Plastic component of J-integral

Total J, elastic plus plastic components of $\mathrm{J}$

Inner span in four-point bend experiment 


\section{Nomenclature}

M

$\mathrm{m}$

n

$\mathbf{P}$

$\mathrm{R}_{\mathrm{m}}$

t

$\mathrm{U}$

$\mathrm{U}_{0}$

$\mathrm{V}_{2}$

W

$\mathrm{y}$

Z

$\alpha$

$\Delta$

$\Delta_{\mathrm{pl}}$

$\Delta_{\mathrm{EL}}^{\mathrm{NC}}$

$\Delta_{\mathrm{EL}}^{\mathrm{C}}$

$\Delta_{\mathrm{EL}}^{\mathrm{M}}$

$\epsilon$

$\epsilon_{\mathrm{o}}$

$\gamma$

$\phi$
Moment

Exponent used to fit J-resistance curve

Ramberg-Osgood strain-hardening exponent

Tension load in $\mathrm{C}(\mathrm{T})$ test, or the total applied load in a four-point bend experiment

Mean pipe radius

Thickness of pipe wall

d-c electric potential

Value of $\mathrm{U}$ at crack initiation

Compliance function in GE/EPRI analysis

Specimen width

Half the spacing of the voltage probes for a $C(T)$ test

Outer span in a four-point bend experiment

Ramberg-Osgood parameter

Pipe displacement at the load point

Plastic load-line displacement; total

Elastic component of displacement of the uncracked pipe

Elastic component of displacement due to the crack

Elastic component of displacement due to the machine compliance

Strain

Reference strain, $\sigma_{0} / \mathrm{E}$

Factor used in $\eta$-factor analysis

Half rotation of pipe 
$\eta$

$\theta$

$\sigma$

$\sigma_{\mathrm{f}}$

$\sigma_{0}$

$\sigma_{\mathrm{u}}$

$\sigma_{\mathbf{y}}$

2.

ASME

ASTM

BWR

CE

CMOD

CS

CTOA

$\mathrm{C}(\mathrm{T})$

CVN

d-c EP

DP 3 II, DP2

DPH

DPZP

EDM
Geometric factor used in J-integral analysis

Half-crack angle

Stress

Flow stress

Reference stress

Ultimate stress

Yield stress
American Society of Mechanical Engineers

American Society for Testing and Materials

Boiling Water Reactor

Combustion Engineering

Crack-mouth-opening displacement

Carbon steel

Crack-tip-opening angle

Compact (tension) specimen

Charpy V-notch

Direct-current electric potential

Degraded Piping Program - Phase II

Diamond Pyramid Hardness

Dimensionless Plastic-Zone Parameter (analysis)

Electric discharge machining 
EPRI

FC

FM

GE

GE/EPRI

HAZ

HDR

IPIRG-1

J-R

$\mathrm{J}_{\mathrm{D}}-\mathrm{R}$

LBB

LBB.ENG2

LBB.GE

LBB.NRC

L-C

L-R

LLD

MEA

NRC

NRCPIPE

NRI

NSC
Electric Power Research Institute (U.S.)

Fatigue crack

Frequency modulated

General Electric

J-estimation scheme developed at GE for EPRI

Heat-affected zone

Heissdampfreaktor (an experimental reactor facility in Germany)

First International Piping Integrity Research Group

J-resistance curve

Deformation theory J-resistance curve

Leak-before-break

Circumferential TWC analysis method developed at Battelle

Circumferential TWC analysis method developed at Battelle

Circumferential TWC analysis method developed at NRC-NRR

Longitudinal-circumferential orientation (direction of circumferential through-wall crack growth around pipe circumference)

Longitudinal-radial orientation (direction of circumferential surface crack growing through the thickness)

Load-line displacement

Materials Engineering Associates

Nuclear Regulatory Commission

PC computer program for circumferential TWC analyses

Nuclear Research Institute (Rez-Republic of Czech)

Net-Section-Collapse (analysis) 
PC

PIFRAC

PWR

ROFIT

R6

SAW

SEM

SMAW

SS

TWC
Personal computer

Piping fracture database

Pressurized water reactor

Computer code to calculate Ramberg-Osgood parameters

A failure assessment criteria developed by Nuclear Electric (United Kingdom)

Submerged-arc weld

Scanning electron microscope

Shielded-metal-arc weld

Stainless steel

Through-wall crack, through-wall-cracked (pipe) 



\section{PREVIOUS REPORTS IN SERIES}

Previous Reports from this Program

"Short Cracks in Piping and Piping Welds," First Semiannual Report, NUREG/CR-4599, Vol. 1, No. 1, March 1991.

"Short Cracks in Piping and Piping Welds," Second Semiannual Report, NUREG/CR-4599, Vol. 1, No. 2, April 1992.

"Short Cracks in Piping and Piping Welds," Third Semiannual Report, NUREG/CR-4599, Vol. 2, No. 1, September 1992.

"Short Cracks in Piping and Piping Welds," Fourth Semiannual Report, NUREG/CR-4599, Vol. 2, No. 2, February 1993.

"Short Cracks in Piping and Piping Welds," Fifth Semiannual Report, NUREG/CR-4599, Vol. 3, No. 1, October 1993.

"Short Cracks in Piping and Piping Welds," Sixth Semiannual Report, NUREG/CR-4599, Vol. 3, No. 2, March 1994.

"Short Cracks in Piping and Piping Welds," Progress Report, NUREG/CR-4599, BMI-2173, Vol. 4, No. 1, April 1995.

"Fracture Behavior of Circumferential Short-Through-Wall-Crack Pipe," NUREG/CR-6235, April 1995.

"Fracture Behavior of Circumferential Short-Surface-Cracked Pipe," NUREG/CR-6298, (in press).

"Effects of Toughness Anisotropy and Combined Loading on Fracture Behavior of Ferritic Nuclear Pipe," NUREG/CR-6299, April 1995.

"Dynamic Crack Instabilities in Nuclear Ferritic Piping at LWR Temperatures and the Role of Dynamic Strain Aging," NUREG/CR-6226, October 1994.

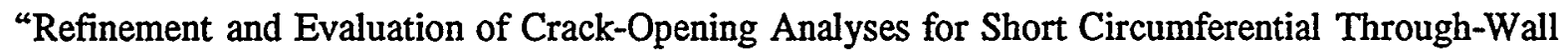
Cracks in Pipes," NUREG/CR-6300, April 1995.

"Probabilistic Pipe Fracture Evaluations for Leak-Rate Detection Applications," NUREG/CR-6004, April 1995.

"Validity Limits in J-Resistance Curve Determination: An Assessment of the $\mathrm{J}_{\mathrm{M}}$ Parameter," NUREG/CR-6264 Volume 1, February 1995. 
Previous Reports in Series

"Validity Limits in J-Resistance Curve Determination: A Computational Approach to Ductile Crack Growth Under Large-Scale Yielding Conditions," NUREG/CR-6264 Volume 2, February 1995.

“Stainless Steel Submerged Arc Weld Fusion Line Toughness," NUREG/CR-6251, April 1995.

\section{Previous Related Documents from NRC's Degraded Piping Program}

“Degraded Piping Program - Phase II," Semiannual Report, NUREG/CR-4082, Vol. 1, Oct. 1984.

“Degraded Piping Program - Phase II," Semiannual Report, NUREG/CR-4082, Vol. 2, June 1985.

“Degraded Piping Program - Phase II," Semiannual Report, NUREG/CR-4082, Vol. 3, March 1986.

“Degraded Piping Program - Phase II," Semiannual Report, NUREG/CR-4082, Vol. 4, July 1986.

“Degraded Piping Program - Phase II," Semiannual Report, NUREG/CR-4082, Vol. 5, Dec. 1986.

“Degraded Piping Program - Phase II," Semiannual Report, NUREG/CR-4082, Vol. 6, April 1988.

“Degraded Piping Program - Phase II," Semiannual Report, NUREG/CR-4082, Vol. 7, March 1989.

“Degraded Piping Program - Phase II," Semiannual Report, NUREG/CR-4082, Vol. 8, March 1989.

"NRC Leak-Before-Break (LBB.NRC) Analysis Method for Circumferentially Through-Wall Cracked Pipes Under Axial Plus Bending Loads,” Topical Report, NUREG/CR-4572, March 1986.

"Elastic-Plastic Finite Element Analysis of Crack Growth in Large Compact Tension and Circumferentially Through-Wall-Cracked Pipe Specimen-Results of the First Battelle/NRC Analysis Round Robin," Topical Report, NUREG/CR-4573 September 1986.

"An Experimental and Analytical Assessment of Circumferential Through-Wall Cracked Pipes Under Pure Bending,” Topical Report, NUREG/CR-4574, June 1986.

"Predictions of J-R Curves With Large Crack Growth From Small Specimen Data," Topical Report, NUREG/CR-4575, August 1986.

"An Assessment of Circumferentially Complex-Cracked Pipe Subjected to Bending," Topical Report, NUREG/CR-4687, September 1986.

"Analysis of Cracks in Stainless Steel TIG Welds," Topical Report, NUREG/CR4806, November 1986.

“Approximate Methods for Fracture Analyses of Through-Wall Cracked Pipes," Topical Report, NUREG/CR-4853, January 1987.

"Assessment of Design Basis for Load-Carrying Capacity of Weld-Overlay Repair," Topical Report, NUREG/CR-4877, February 1987.

“Analysis of Experiments on Stainless Steel Flux Welds," Topical Report, NUREG/CR-4878, February 1987.

"Experimental and Analytical Assessment of Circumferentially Surface-Cracked Pipes Under Bending," Topical Report, NUREG/CR-4872, April 1987. 
Previous Related Documents from NRC's Intermational Piping

Integrity Research Group (IPIRG) Program

"Evaluation and Refinement of Leak-Rate Estimation Models," NUREG/CR-5128, April 1991.

"Loading Rate Effects on Strength and Fracture Toughness of Pipe Steels Used in Task 1 of the IPIRG Program," Topical Report, NUREG/CR-6098, October 1993.

"Stability of Cracked Pipe Under Inertial Stresses--Subtask 1.1 Final Report," NUREG/CR-6233, Vol. 1, August 1994. 


\section{INTRODUCTION}

In piping systems in nuclear power plants, bimetallic welds are used at several locations. Examples from Westinghouse reactors include welds joining the hot and cold legs to the reactor pressure vessel and steam generators. In Combustion Engineering (CE) and Babcock and Wilcox reactors, such welds include ferritic piping to cast stainless steel pump housings, as well as at several nozzle locations, and stainless steel piping to boiling water reactor (BWR) pressure vessel nozzles. Such welds are not only difficult to fabricate, but also to inspect. In addition, due to differential thermal expansion stresses, these welds are subjected to additional service loads that welds between similar metals do not experience. Furthermore, the amount of experimental data currently available to assess the fracture behavior of such piping system welds is somewhat limited. Consequently, a more through evaluation of the fracture behavior of such welds is warranted.

The objective of the work described in this report was to develop material property data and pipe fracture data necessary to assess current analytical engineering estimation schemes to predict the behavior of through-wall cracks in bimetallic welded pipe under bending. In order to satisfy this objective, a program involving material characterization tests, full-scale pipe fracture experiments, and analyses of the pipe experiments was undertaken for one type of bimetallic weld. This report describes these efforts. One point that should be noted is that the data presented in this report are applicable only to this one class of bimetallic welds, i.e., the case where lower strength ferritic piping is welded to a stainless steel safe end using an Inconel welding procedure. The fracture behavior of other classes of bimetallic welds, e.g., stainless steel welds joining stainless steel pipe to low alloy reactor pressure vessel nozzles with higher strength, may be totally different.

The report is broken down into six major sections. This first section is the introduction where the rationale for and objective of this effort are briefly discussed. Section 2 of the report discusses the material characterization efforts. In this section, the results of a series of hardness, tensile, and fracture toughness (Charpy and J-R curve) tests are discussed. Quasi-static tensile tests were conducted on each of the three predominant materials associated with this bimetallic weld, i.e., the carbon steel pipe material, the stainless steel safe-end material, and the Inconel filler weld metal. In addition to the quasi-static tensile tests, quasi-static fracture toughness tests using $C(T)$ specimens were conducted. $C(T)$ specimens were machined and tested for the carbon steel pipe and stainless steel safe-end base materials, as well as for the fusion line at the interface of the carbon steel pipe and the Inconel buttering passes. In addition to these mechanical tests, chemical analyses of the carbon and stainless steel base plates and Inconel 182 weld metal were performed. The results of these chemical analyses are also presented in Section 2.

Section 3 of this report presents the results from the two full-scale, bimetallic weld, pipe fracture experiments conducted as part of this effort. The test pipes were sections of a cold-leg piping system purchased as part of the Degraded Piping Program (Ref. 1.1) from a cancelled CE nuclear power plant. There were a number of bimetallic welds associated with this cold-leg piping system. The welds evaluated in this program were the bimetallic welds used to join the carbon steel cold-leg pipe to stainless steel safe ends, which were then to be welded to a stainless steel pump housing on one of the reactor coolant pumps. In addition, as part of this overall piping system, there were a number of other bimetallic welds used to join the ferritic safety injection nozzles, which are attached to the 
cold-leg piping system, to the stainless steel safety-injection-nozzle safe ends, which in turn were to be welded to the stainless steel safety-injection-line piping system. (The assessment of the fracture behavior of these safety-injection-nozzle bimetallic welds was not in the scope of work for this program.) The cracks for the two cold-leg bimetallic weld pipe fracture experiments conducted as part of this program were located in two of the shop-fabricated bimetallic welds used to join the carbon steel cold-leg pipe to a stainless steel safe end that was to be welded to one of the reactor coolant pump housings. A third identical bimetallic weld from this cold-leg piping system was used for the material characterization efforts. The crack tips for the pipe experiments were machined along the fusion line of the carbon steel pipe to the Inconel buttering passes using a wire cut electricdischarge-machining (EDM) process. The test conditions for the two pipe experiments were nearly identical. The loading conditions for both experiments were quasi-static, four-point bending without internal pipe pressure. The test temperature for both experiments was $288 \mathrm{C}(550 \mathrm{~F})$. The initial through-wall-crack length for both experiments was approximately 37 percent of the pipe

circumference. The second repeat experiment (1.1.1.28) was conducted because no applied load or moment data were obtained for the first experiment due to the fact that certain key data were inadvertently not recorded.

Section 4 of this report presents the results of the limited analyses of the pipe experiment for which valid load and moment data were obtained, i.e., Experiment 1.1.1.28. The analysis efforts included: (1) comparing the moments at crack initiation and maximum moment with available fracture prediction analyses, and (2) calculating a J-R curve for the pipe experiment and comparing this pipe experiment J-R curve with the J-R curves from the $C(T)$ specimen tests. The fracture prediction analyses evaluated as part of this effort included: (a) the Net-Section-Collapse (NSC) analysis, (b) the Dimensionless-Plastic-Zone-Parameter (DPZP) analysis, (c) the GE/EPRI, LBB.ENG2, LBB.NRC, LBB.GE, and Paris/Tada J-estimation scheme analyses, (d) the R6 Revision 3 Option 1 analysis, and (e) the ASME Section XI flaw evaluation criteria for austenitic and ferritic piping. The J-R curve from the pipe experiment was calculated using the $\eta$-factor method using the load-displacement-crack growth data for Experiment 1.1.1.28. Further details of each of these analysis methods are provided in Section 4.

Section 5 presents a discussion of the key results from the material characterization efforts, the pipe fracture experiments, and the analysis efforts conducted as part of this effort. In addition, as part of this Discussion Section, potential differences in the fracture behavior of different classes of bimetallic welds, i.e., different material combinations, are discussed.

The report concludes with a summary and conclusion section in Section 6 .

\subsection{References}

1.1 Wilkowski, G. M. and others, "Degraded Piping Program--Phase II, Summary of Technical Results and Their Significance to Leak-Before-Break and In-Service Flaw Acceptance Criteria," March 1984-January 1989, NUREG/CR-4082, Volume 8, March 1989. 


\section{MATERIAL CHARACTERIZATION RESULTS}

In this section of the report, the results from the material characterization efforts are discussed. Data are presented for the bimetallic weld region as well as for the carbon steel piping and the stainless steel safe-end materials.

\subsection{Background}

The bimetallic weld evaluated in this program was obtained as part of the Degraded Piping Program (Ref. 2.1). The weld was part of a section of the cold-leg piping system from a cancelled Combustion Engineering (CE) nuclear power plant. The weld joined the ferritic cold-leg pipe to a stainless steel safe end, which in turn was to be welded to the pump housing of one of the reactor coolant pumps. The bimetallic weld was fabricated by first buttering the carbon steel pipe with Inconel 182 weld rod and then welding the buttered pipe to the SA182 F316 forged stainless steel safe end using a shielded-metal-arc-weld (SMAW) process, see Figure 2.1. The filler metal for the SMAW process was Inconel 182. The carbon steel pipe material was A516 Grade 70.

As noted earlier, other classes of bimetallic welds can be found in nuclear plants. Examples include the cases where stainless steel piping is welded to relatively high strength reactor pressure vessel nozzle material, i.e., higher strength in relation to the A516 Grade 70 pipe material. In addition, other materials besides the Inconel 182 are sometimes used to butter the carbon steel material and complete the weld process. These materials include E308 and E309 stainless steel weld rod. Potential differences in the fracture behavior for these different classes of bimetallic welds, i.e., different material combinations, will be discussed in Section 5 of this report.

The remainder of this section of the report describes the material characterization experiments carried out on the different material components of the bimetallic weld evaluated in this program. These data were used in the analyses of the pipe experiments discussed in Section 4 of this report. The carbon steel pipe data were developed in earlier programs in References 2.1 and 2.2. The new data were incorporated into a Version 3.0 of the NRC's Piping and Fracture Mechanics Database (PIFRAC) (Ref. 2.2).

\subsection{Material Description}

The material results reported in this section of the report were obtained using specimens fabricated from: (1) the carbon steel base pipe, (2) the stainless steel safe end, (3) the bimetallic weld joining the carbon steel pipe to the stainless steel safe end, and (4) the fusion line region at the carbon steel pipe/Inconel 182 interface. These materials were obtained as part of the Degraded Piping Program 


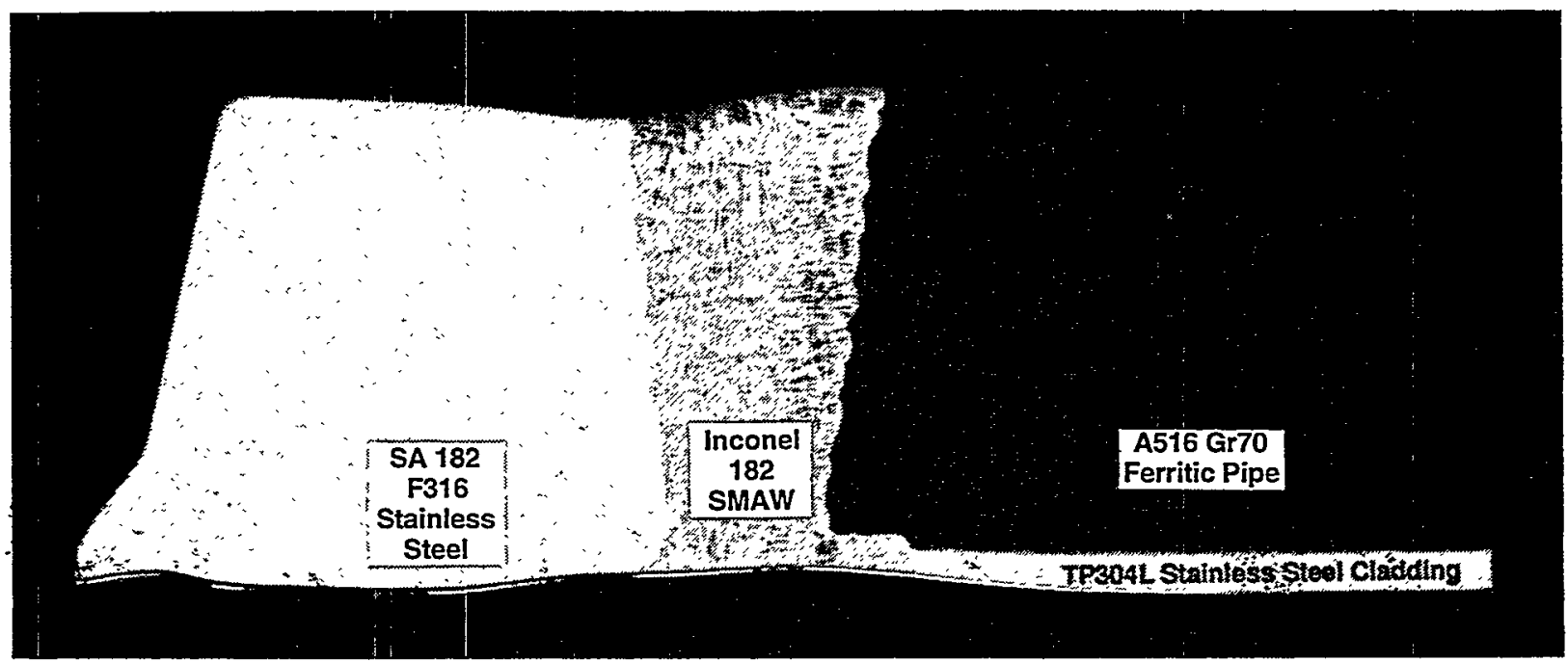

Figure 2.1 Cross section of bimetal weld evaluated in this program showing various materials that make up the weldment

(Ref. 2.1) from a cancelled CE plant ${ }^{(\mathrm{a})}$. The pipe was a 914-mm (36-inch) diameter, carbon steel pipe made from A516 Grade 70, with a wall thickness of approximately $86 \mathrm{~mm}$ (3.4 inch). This wall thickness included a 6.3-mm (0.25-inch) thick TP304L stainless steel clad explosively bonded to the inside surface, see Figure 2.1. This carbon steel pipe was welded to an SA182 F316 stainless steel safe end. The wall thickness of the safe end was approximately $81 \mathrm{~mm}(3.2 \mathrm{inch})$. The weld was made using a shielded-metal-arc weld (SMAW) process using Inconel 182 filler metal after first buttering the beveled edge of the carbon steel pipe with an Inconel 182 welding rod.

(a) The pipe was originally received in seven sections. The different sections were all given their own Battelle identification numbers, i.e., DP2-F33 through DP2-F39. Material specimens for both weld metal and base metal tests were removed from several of these pipe sections, which accounts for the differences in the specimen numbers in this report. 
In the process of removing Charpy specimens from the bimetallic weld fusion line, it was discovered that one of the longitudinal slices from which the specimens were to be machined contained the repair welds that are seen in Figure 2.2. From the etching pattern on the surface of the cross section, it is evident that the weldment had been gouged from both the inside and the outside and additional filler metal added. Because the repair welds were not immediately adjacent to the carbon-steel/weld-metal fusion line (i.e., adjacent to the planned fracture plane), it was assumed that the repair weld would not significantly affect the material properties in the region of interest.

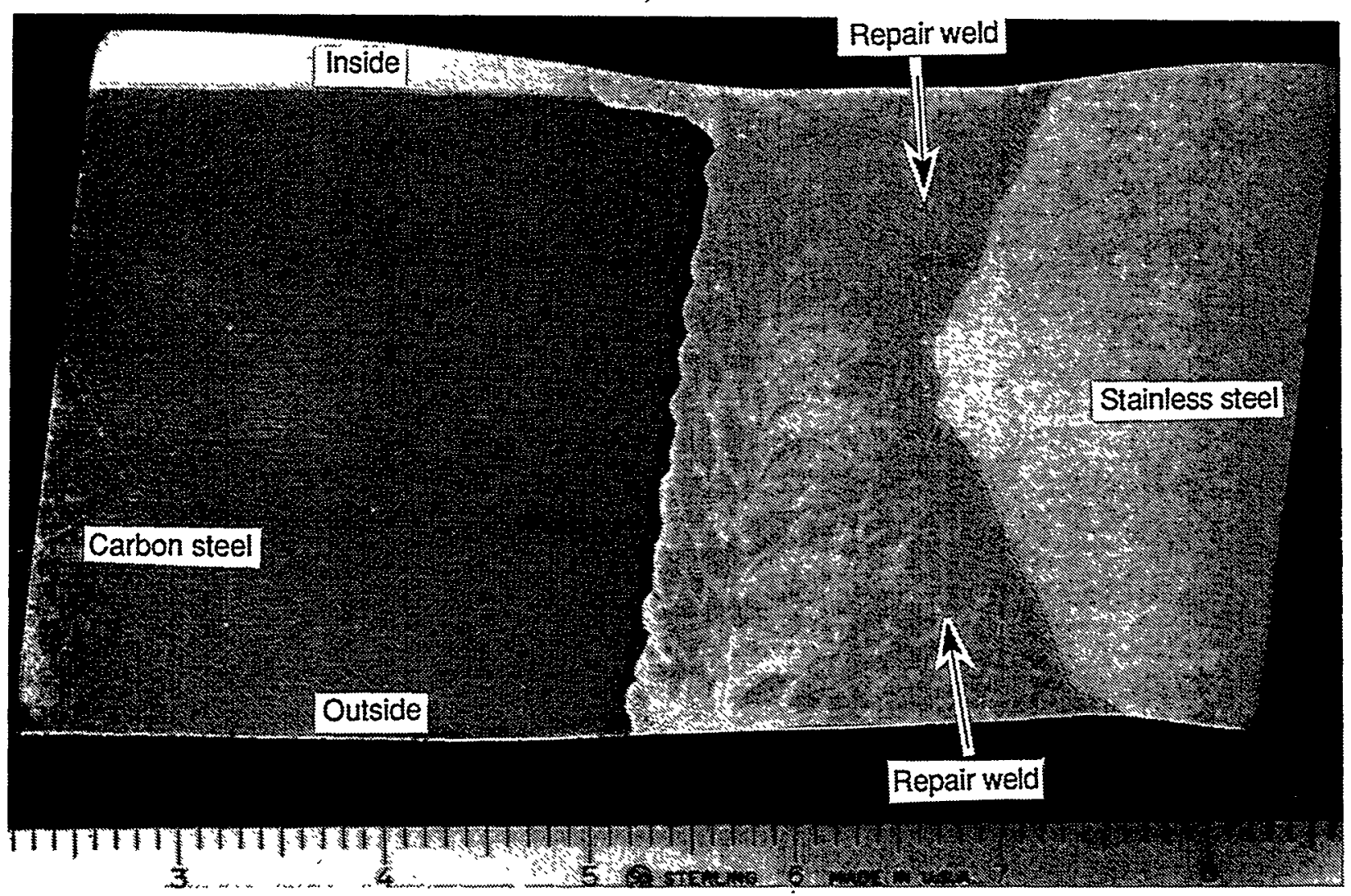

Figure 2.2 Bimetallic weld (DP2-F33W) showing repair weld 


\subsection{Chemical Composition}

Table 2.1 gives the composition of the carbon steel pipe and the stainless steel safe end, as determined by mass spectroscopy by the Worthington Steel Company of Columbus, Ohio. The filler metal was too high in nickel to be analyzed by their equipment. Consequently, Energy Dispersive Spectroscopy was used to measure the chemical composition of the weld metal.

Table 2.1 Chemical composition of base materials and Inconel weld metal in bimetallic weld DP2-F33W

\begin{tabular}{cccc}
\hline & \multicolumn{3}{c}{ Percent by Weight } \\
\hline Element & $\begin{array}{c}\text { A516 Grade 70 } \\
\text { Pipe }\end{array}$ & $\begin{array}{c}\text { SA182 F316 } \\
\text { Safe End }\end{array}$ & $\begin{array}{c}\text { Inconel 182 } \\
\text { Weld }\end{array}$ \\
\hline $\mathrm{C}$ & 0.25 & 0.01 & - \\
$\mathrm{Mn}$ & 0.90 & 1.3 & 6.37 \\
$\mathrm{P}$ & 0.011 & 0.03 & - \\
$\mathrm{S}$ & 0.009 & $<0.01$ & - \\
$\mathrm{Si}$ & 0.21 & 0.63 & 0.70 \\
$\mathrm{Cu}$ & 0.073 & 0.32 & - \\
$\mathrm{Sn}$ & 0.005 & 0.01 & - \\
$\mathrm{Ni}$ & 0.072 & 12.2 & 73.39 \\
$\mathrm{Cr}$ & 0.099 & 16.1 & 15.86 \\
$\mathrm{Mo}$ & 0.027 & 2.1 & - \\
$\mathrm{Al}$ & 0.035 & 0.02 & - \\
$\mathrm{V}$ & 0.000 & 0.06 & - \\
$\mathrm{Nb}$ & 0.000 & 0.04 & 2.01 \\
$\mathrm{Zr}$ & 0.000 & 0.001 & - \\
$\mathrm{Ti}$ & 0.000 & 0.005 & - \\
$\mathrm{B}$ & 0.0003 & 0.0002 & - \\
$\mathrm{Ca}$ & 0.0000 & 0.0013 & - \\
$\mathrm{Co}$ & 0.005 & 0.34 & - \\
$\mathrm{Pb}$ & 0.00 & $\mathrm{~N} . \mathrm{D}$. & - \\
$\mathrm{Fe}$ & $\mathrm{Balance}$ & 66.4 & 1.67 \\
\hline & & &
\end{tabular}




\subsection{Hardness Data}

Figure 2.3 shows the results of hardness traverses (Rockwell B) superposed on a sketch of the weld cross section, while Figure 2.4 is a graph of hardness versus distance from the fusion line. Notice that the weld was harder by fifteen to twenty Rockwell B units than the carbon steel base metal, indicating that the weld would have an estimated ultimate strength 160 to $240 \mathrm{MPa}$ (23 to $35 \mathrm{ksi}$ ) greater than that of the carbon steel. Finer detail on hardness was obtained with Knoop microhardness traces. These traces revealed a slight softening (less than five percent) in the carbon steel heat-affected zone extending for about 0.1 to $0.2 \mathrm{~mm}(0.004$ to 0.008 inch) from the fusion line. This softening was not believed to affect the fracture behavior of the weldment significantly.

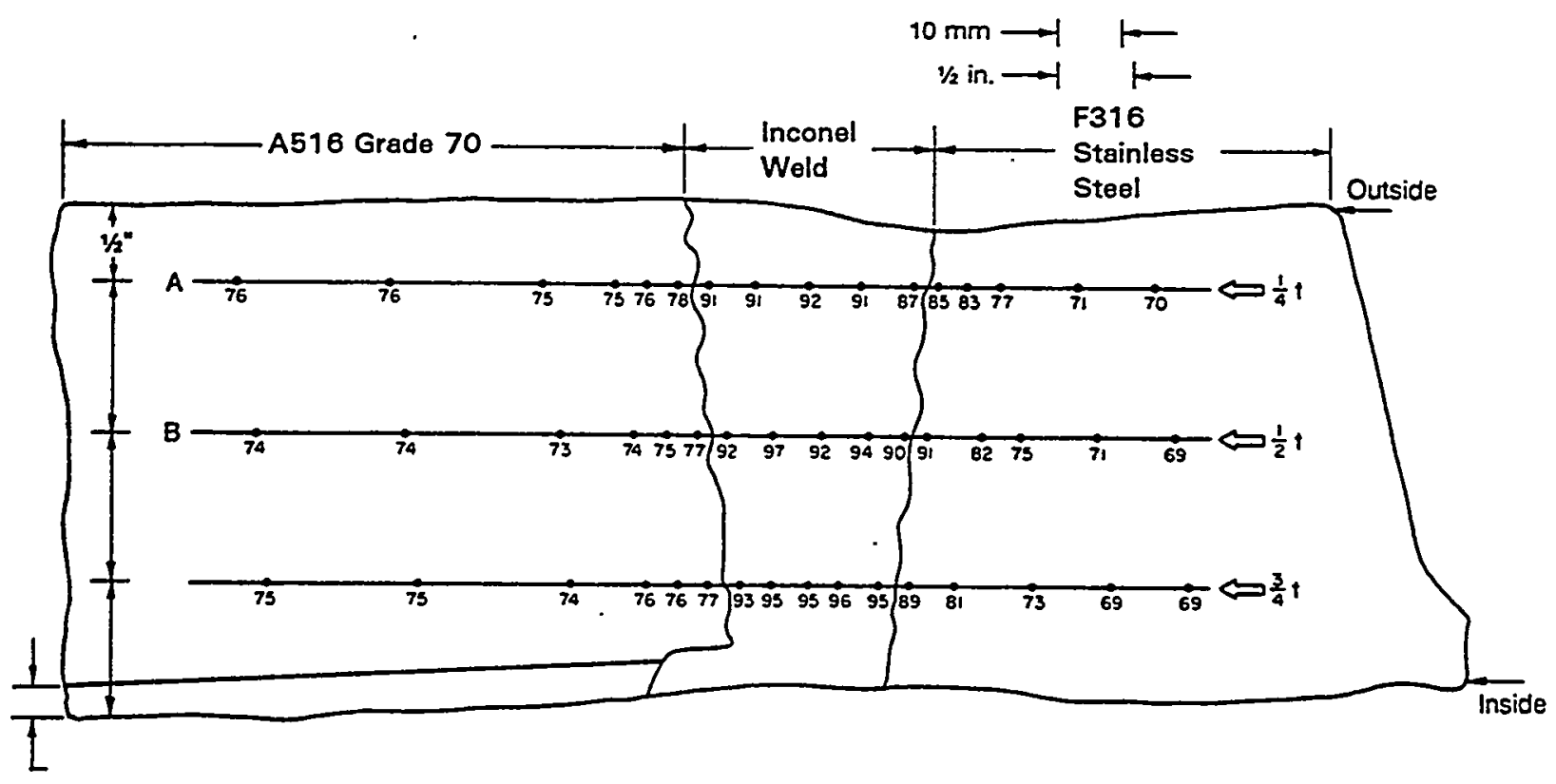

Figure 2.3 Hardness map of bimetallic weld (Pipe DP2-F33) 

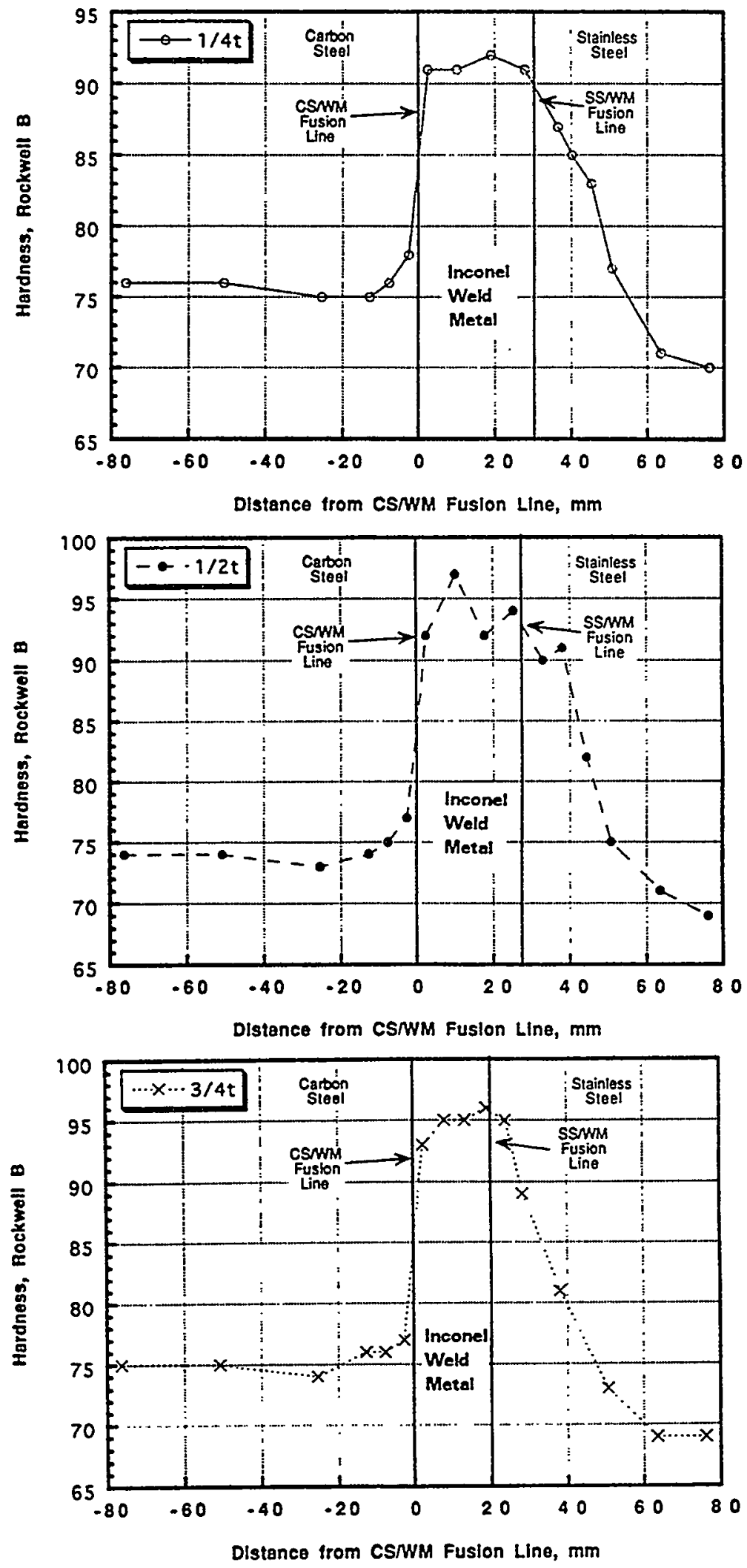

Figure 2.4. Hardness traverses across bimetallic weld fusion lines 


\subsection{Tensile Data}

In this section of the report, the results from the tensile tests for the carbon steel pipe, the stainless steel safe end, and the stainless steel weld region are presented.

\subsubsection{Carbon Steel Base Metal Tensile Properties}

As part of an earlier program (Ref. 2.2.) quasi-static tensile tests on the carbon steel pipe material were conducted at Materials Engineering Associates (MEA), using round-bar specimens having threaded ends. Each specimen had a 12.8-mm (0.505-inch) diameter reduced section and were oriented such that the tensile axes were parallel to the pipe axis. An extensometer of 25.4-mm (1.0-inch) gage length was used to measure axial strain. The tensile specimens were removed from three different locations: (1) near the inside diameter, (2) at midwall, and (3) near the outside diameter. Tensile properties at the three locations are given in Table 2.2.

Figure 2.5 shows the engineering stress-strain curves and Figure 2.6 shows the true stress-strain curves up to the onset of necking at $288 \mathrm{C}(550 \mathrm{~F})$ for this carbon steel pipe material. The true stress-strain curves were computed by assuming that the material in the gage section maintained constant volume.

Table 2.2 Tensile properties of A516 Grade 70 Pipe DP2-F34 in the Iongitudinal direction (Ref. 2.2)

\begin{tabular}{|c|c|c|c|c|c|}
\hline $\begin{array}{l}\text { Spec. } \\
\text { Ident. } \\
\text { No. }\end{array}$ & $\begin{array}{c}\text { Temperature, } \\
\text { C (F) }\end{array}$ & $\begin{array}{l}\text { 0.2-Percent } \\
\text { Offset Yield } \\
\text { Strength, } \\
\text { MPa (ksi) }\end{array}$ & $\begin{array}{l}\text { Ultimate } \\
\text { Tensile } \\
\text { Strength, } \\
\text { MPa (ksi) }\end{array}$ & $\begin{array}{l}\text { Elongation, } \\
\text { Percent in } \\
50.8 \mathrm{~mm} \\
(2.0 \text { inch })\end{array}$ & $\begin{array}{c}\text { Area } \\
\text { Reduction, } \\
\text { Percent }\end{array}$ \\
\hline$B L-12^{(a)}$ & $288(550)$ & $230(33.4)$ & $485(70.3)$ & 32.5 & 64.4 \\
\hline $\mathrm{BL}-\mathrm{M} 2^{(\mathrm{b})}$ & $288(550)$ & $210(30.5)$ & 510 (73.9) & (c) & (c) \\
\hline $\mathrm{BL}-02^{(\mathrm{d})}$ & $288(550)$ & $264(38.3)$ & 494 (71.7) & 30.2 & 63.7 \\
\hline
\end{tabular}
(a) Near the inside diameter
(b) At midwall
(c) Not reported by MEA
(d) Near the outside diameter 


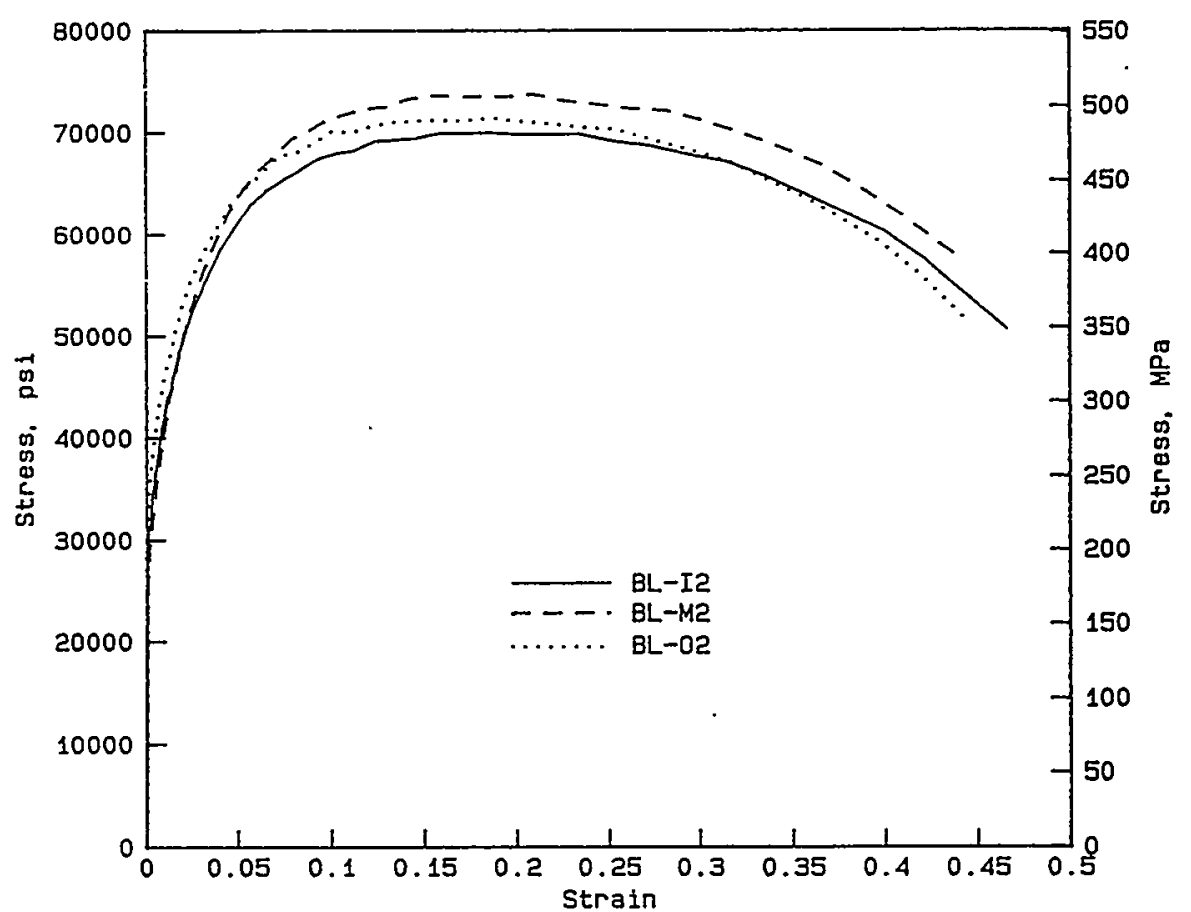

Figure 2.5 Engineering stress-strain curves at $288 \mathrm{C}$ (550 F) for A516 Grade 70 carbon steel pipe (DP2-F34), from Reference 2.2

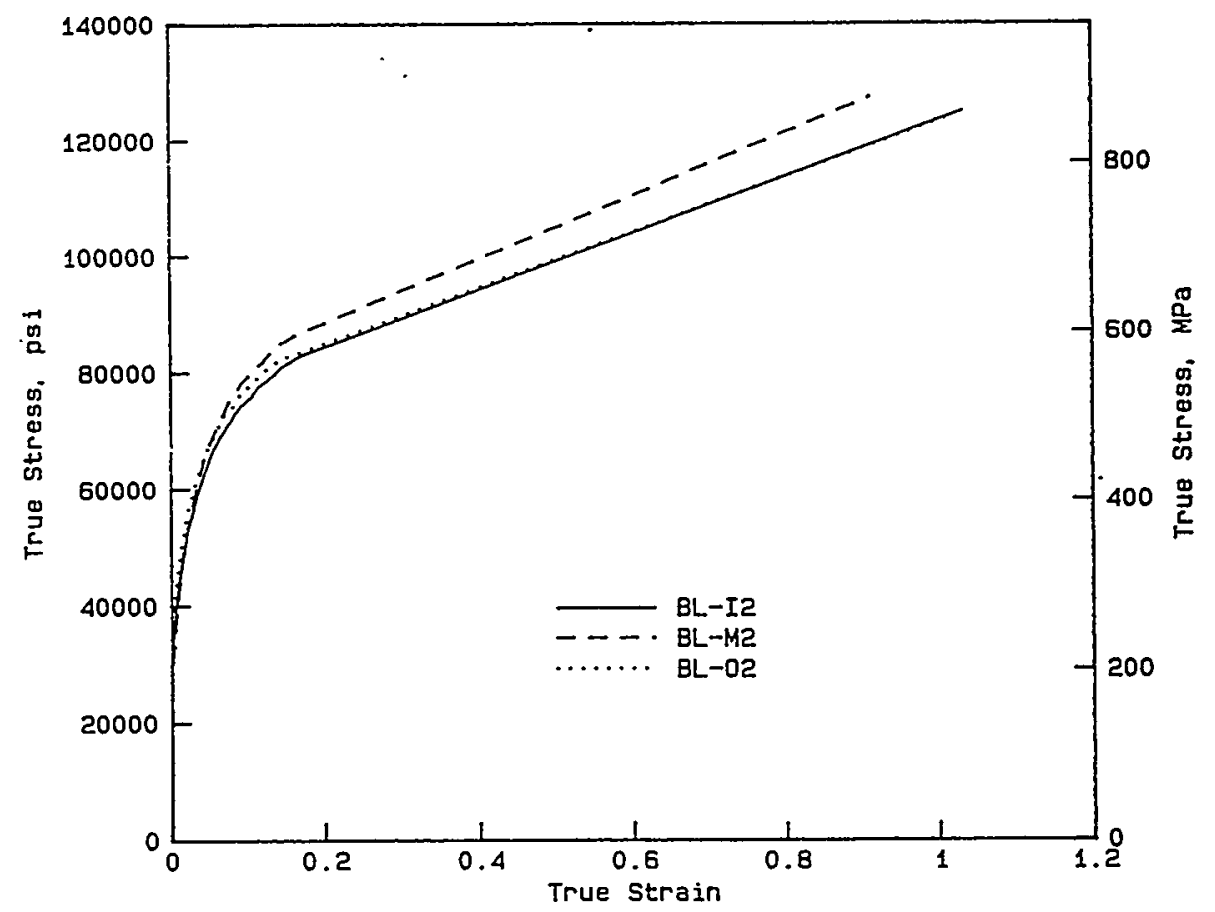

Figure 2.6 True stress-strain curves at 288 C (550 F) for A516 Grade 70 carbon steel pipe (DP2-F34), from Reference 2.2 


\subsubsection{Stainless Steel Safe-End Tensile Properties}

Quasi-static tensile tests on the stainless steel safe end material were conducted at Battelle, using round-bar specimens having threaded ends. Each specimen had a 6.35-mm $(0.25$-inch) diameter reduced section and were oriented such that the tensile axes were parallel to the pipe axis. An extensometer of $25-\mathrm{mm}(1.0$-inch) gage length was used to measure the axial strain. The tensile properties of this stainless steel material are summarized in Table 2.3. Figures 2.7 and 2.8 show the engineering and true stress-strain curves, respectively, for this stainless steel safe end material at $288 \mathrm{C}(550 \mathrm{~F})$.

Table 2.3 Quasi-static tensile properties of SA182 F316 forged stainless steel safe-end material tested at $288 \mathrm{C}(550 \mathrm{~F})$

\begin{tabular}{ccccc}
\hline $\begin{array}{c}\text { Specimen } \\
\text { Number }\end{array}$ & $\begin{array}{c}\text { 0.2 Percent } \\
\text { Yield Strength, } \\
\text { MPa (ksi) }\end{array}$ & $\begin{array}{c}\text { Ultimate Tensile } \\
\text { Strength, } \\
\text { MPa (ksi) }\end{array}$ & $\begin{array}{c}\text { Elongation, Percent in } \\
\text { 25.4 mm (1 inch) }\end{array}$ & $\begin{array}{c}\text { Reduction } \\
\text { in Area, } \\
\text { Percent }\end{array}$ \\
\hline F33SS-T1 & $161(23.3)$ & $414(60.0)$ & 42.2 & 76 \\
F33SS-T2 & $148(21.5)$ & $416(60.3)$ & 44.9 & 76 \\
Average & $157(22.8)$ & $415(60.2)$ & 43.6 & 76 \\
\hline
\end{tabular}

\subsubsection{Inconel Weld Metal Tensile Properties}

As part of this program, threaded end, round bar tensile specimens having a gage diameter of 6.35 $\mathrm{mm}(0.25 \mathrm{inch})$ and a reduced section of $31.8 \mathrm{~mm}(1.25 \mathrm{inch})$ were machined such that the specimen axes were normal to the direction of the weld (i.e., the specimen length is in the axial direction of the pipe). During specimen fabrication, the blanks were etched to ensure that the reduced sections of the specimens contained only the Inconel 182 weld metal.

Quasi-static tensile tests were conducted at $288 \mathrm{C}(550 \mathrm{~F})$ in a servohydraulic machine at a loading rate of $0.5 \mathrm{~mm} / \mathrm{min}(0.02 \mathrm{in} / \mathrm{min})$. Strain was monitored using a 25.4-mm (1-inch) extensometer having spring-loaded ceramic arms that contacted the specimen at each end of the gage length.

Table 2.4 is a summary of the engineering tensile properties of the weld. Specimen F33W-T1 broke outside the gage section. Consequently, the data for that specimen are suspect. The data for only Specimen F33W-T2 were used in the analyses discussed in Section 4 of this report. Figures 2.9 and 2.10 show the engineering and true stress-strain curves, respectively, for this weld metal material at $288 \mathrm{C}(550 \mathrm{~F})$. 


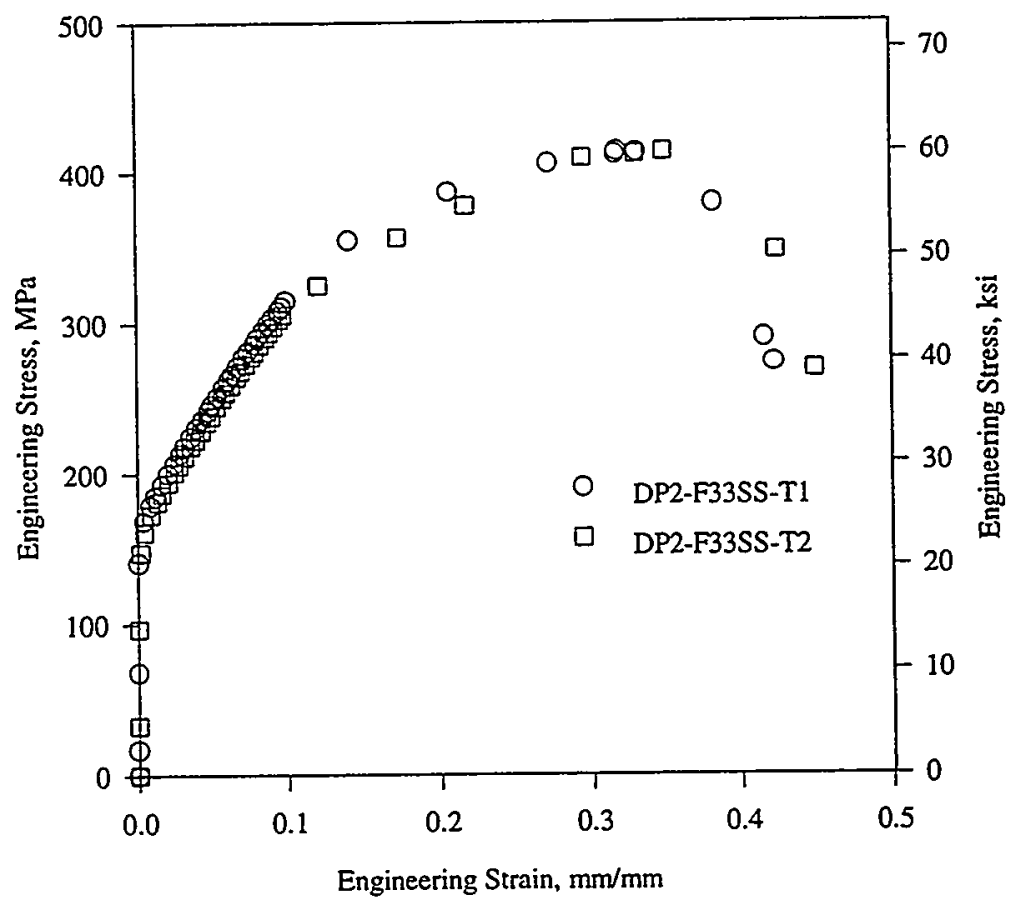

Figure 2.7 Engineering stress-strain curve at $288 \mathrm{C}(550 \mathrm{~F})$ for SA182 F316 stainless steel safe-end material

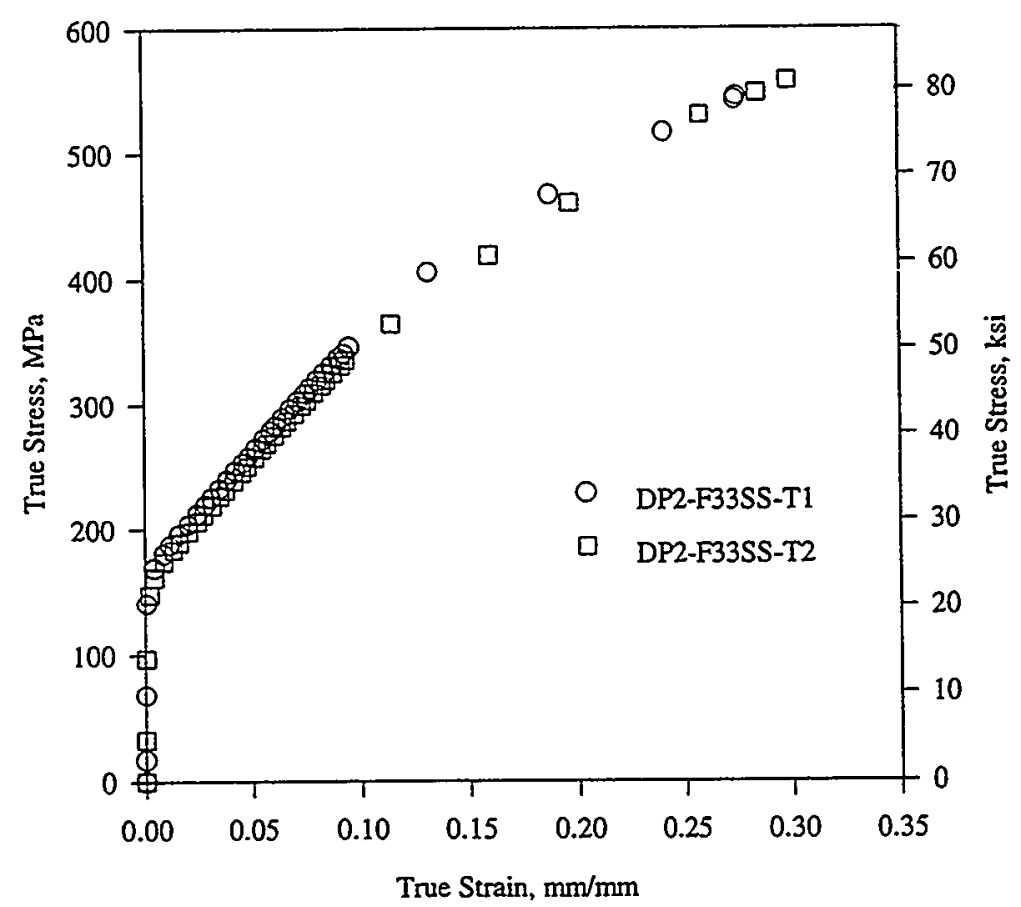

Figure 2.8 True stress-strain curve at $288 \mathrm{C}(550 \mathrm{~F})$ for SA182 F316 stainless steel safe-end material 
Table 2.4 Quasi-static tensile properties of Inconel 182 weld (DP2-F33W) in 914-mm (36-inch) diameter pipe tested at $288 \mathrm{C}(550 \mathrm{~F})$

\begin{tabular}{|c|c|c|}
\hline $\begin{array}{l}\text { Specimen } \\
\text { Number }\end{array}$ & $\begin{array}{c}\text { 0.2-Percent } \\
\text { Offset Yield } \\
\text { Strength, } \\
\text { MPa (ksi) }\end{array}$ & $\begin{array}{l}\text { Ultimate } \\
\text { Tensile } \\
\text { Strength, } \\
\text { MPa (ksi) }\end{array}$ \\
\hline F33W-T1* & $393(57.0)$ & $568(82.4)$ \\
\hline F33W-T2 & $372(54.0)$ & 599 (86.9) \\
\hline
\end{tabular}

* Broke outside the gage section.

\subsection{Charpy V-Notch Impact Test Data}

In this section of the report, the results from a series of Charpy impact tests on the carbon steel pipe and the fusion-line region at the interface of the carbon steel pipe and the Inconel 182 buttering passes are presented.

\subsubsection{Charpy Data from A516 Grade 70 Carbon Steel Base Metal Material}

The Charpy data for the carbon steel base metal were developed as part of an earlier program (Ref. 2.2). Full-size Charpy V-notch (CVN) impact specimens were machined from the carbon steel pipe such that the fracture extended as a through-wall crack in the circumferential direction (L-C orientation). As was the case for carbon steel pipe tensile specimens, the Charpy specimens were machined from three different locations of the pipe wall: (1) near the inside diameter, (2) at midwall, and (3) near the outside diameter. Test temperatures were selected to encompass the ductile/brittle transition region. Test results are summarized in Tables 2.5 through 2.7 for the three different locations. Table 2.5 summarizes the data for the material removed from near the inside pipe surface. Table 2.6 summarizes the data for the material removed from near the mid-wall location. Table 2.7 summarizes the data for the material removed from near the outside pipe surface. 


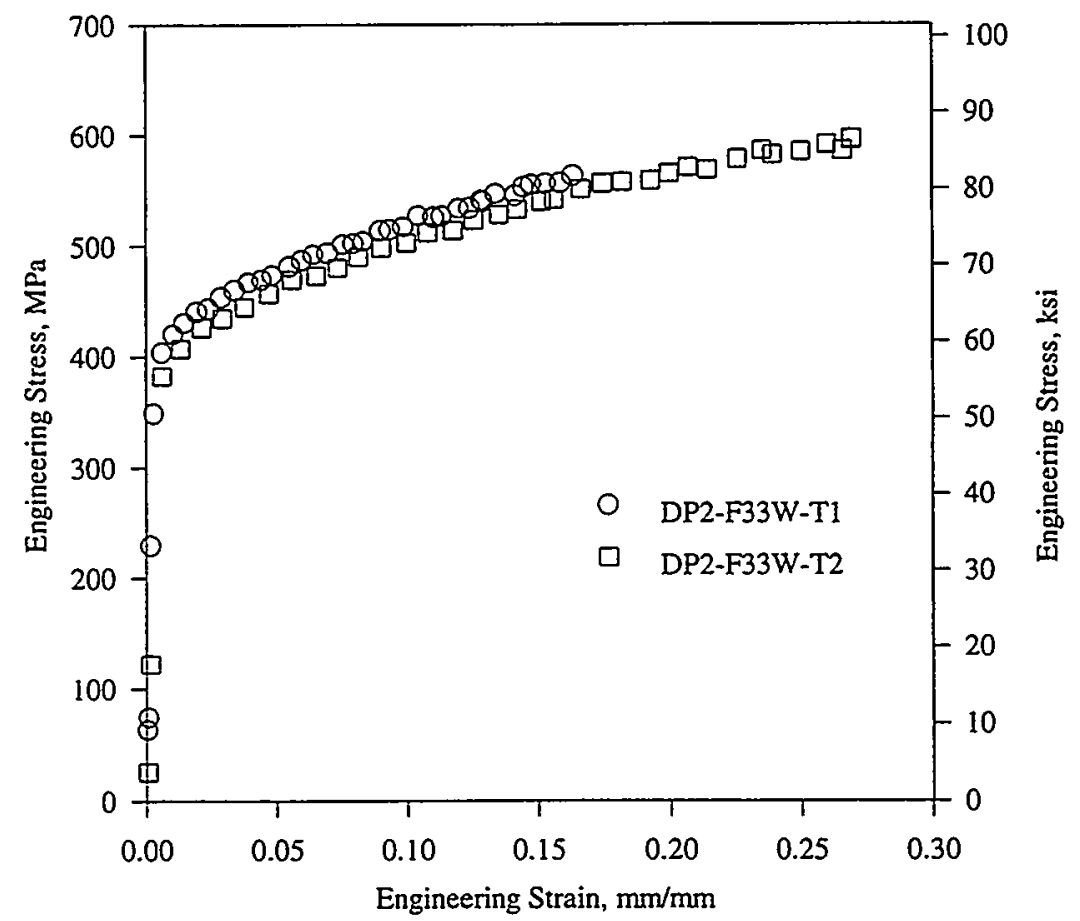

Figure 2.9 Engineering stress-strain curves at $288 \mathrm{C}(550 \mathrm{~F})$ for the Inconel 182 weld material

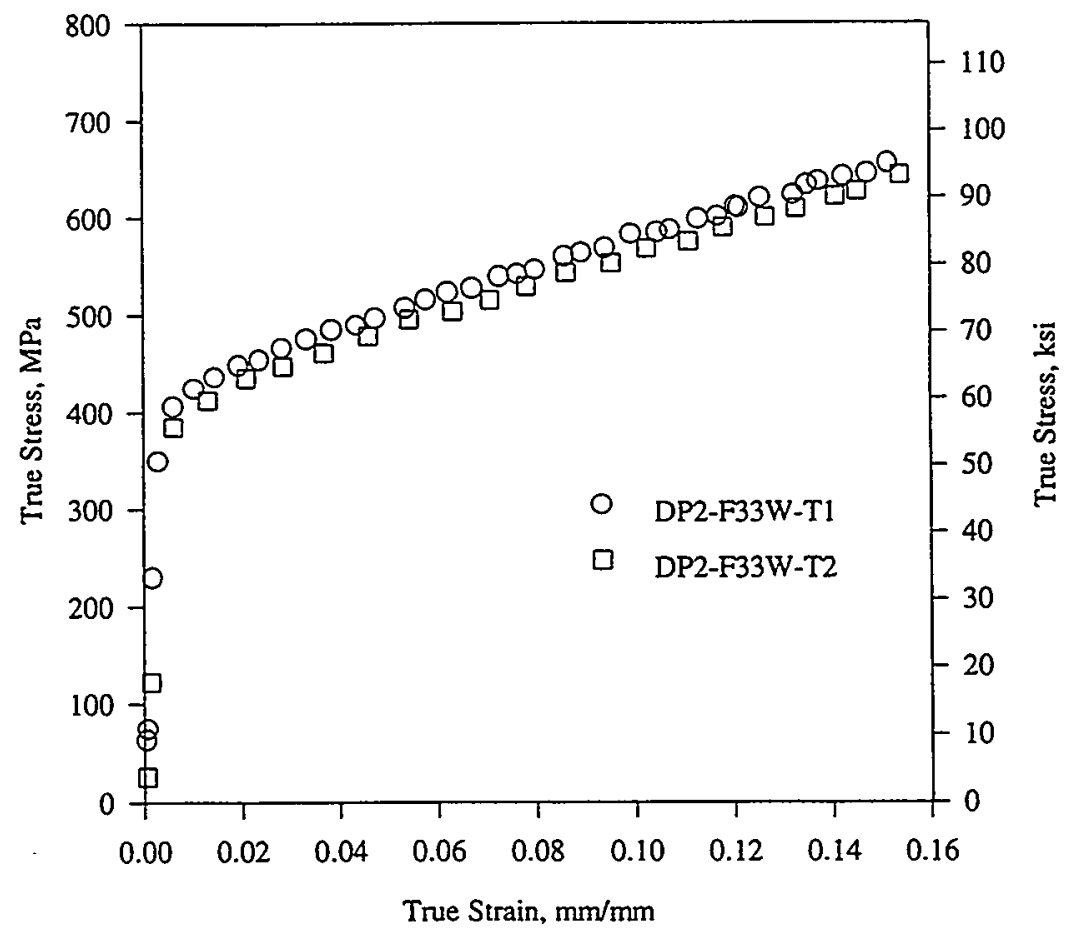

Figure 2.10 True stress-strain curves at $288 \mathrm{C}(550 \mathrm{~F})$ for the Inconel 182 weld material 
Table 2.5 Results of Charpy V-notch impact tests for A516 Grade 70 Pipe DP2-F34 (L-C orientation, near inside pipe surface location) [Specimens were fabricated and tested by Materials Engineering Associates (Ref. 2.2)]

\begin{tabular}{cccc}
\hline $\begin{array}{c}\text { Temperature, } \\
\text { C (F) }\end{array}$ & $\begin{array}{c}\text { Energy, } \\
\text { J (ft-lb) }\end{array}$ & $\begin{array}{c}\text { Laterial Expansion, } \\
\text { mm (inch) }\end{array}$ & $\begin{array}{c}\text { Shear } \\
\text { Area, } \\
\text { percent }\end{array}$ \\
\hline$-51(-60)$ & $7(5)$ & $0.03(0.001)$ & 0 \\
$-40(-40)$ & $8(6)$ & $0.05(0.002)$ & 5 \\
$-18(0)$ & $39(28)$ & $0.30(0.012)$ & 17 \\
$-18(0)$ & $44(32)$ & $0.33(0.013)$ & 17 \\
$4(40)$ & $62(45)$ & $0.48(0.019)$ & 33 \\
$16(60)$ & $72(52)$ & $0.51(0.020)$ & 44 \\
$22(72)$ & $100(72)$ & $0.69(0.027)$ & 55 \\
$22(72)$ & $109(79)$ & $0.79(0.031)$ & 60 \\
$52(125)$ & $163(118)$ & $0.99(0.039)$ & 100 \\
$66(150)$ & $160(116)$ & $0.99(0.039)$ & 100 \\
$93(200)$ & $166(120)$ & $0.99(0.039)$ & 100 \\
$93(200)$ & $160(116)$ & $0.99(0.039)$ & 100 \\
$149(300)$ & $165(119)$ & $0.99(0.039)$ & 100 \\
$149(300)$ & $178(129)$ & $1.02(0.040)$ & 100 \\
$218(425)$ & $216(156)$ & $0.76(0.030)$ & 100 \\
$218(425)$ & $224(162)$ & $0.76(0.030)$ & 100 \\
$288(550)$ & $232(168)$ & $0.69(0.027)$ & 100 \\
$288(550)$ & $210(152)$ & $0.66(0.026)$ & 100 \\
\hline & & & \\
\hline & & 000 & 0 \\
\hline
\end{tabular}


Table 2.6 Results of Charpy V-notch impact tests for A516 Grade 70 Pipe DP2-F34 (L-C orientation, midwall location) [Specimens were fabricated and tested by Materials Engineering Associates (Ref. 2.2)]

\begin{tabular}{cccc}
\hline $\begin{array}{c}\text { Temperature, } \\
\text { C (F) }\end{array}$ & $\begin{array}{c}\text { Energy, } \\
\text { J (ft-lb) }\end{array}$ & $\begin{array}{c}\text { Laterial Expansion, } \\
\text { mm (inch) }\end{array}$ & $\begin{array}{c}\text { Shear Area, } \\
\text { percent }\end{array}$ \\
\hline$-51(-60)$ & $7(5)$ & $0.00(0.000)$ & 0 \\
$-40(-40)$ & $10(7)$ & $0.06(0.0025)$ & 0 \\
$-18(0)$ & $40(29)$ & $0.33(0.013)$ & 17 \\
$-18(0)$ & $46(33)$ & $0.36(0.014)$ & 21 \\
$4(40)$ & $69(50)$ & $0.56(0.022)$ & 50 \\
$16(60)$ & $62(45)$ & $0.48(0.019)$ & 52 \\
$22(72)$ & $83(60)$ & $0.63(0.025)$ & 60 \\
$22(72)$ & $86(62)$ & $0.69(0.027)$ & 55 \\
$52(125)$ & $119(86)$ & $0.89(0.035)$ & 97 \\
$66(150)$ & $124(90)$ & $0.91(0.036)$ & 100 \\
$93(200)$ & $133(96)$ & $0.91(0.036)$ & 100 \\
$93(200)$ & $127(92)$ & $0.89(0.035)$ & 100 \\
$149(300)$ & $122(88)$ & $0.94(0.037)$ & 100 \\
$149(300)$ & $129(93)$ & $0.97(0.038)$ & 100 \\
$218(425)$ & $137(99)$ & $0.89(0.035)$ & 100 \\
$218(425)$ & $138(100)$ & $0.89(0.035)$ & 100 \\
$288(550)$ & $133(96)$ & $0.84(0.033)$ & $0.81(0.032)$ \\
$288(550)$ & $145(105)$ & 00 & 5 \\
\hline
\end{tabular}


Table 2.7 Results of Charpy V-notch impact tests for A516 Grade 70 Pipe DP2-F34 (L-C orientation, near outside pipe surface location) [Specimens were fabricated and tested by Materials Engineering Associates (Ref. 2.2)]

\begin{tabular}{cccc}
\hline $\begin{array}{c}\text { Temperature, } \\
\text { C (F) }\end{array}$ & $\begin{array}{c}\text { Energy, } \\
\text { J (ft-lb) }\end{array}$ & $\begin{array}{c}\text { Laterial Expansion, } \\
\text { mm (inch) }\end{array}$ & $\begin{array}{c}\text { Shear Area, } \\
\text { percent }\end{array}$ \\
\hline$-51(-60)$ & $7(5)$ & $0.00(0.000)$ & 0 \\
$-40(-40)$ & $8(6)$ & $0.03(0.001)$ & 0 \\
$-18(0)$ & $23(17)$ & $0.20(0.008)$ & 11 \\
$-18(0)$ & $39(28)$ & $0.28(0.011)$ & 17 \\
$4(40)$ & $66(48)$ & $0.53(0.021)$ & 36 \\
$16(60)$ & $58(42)$ & $0.46(0.018)$ & 53 \\
$22(72)$ & $83(60)$ & $0.63(0.025)$ & 50 \\
$22(72)$ & $95(69)$ & $0.71(0.028)$ & 62 \\
$66(150)$ & $138(100)$ & $1.02(0.040)$ & 100 \\
$93(200)$ & $160(116)$ & $1.04(0.041)$ & 100 \\
$93(200)$ & $160(116)$ & $1.07(0.042)$ & 100 \\
$149(300)$ & $140(101)$ & $0.99(0.039)$ & 100 \\
$149(300)$ & $144(104)$ & $1.02(0.040)$ & 99 \\
$218(425)$ & $138(100)$ & $1.02(0.040)$ & 100 \\
$218(425)$ & $152(110)$ & $1.02(0.040)$ & 100 \\
$288(550)$ & $135(98)$ & $0.94(0.037)$ & 100 \\
$288(550)$ & $137(99)$ & $0.81(0.032)$ & 100 \\
\hline & & & \\
\hline
\end{tabular}


Figures 2.11 and 2.12 are plots of the Charpy energy and shear area percent, respectively, as a function of temperature. As can be seen in Figure 2.11, the upper shelf energy for the material removed from near the inside pipe surface is higher than that measured for the mid-wall location or the near the outside pipe surface.

\subsubsection{Charpy Data for the Carbon Steel Pipe/Inconel 182 Fusion Line}

As part of this program, fusion-line Charpy specimens were machined with the notch in the L-C orientation in order to simulate the circumferential through-wall-crack growth of the pipe tests. Fabrication of the Charpy specimens was conducted with great care, including frequent chemical etching of the specimen blanks, to ensure that the notches were properly located along the carbon steel/Inconel 182 fusion line of the carbon steel base metal. The specimens were slightly angled to be perpendicular to the fusion line. Table 2.8 shows the results of the Charpy V-notch experiments for the fusion line region. In one of the six specimens (Specimen Number 3), the fracture propagated directly through the cross section (i.e., in the intended fracture plane). This specimen displayed the lowest energy absorption value. Each of the remaining five specimens exhibited pronounced splitting normal to the intended direction of crack propagation. This splitting precluded complete fracture and resulted in the unusually high energy absorption values shown in Table 2.8. Splitting is evident in the scanning-electron microscope (SEM) photographs shown in Figures 2.13 and 2.14 for Specimen Number 4. Figure 2.13 shows that the crack grew in the carbon steel immediately adjacent to the fusion line from Arrow 1 to Arrow 2. It is also evident in Figure 2.13 that the carbon steel was deformed more than the far-stronger weld metal. Figure 2.14 shows that the crack turned away from the fusion line at Arrow 2 and grew toward Arrow 3. Several other splits can be also seen in Figure 2.14.

Table 2.8 Results of Charpy V-notch impact tests at $288 \mathrm{C}(550 \mathrm{~F})$ on specimens from the bimetallic weld fusion line ( $\mathrm{L}-\mathrm{C}$ orientation)

\begin{tabular}{cc}
\hline $\begin{array}{c}\text { Specimen } \\
\text { Number }\end{array}$ & $\begin{array}{c}\text { Energy Absorbed, } \\
\mathbf{J}(\mathbf{f t}-\mathrm{lb})\end{array}$ \\
\hline 1 & $220(162)$ \\
2 & $259(191)$ \\
3 & $178(131)$ \\
4 & $301(222)$ \\
5 & $266(196)$ \\
6 & $256(189)$ \\
\hline Mean & $247(182)$ \\
\hline Standard & $42(31)$ \\
Deviation & \\
\hline
\end{tabular}




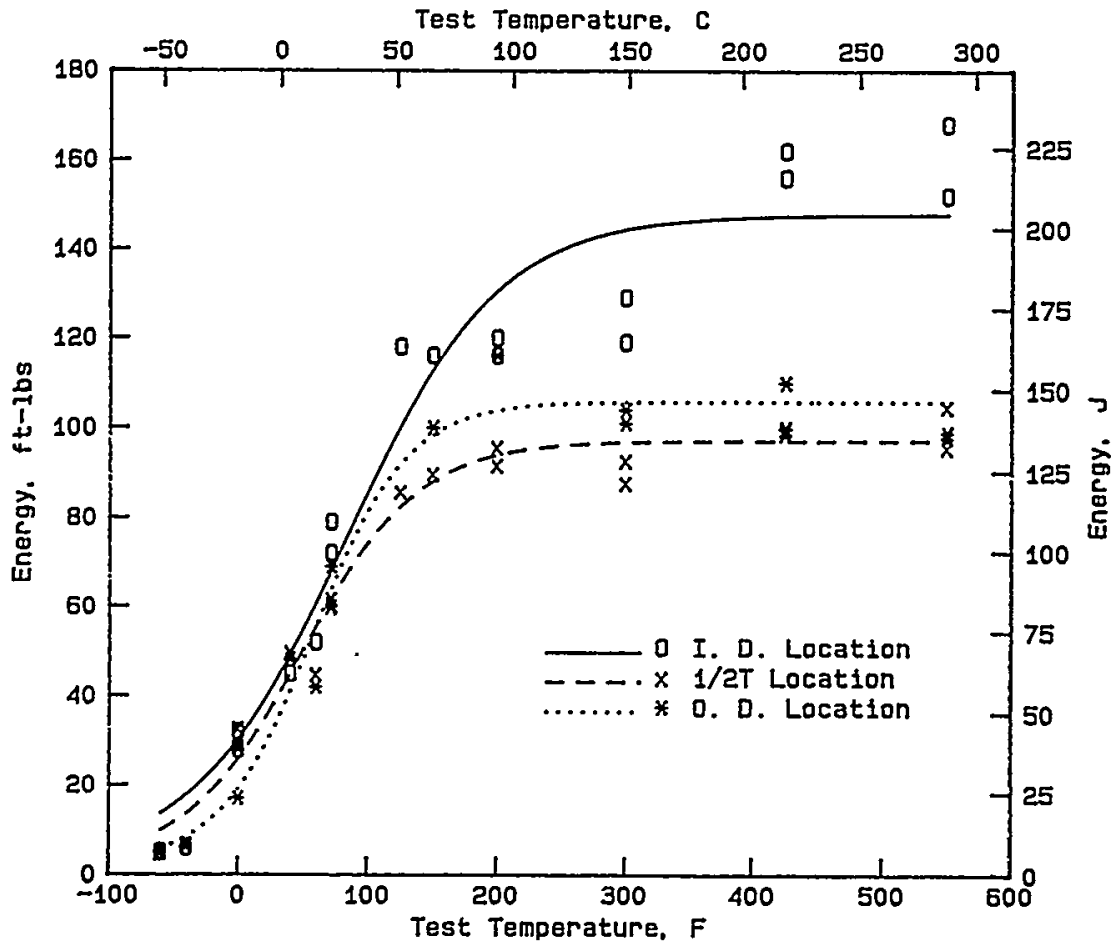

Figure 2.11 Absorbed energy in CVN tests for A516 Grade 70 Pipe DP2-F34 (L-C Orientation), from Reference 2.2

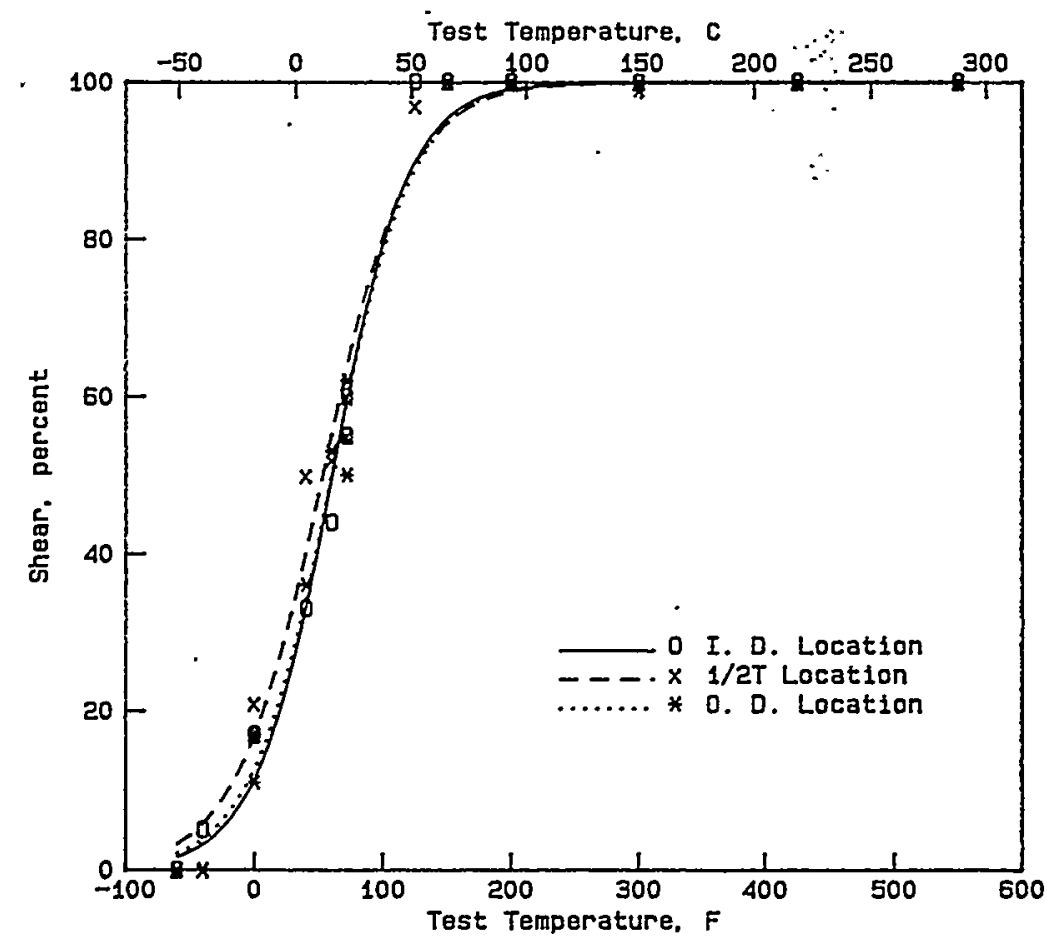

Figure 2.12 Fracture appearance (shear area percent) in CVN tests for A516 Grade 70 Pipe DP2-F34 (L-C Orientation), from Reference $\mathbf{2 . 2}$ 


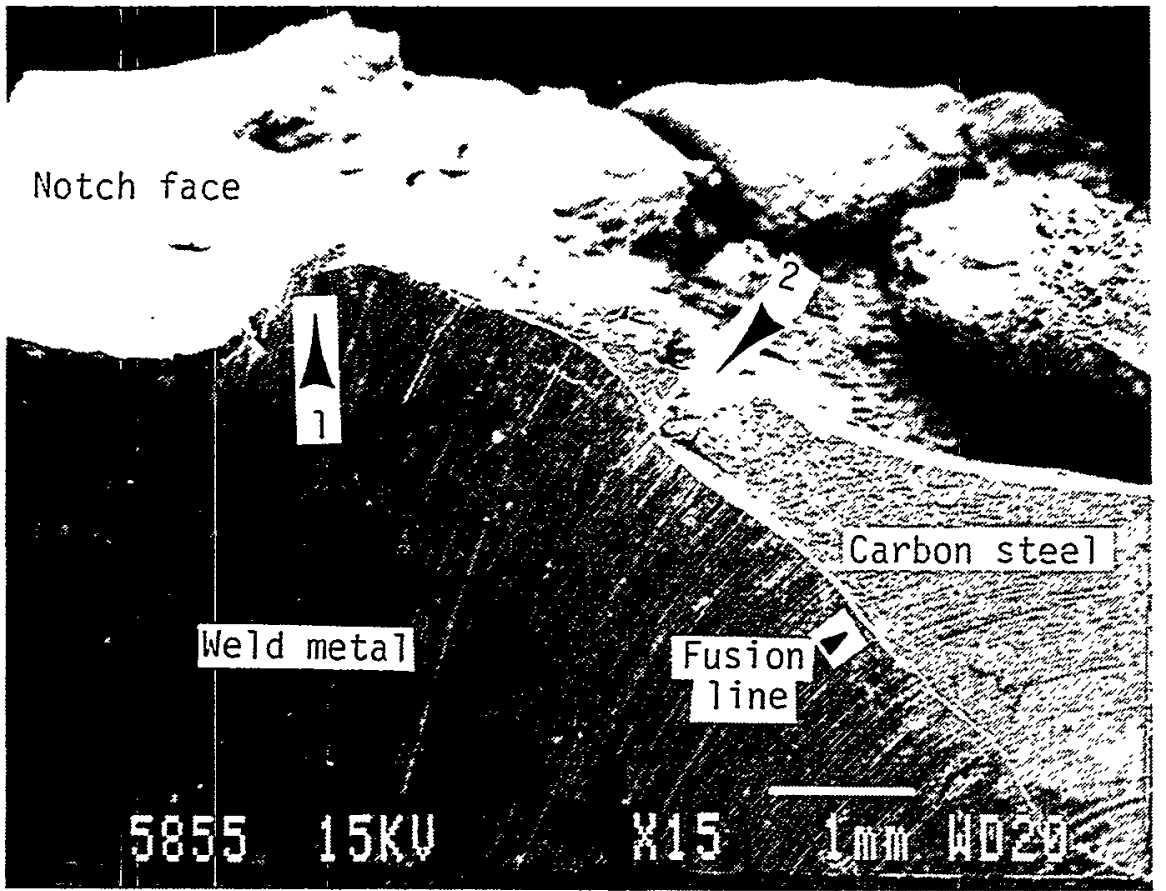

Figure 2.13 SEM photograph of Charpy Specimen Number 4 showing first part of the fracture path in the carbon steel immediately adjacent to the weld

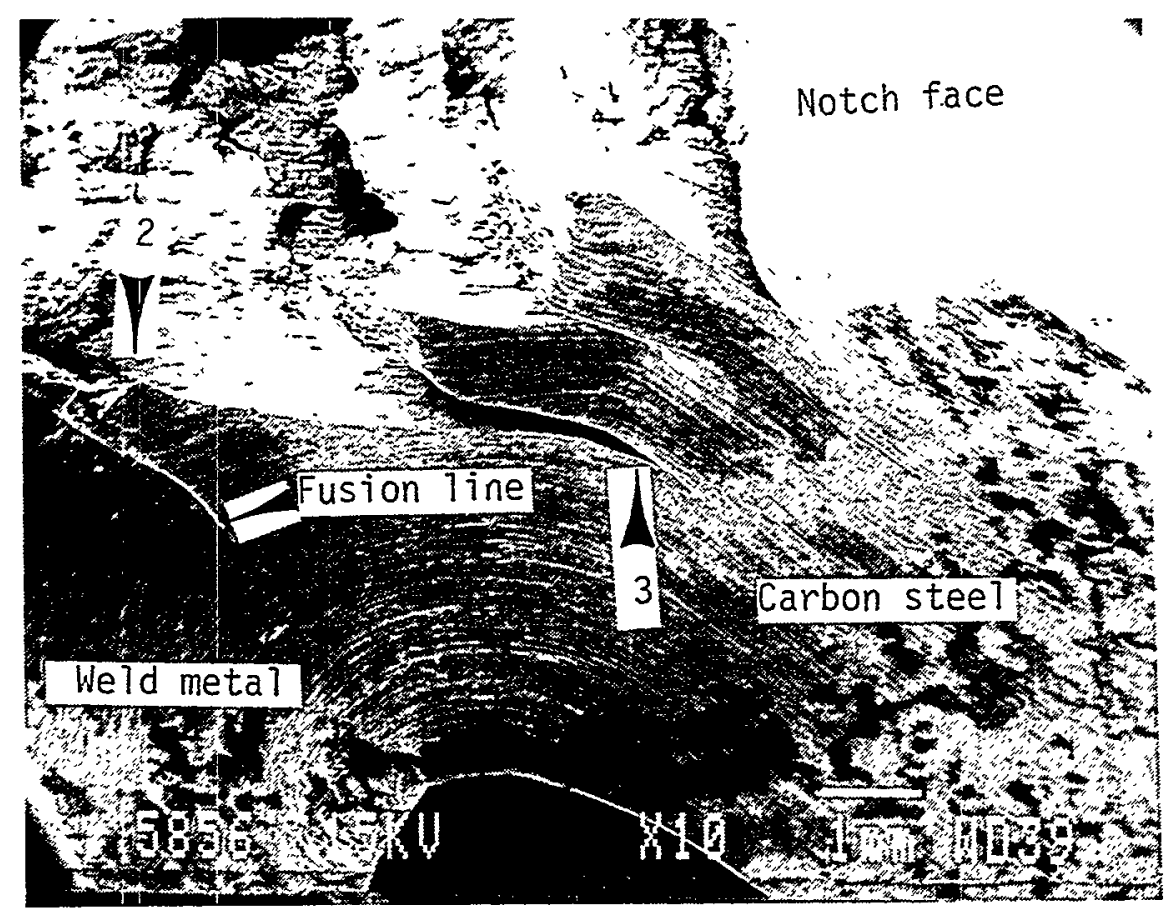

Figure 2.14 SEM photograph of L-C oriented Charpy Specimen Number 4 showing crack veering away from the fusion line and into the carbon steel 
Photomicrographs were taken of the mid-section of the Charpy specimen in order to determine whether there was a preferred alignment of weak regions in the carbon steel that caused the sharp deviation of the cracks. Figure 2.15 shows the crack tip of the split furthest from the notch. For this split, and for the others that were examined, there is no apparent microstructural feature that would cause the crack to follow the path that it did. Therefore, the cause of the longitudinal splitting was not determined. (Note: Such splits are common in L-R oriented specimens, but detailed examination showed the specimens were properly fabricated in the L-C orientation.)

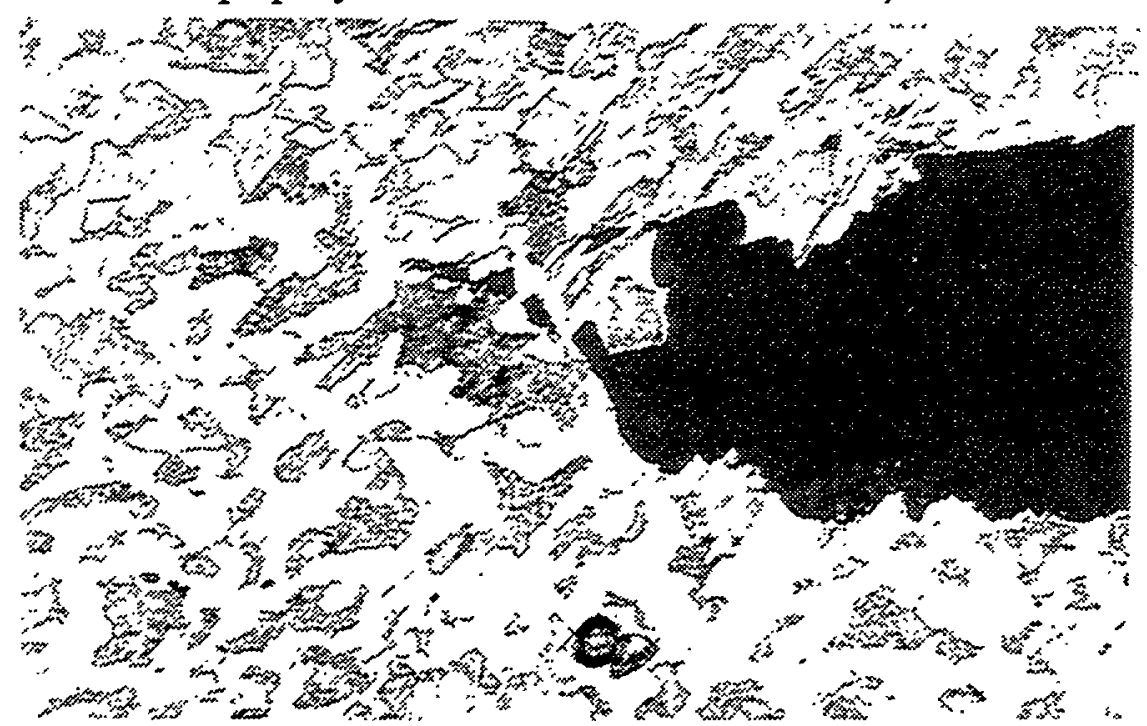

Figure 2.15 Photomicrograph of tip of crack in delamination of Charpy specimen of bimetallic weld DP2-F33

\subsection{J-Resistance Curve Test Data from C(T) Specimens}

In this section of the report, the results from the J-Resistance (J-R) curve testing for the carbon steel pipe, stainless steel safe end, and the carbon steel pipe/Inconel 182 fusion line region are presented. No data for the Inconel 182 weld were generated.

\subsubsection{J-R Curve Data for A516 Grade 70 Carbon Steel Pipe Material}

Two 4T planform-size compact type specimens (66-mm [2.6-inch] thick) were machined from the carbon steel pipe material. Both machining and testing were conducted at Materials Engineering Associates as part of an earlier program (Ref. 2.2). Specimens were oriented such that crack growth would be in the circumferential direction ( $\mathrm{L}-\mathrm{C}$ orientation). Specimen thicknesses were the maximum. achievable from the 86-mm (3.4-inch) nominal wall thickness of the pipe. One of the $4 \mathrm{~T}$ specimens was sidegrooved 10 percent per side and one was not sidegrooved.

In addition to the $4 \mathrm{~T}$ planform-size compact specimens machined and tested at MEA, two $1 \mathrm{~T}$ compact specimens were fabricated and tested at Battelle. These also had an L-C orientation. Both of these $1 T$ specimens were sidegrooved 10-percent per side. 
Each specimen had a fatigue precrack at the tip of the machined notch. The fatigue cracking was conducted under the guidelines of ASTM E813-81, and the crack was grown at least 2.5 percent of the specimen width. The final crack length was such that a/W was about 0.5 .

Tests of the $4 \mathrm{~T}$ planform-size compact specimens tested at MEA were conducted at $288 \mathrm{C}$ (550 F) and employed the unloading compliance method to determine crack extension. From the measured loads and load-line displacements, values of $\mathrm{J}$ were calculated for each crack length.

The $1 \mathrm{~T}$ specimens tested at Battelle were tested at $288 \mathrm{C}(550 \mathrm{~F})$ in an earlier program (Ref. 2.1). The displacement rate was designed to cause crack initiation in about 5 to 20 minutes. Data obtained were load $(P)$, load-line displacement (LLD), and d-c electric potential (U). Tests were terminated when the crack had extended by an amount equal to 55 to 60 percent of the original ligament. The specimens were sidegrooved 10 percent per side. Crack growth was accompanied by thickness reduction at the crack plane (necking), of the order of 5 percent.

The point of crack initiation in the $1 \mathrm{~T}$ specimens was estimated from the direct-current electric potential data. To accomplish this, a graph of electric potential versus load-line displacement was examined for points of slope change prior to maximum load. Engineering judgment then was applied to estimate $U_{0}$, the value of $U$ at crack initiation. Crack growth beyond initiation was calculated from the ratio $U / U_{0}$ using the Johnson equation (Ref 2.3). The term for the spacing of the voltage probes (2y) in the Johnson expression was allowed to increase in proportion to the LLD as the test progressed because experience has shown that this procedure provides a more accurate estimate of crack growth in ductile materials (Ref. 2.4). The final calculated crack extension and the final physical crack extension agreed within 1 to 2 percent; in each case, the calculated values were greater than the actual values.

Deformation $J\left(J_{D}\right)$ and Modified $J\left(J_{M}\right)$ were calculated for each specimen. $J_{D}$ was calculated in the manner specified in ASTM E813-81 following a method developed by Ernst and Paris that takes into account crack growth (Ref. 2.5). $\mathrm{J}_{\mathrm{M}}$ was calculated in the manner developed by Ernst, Paris, and Landes (Ref. 2.6). In calculating both $\mathrm{J}_{\mathrm{D}}$ and $\mathrm{J}_{\mathrm{M}}$, no account was taken of the thinning of the specimen ahead of the crack or of the thickening at the back edge.

A graph of $J_{D}$ versus crack extension is shown in Figure 2.16 for the $4 \mathrm{~T}$ specimens and in Figure 2.17 for the $1 \mathrm{~T}$ planform-size compact specimens. $\mathrm{J}$ values at crack initiation in the MEA tests were obtained by constructing a blunting line on the J- $\Delta \mathrm{a}$ graphs, namely

$$
\mathrm{J}=2 \sigma_{\mathrm{f}} \Delta \mathrm{a}
$$

where $\sigma_{\mathrm{f}}$ is the flow stress (the average of the yield and ultimate strengths). A straight line was fitted to the data points between the two exclusion lines, parallel to the blunting line, and was extrapolated to the blunting line to provide an estimate of $\mathrm{J}$ at crack initiation. 


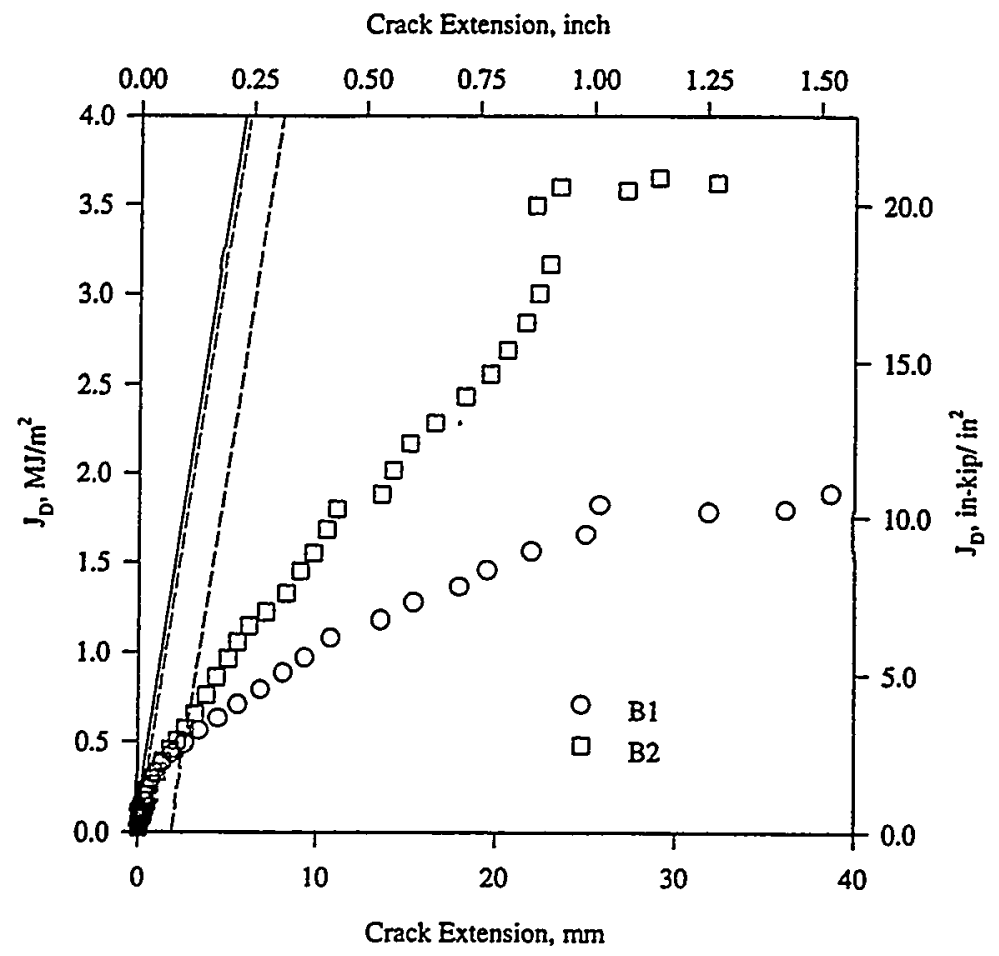

Figure 2.16 J-resistance curves for A516 Grade 70 base metal (Pipe F34) 4T planform-size compact specimens tested at $288 \mathrm{C}(550 \mathrm{~F})$ from Reference 2.2

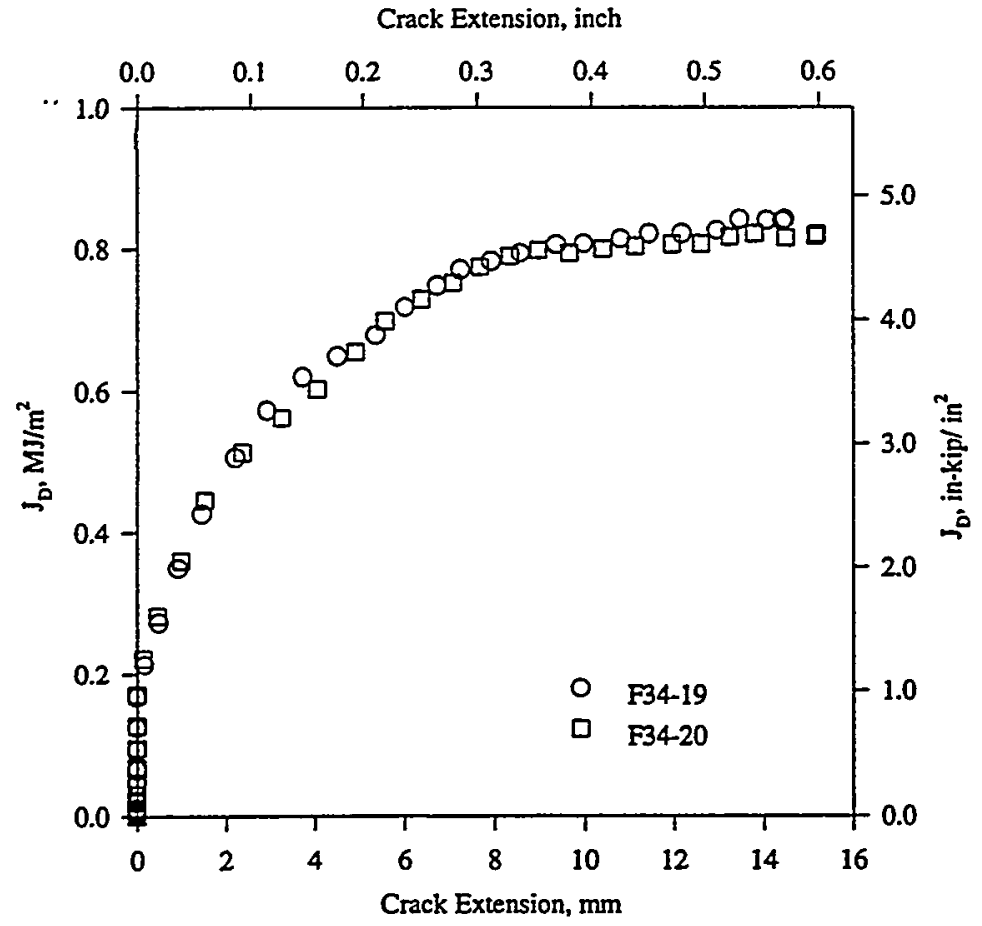

Figure 2.17 J-resistance curves for A516 Grade 70 base metal (Pipe F34) 1T compact specimens tested at $288 \mathrm{C}(550 \mathrm{~F})$ from Reference 2.1 
Values of $J$ at initiation and values of $d J / d a$ for the initial portion of the $J-R$ curve for both the MEA 4T tests and the Battelle 1T tests are shown in Table 2.9. The values of $\mathrm{dJ} / \mathrm{da}$ obtained from Battelle tests were for $\Delta \mathrm{a}$ values in the range of approximately 0.15 to $1.5 \mathrm{~mm}(0.006$ to 0.060 inches $)$. In the MEA tests, they were obtained for $\triangle$ a values within the exclusion lines. As can be seen in Table 2.9 , the agreement in the $\mathrm{J}_{\mathrm{i}}$ and $\mathrm{dJ} / \mathrm{da}$ values for the three 20 -percent side-grooved specimens, both $1 \mathrm{~T}$ and $4 \mathrm{~T}$ size, was excellent. However, the $\mathrm{J}_{\mathrm{i}}$ value for the nonside-grooved $4 \mathrm{~T}$ specimen tested at MEA was less than half the $\mathrm{J}_{\mathrm{i}}$ value for the three side-grooved specimens.

Table 2.9 Summary of $\mathrm{J}_{\mathrm{i}}$ and dJ/da values for A516 Grade 70 base metal Pipe DP2-F34 compact specimens (Tested at $288 \mathrm{C}$ ( $550 \mathrm{~F})$; L-C orientation)

\begin{tabular}{|c|c|c|c|c|c|}
\hline $\begin{array}{l}\text { Spec. Ident. } \\
\text { No. }\end{array}$ & $\begin{array}{l}\text { Specimen } \\
\text { Size }\end{array}$ & $\begin{array}{l}\text { Notch } \\
\text { Type }^{(a)}\end{array}$ & $\begin{array}{c}\text { Percent } \\
\text { Side-grooves }\end{array}$ & $\begin{array}{l}J \text { at Initiation, } \\
\mathrm{kJ} / \mathrm{m}^{2}\left(\mathrm{in}-\mathrm{lb} / \mathbf{i n}^{2}\right)\end{array}$ & $\begin{array}{c}\mathrm{dJ} / \mathrm{da},{ }^{(b)} \\
\mathrm{MJ} / \mathrm{m}^{3}\left(\mathrm{in}-\mathrm{lb} / \mathrm{in}^{3}\right)\end{array}$ \\
\hline F34-19 & $1 \mathrm{~T}$ & $\mathrm{FC}$ & 20 & $179^{(\mathrm{c})}\left(1,020^{(\mathrm{c})}\right)$ & $181(26,300)$ \\
\hline F34-20 & $1 \mathrm{~T}$ & $\mathrm{FC}$ & 20 & $191^{(\mathrm{c})}\left(1,090^{(\mathrm{c})}\right)$ & $176(25,500)$ \\
\hline $\mathrm{B} 1^{(\mathrm{d})}$ & $4 \mathrm{~T}$ & $\mathrm{FC}$ & 20 & $192^{(\mathrm{c})}\left(1,095^{(\mathrm{c})}\right)$ & $152(22,000)$ \\
\hline $\mathrm{B} 2^{(\mathrm{d})}$ & $4 \mathrm{~T}$ & FC & 0 & $84^{(\mathrm{c})}\left(480^{(\mathrm{c})}\right)$ & $218(31,600)$ \\
\hline
\end{tabular}

(a) $\mathrm{FC}=$ Fatigue crack.

(b) Calculated between $0.15 \mathrm{~mm}$ (0.006 inch) and $1.5 \mathrm{~mm}$ ( 0.060 inch).

(c) Meets $\mathrm{J}_{\text {Ic }}$ validity requirements of ASTM E813-89.

(d) Fabricated and tested at Materials Engineering Associates.

\subsubsection{J-R Curve Data for SA182 F316 Forged Stainless Steel Safe-End Material}

Two 1T planform-size compact specimens were machined in the L-C orientation from near the midwall region of the F316 forged stainless steel safe end for the purpose of conducting J-resistance tests. The specimens were not side grooved. The specimens were fatigue precracked according to the specifications in ASTM E1152-87, "Standard Test Method for Determining J-R Curves", to produce an initial average crack length of approximately $0.54 \mathrm{~W}$.

Specimens were tested at $288 \mathrm{C}(550 \mathrm{~F})$ in displacement control in a screw-driven Instron machine having a capacity of $275 \mathrm{kN}(50,000 \mathrm{lbs})$. The crosshead speed was $0.021 \mathrm{~mm} / \mathrm{sec}$ ( 0.05 inches $/ \mathrm{min})$, which was chosen to cause crack initiation in four to seven minutes.

Each of the specimens exhibited extensive crack tip blunting and thickness reduction (necking) prior to and during ductile crack extension. Thickness reductions were approximately 30 to 35 percent of the original specimen thickness. No attempt was made to account for these thickness reductions when calculating $\mathrm{J}$ values. 
The point of crack initiation and crack growth data were estimated from the electric potential data using the same procedures as described previously for the A516 Grade 70 carbon steel pipe 1T C(T) specimens tested at Battelle.

The procedures used to calculate $J$ were those specified in ASTM E1152-87. In addition, values of Modified J were calculated, following the procedures outlined by Ernst (Ref. 2.6).

J-resistance curves for the two 1T compact specimens are shown in Figure 2.18. Table 2.10 is a summary table showing the $\mathrm{J}_{\mathrm{i}}$ and $\mathrm{dJ} / \mathrm{da}$ values for these two specimens. The values of $\mathrm{dJ} / \mathrm{da}$ are for crack-extension values in the range of approximately 0.15 to $1.5 \mathrm{~mm}(0.006$ to 0.060 inch).

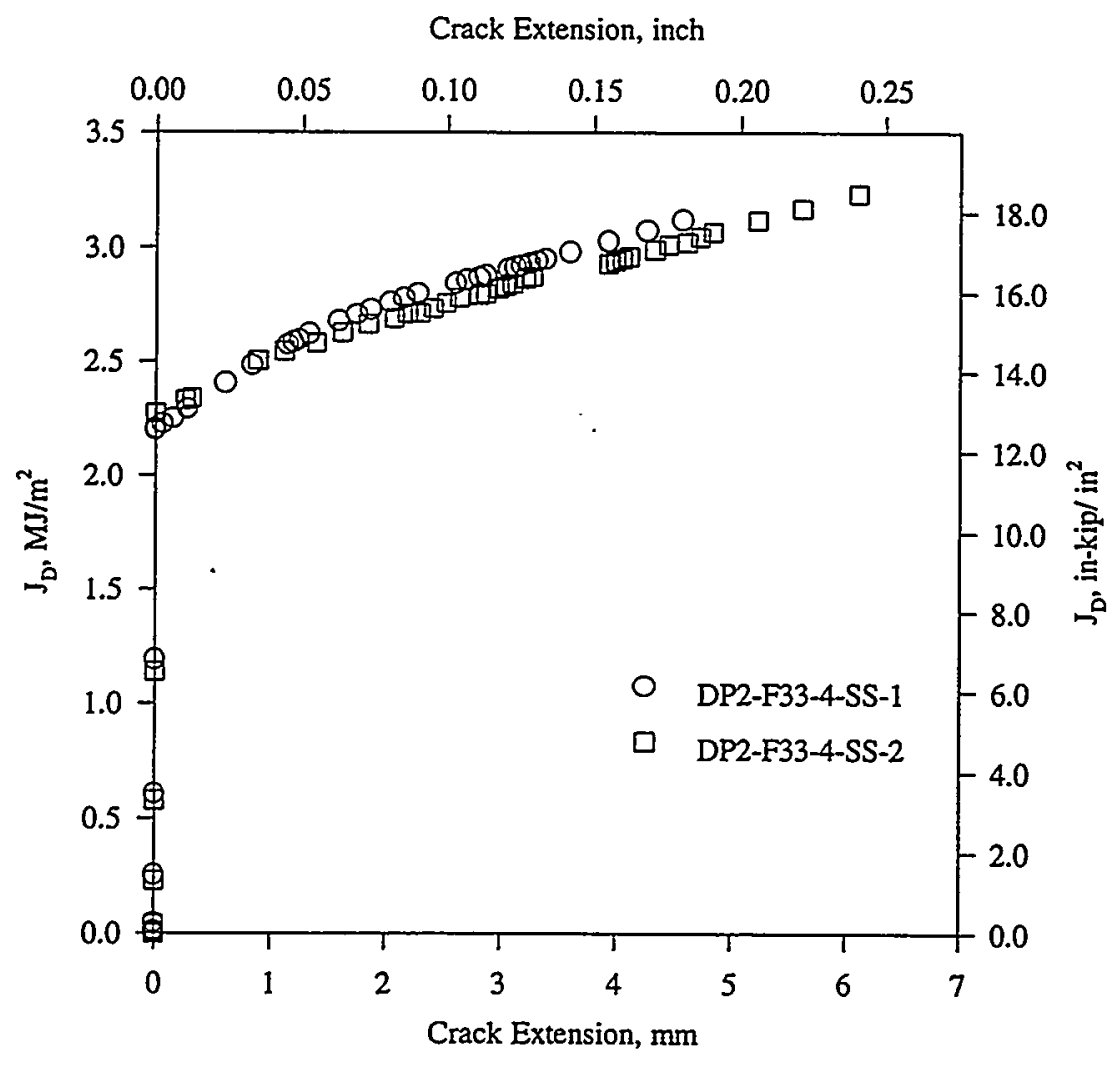

Figure 2.18 J-resistance curves for SA182 F316 forged stainless steel safe end tested at $288 \mathrm{C}(550 \mathrm{~F})$ 
Table 2.10 Summary of $J_{i}$ and $d J / d a$ values for SA182 F316 forged stainless steel safe-end material tested at $288 \mathrm{C}(550 \mathrm{~F})$ on $1 \mathrm{~T} \mathrm{L-C} \mathrm{oriented} \mathrm{compact} \mathrm{specimens}$

\begin{tabular}{ccccc}
\hline $\begin{array}{c}\text { Specimen Ident. } \\
\text { No. }\end{array}$ & $\begin{array}{c}\text { Notch } \\
\text { Type }^{(\mathbf{a})}\end{array}$ & $\begin{array}{c}\text { Percent } \\
\text { Side-grooves }\end{array}$ & $\begin{array}{c}\mathbf{J} \text { at Initiation, } \\
\mathbf{k J} / \mathbf{m}^{\mathbf{2}}\left(\mathbf{i n - l b} / \mathbf{i n}^{2}\right)\end{array}$ & $\begin{array}{c}\mathbf{d J} / \mathbf{d a} \text {, }^{(\mathbf{b})} \\
\mathbf{M J} / \mathbf{m}^{\mathbf{3}} \text { (in-lb/in }\end{array}$ \\
\hline F33-4-SS-1 & FC & 0 & $2,166(12,400)$ & $174(25,300)$ \\
F33-4-SS-2 & FC & 0 & $2,299(13,100)$ & $199(28,900)$ \\
Average & - & - & $2,233(12,750)$ & $187(27,100)$ \\
\hline
\end{tabular}

(a) $\mathrm{FC}=$ fatigue crack.

(b) Calculated between $0.15 \mathrm{~mm}(0.006 \mathrm{inch})$ and $1.5 \mathrm{~mm}(0.060 \mathrm{inch})$.

\subsubsection{J-R Curve Data for the A516 Grade 70 Pipe/Inconel 182 Fusion-Line Region}

As part of this program, four $2 \mathrm{~T}$ compact specimens were machined from the fusion-line region for the purpose of conducting J-resistance tests. Two of the specimens were fatigue precracked and two were machined with a sharp machined notch (root radius of $0.2 \mathrm{~mm}$ [0.008 inch]), the latter to simulate the notch used in the corresponding pipe tests. The $C(T)$ specimens were machined with the notch in the L-C orientation in order to simulate the circumferential through-wall crack of the pipe test. The specimen blanks were frequently etched during fabrication in order to ensure that the notch locations were properly positioned immediately adjacent to the A516 Grade 70/Inconel 182 fusion line in the heat-affected zone of the carbon steel base metal.

Figure 2.19 shows photographs of the sides of the etched $C(T)$ specimens prior to the tests showing the locations of the wire-cut electric-discharge-machine (EDM) notches with respect to the weld fusion line. Figures 2.19a and 2.19b are photographs of Specimens DP2-F33W-1 and DP2-F33W-2, respectively, showing that the notches for these two specimens were slightly offset from the fusion line on the A516 Grade 70 steel side of the welds. Figures $2.19 \mathrm{c}$ and $2.19 \mathrm{~d}$ are photographs of Specimens DP2-F33W-3 and DP2-F33W-4, respectively, showing that the notches for these two specimens were centered almost directly along the fusion line.

The $\mathrm{C}(\mathrm{T})$ specimens were tested at $288 \mathrm{C}(550 \mathrm{~F})$ in displacement control in a servohydraulic machine having a capacity of $580 \mathrm{kN}(130,000 \mathrm{lb})$. The crosshead speed was $1.27 \mathrm{~mm} / \mathrm{min}$ $(0.05 \mathrm{in} / \mathrm{min})$ and was intended to cause crack initiation in four to seven minutes. Quantities recorded during each test included load, load-line displacement, and direct-current electric potential. The electric potential was used to indicate the point of crack initiation and the amount of crack extension. Each test was terminated when the crack had extended by an amount equal to 40 to 55 percent of the original ligament. The total elapsed time for each test was approximately six to thirteen minutes. 

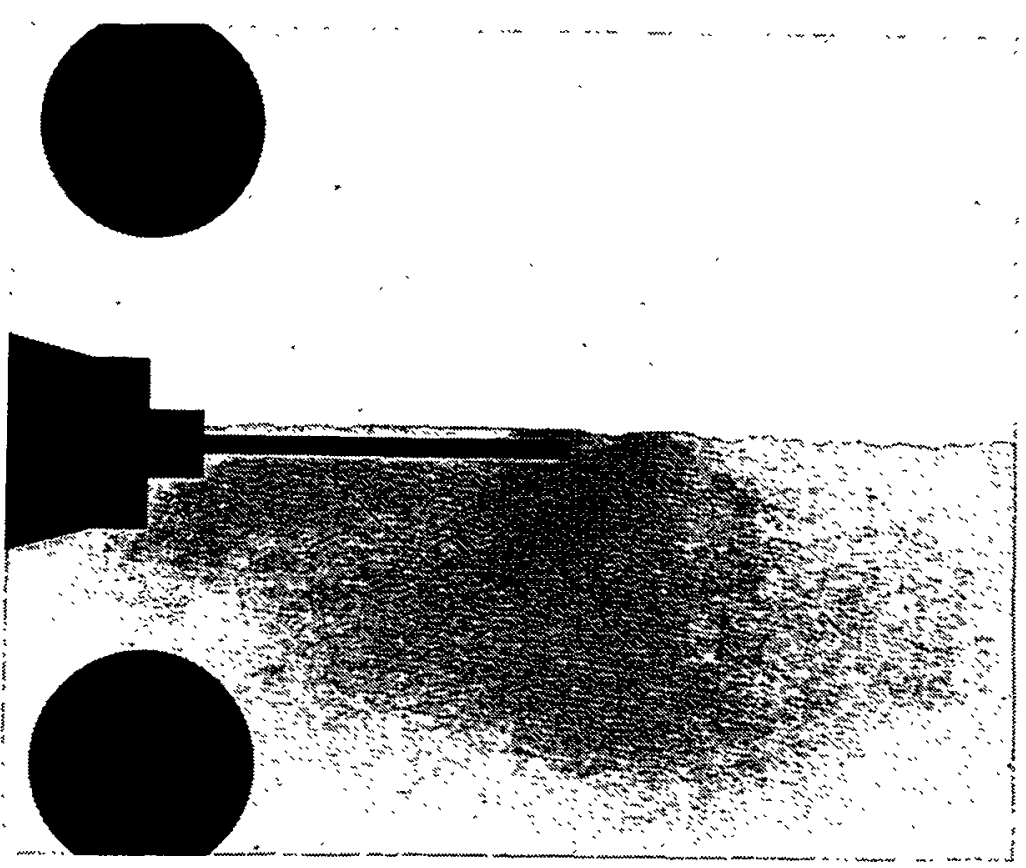

(a) DP2-F33W-1

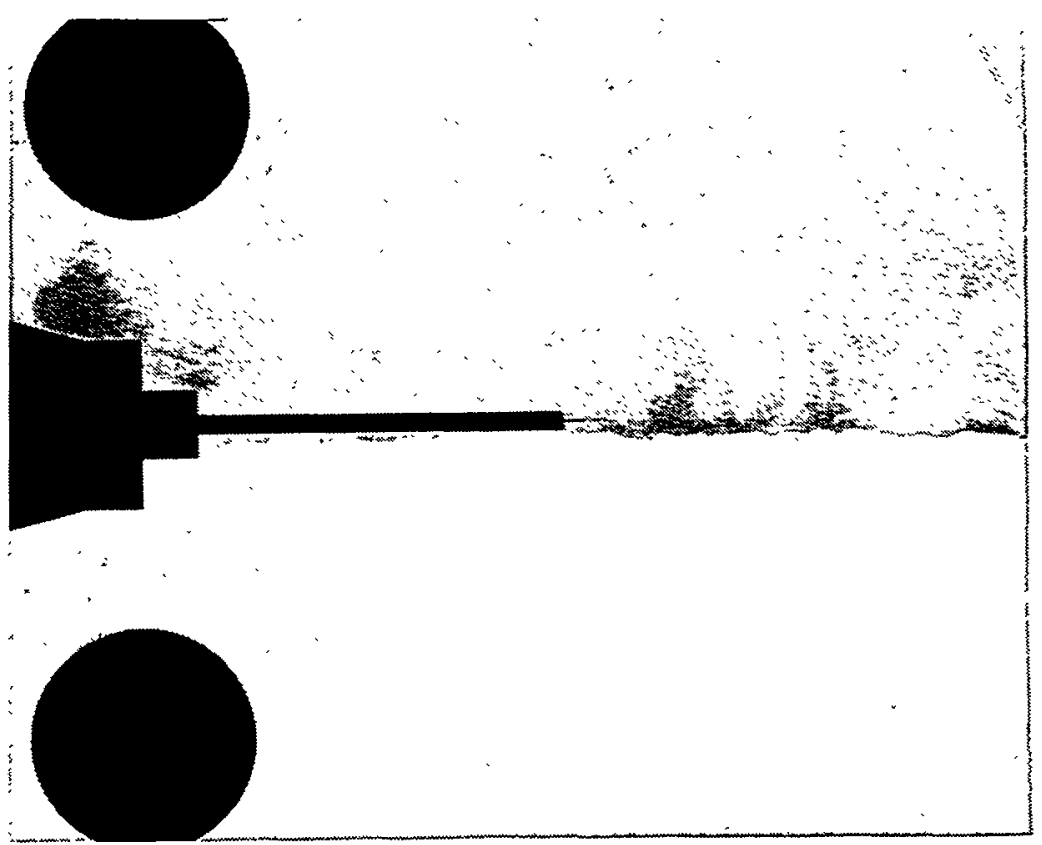

(b) DP2-F33W-2

Figure 2.19 Photographs of the sides of the etched $C(T)$ specimens prior to test showing the locations of the electric-discharge-machine (EDM) notches with respect to the weld fusion line 


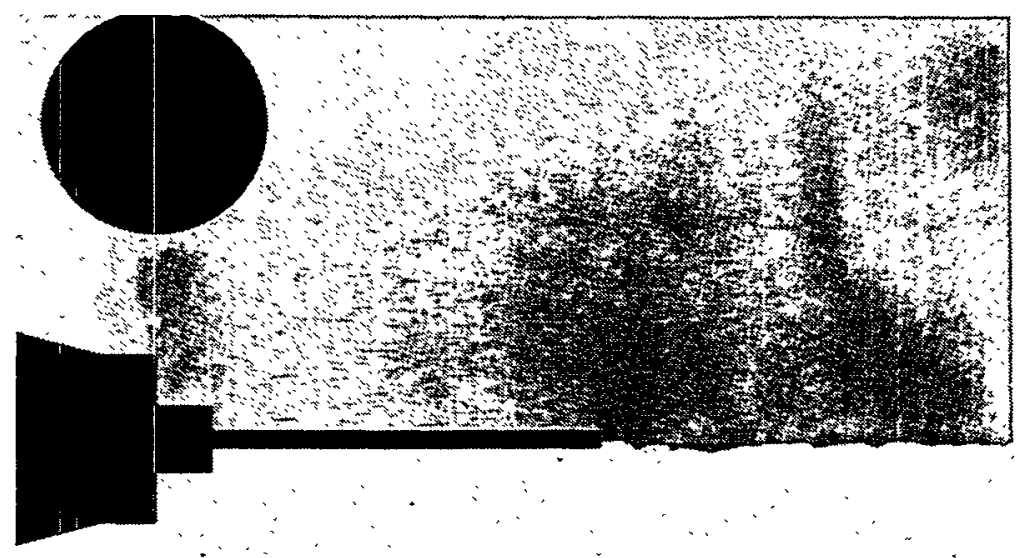

(c) DP2-F33W-3
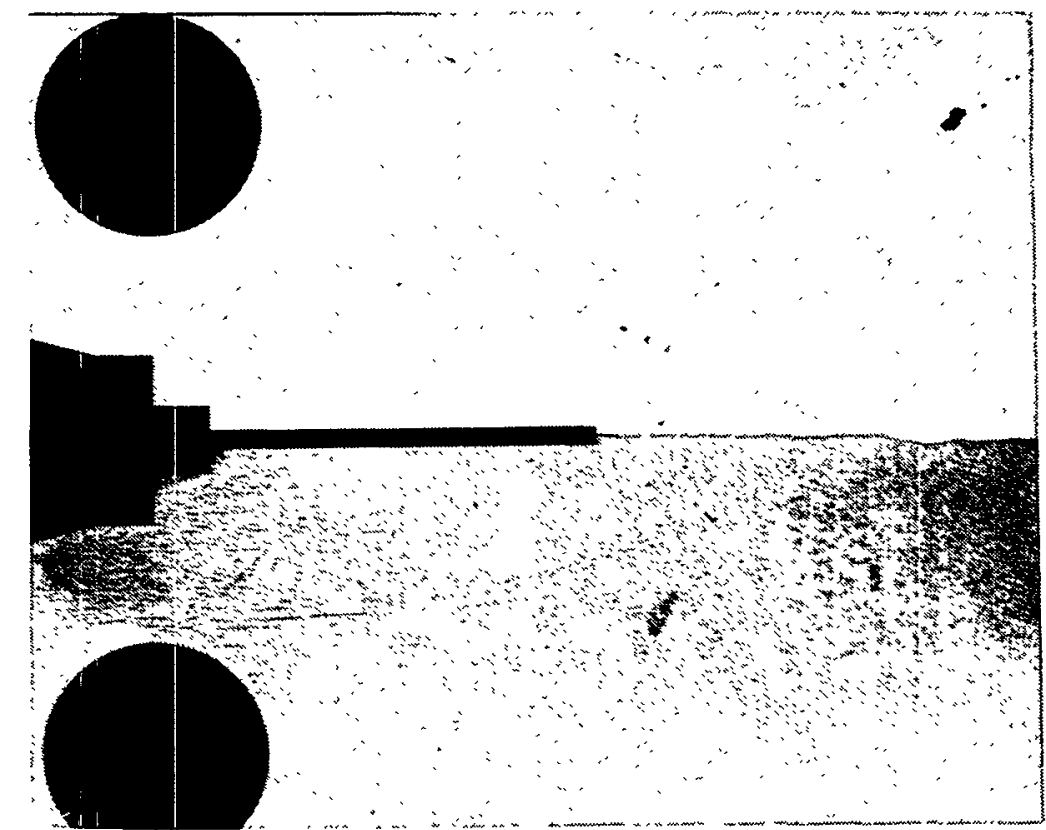

(d) DP2-F33W-4

Figure 2.19 Continued 
The point of crack initiation and crack growth data were initially estimated from the electric-potential data using the same procedures described previously for the A516 Grade 70 steel 1T C(T) specimens tested at Battelle. The final crack extension calculated from electric potential did not provide a reasonable estimate of the final physical crack extension. This discrepancy is believed to be inherent in bimetallic welds and to arise from the Peltier effect (voltage generated at a dissimilar-metal junction). In order to evaluate the error introduced, a correction was made by subtracting the estimated Peltier effect (745 microvolts) from all of the electric potential readings for one specimen. This procedure produced satisfactory agreement between the electric potential crack growth data and physical crack growth measurements. The Peltier-corrected data were then analyzed to produce a J-R curve that was essentially identical to the J-R curve produced by our usual correction method (which was applied without a Peltier correction). The usual method involves multiplying each electricpotential crack growth point by the end-of-test ratio of the physical crack growth to the electric potential crack growth. It should be pointed out that there is some ambiguity in the measurement of physical crack growth because of the extremely irregular fracture surfaces of these specimens, one of which is shown in Figure 2.20.

The cracks grew away from the fusion line and into the A516 Grade 70 carbon steel, an observation that is qualitatively consistent with the behavior of the Charpy specimens discussed in the previous section. However, the deviation of the crack from its intended plane of travel was relatively small in the $C(T)$ specimens, very unlike the right-angle path deviations in the Charpy specimens. Figure 2.20 shows two views of the broken compact specimen F33W-4. Figure 2.20a shows the side view of the specimen in which one can see that the crack tried to follow the fusion line along one edge of the specimen, but turned and grew in the carbon steel for most of the crack front. (Figure 2.20b is a close up [twice the magnification] of this side view of this compact specimen.) Figure 2.20c shows a plan view of the fracture surface for this same specimen. (Figure $2.20 \mathrm{~d}$ is a close up [twice the magnification] of this plan view of the fracture surface.) Of note in this figure are the small "thumb nail" regions of Inconel 182 buttered weld metal along the tip of the machined notch down the length of the crack front. This demonstrates the success with which we were able to locate the notch along the fusion line, at least for this specimen.

Values for $\mathrm{J}_{\mathrm{i}}$ and $\mathrm{dJ} / \mathrm{da}$ for the bimetallic weld region are summarized in Table 2.11. The values for $\mathrm{dJ} / \mathrm{da}$ are for crack extensions in the range of 0.20 to $2.0 \mathrm{~mm}$ (0.008 to 0.079 inch). Figures 2.21 and 2.22 show the J-R curves for fatigue-precracked and notched fusion-line specimens, respectively, while Figure 2.23 is a composite of all the J-R curves for the fusion line. The major results are that the notched specimens have higher initiation $J$ values and higher initial slopes of the J-R curves than do the precracked specimens. However, the effect of crack-starter geometry diminishes with increasing crack growth and is unimportant after 10 to 15 millimeters of crack growth. 


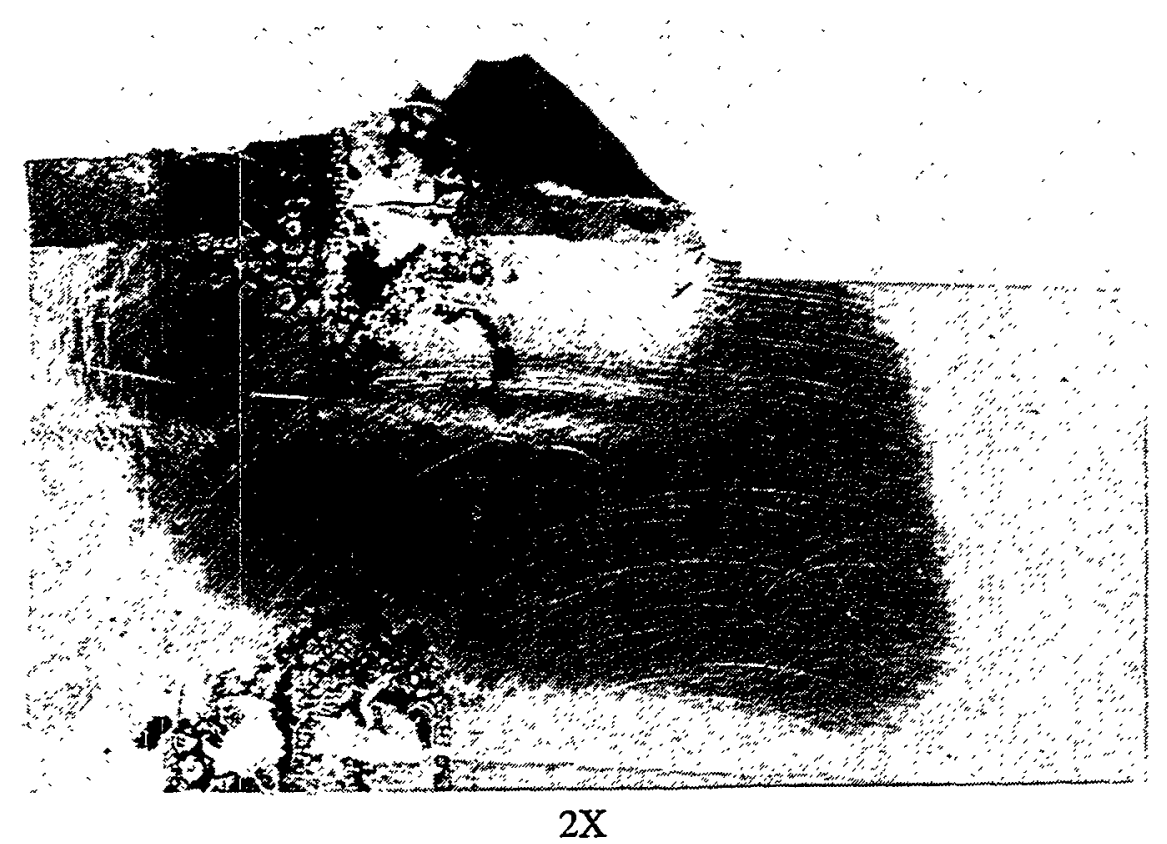

(a) Side View

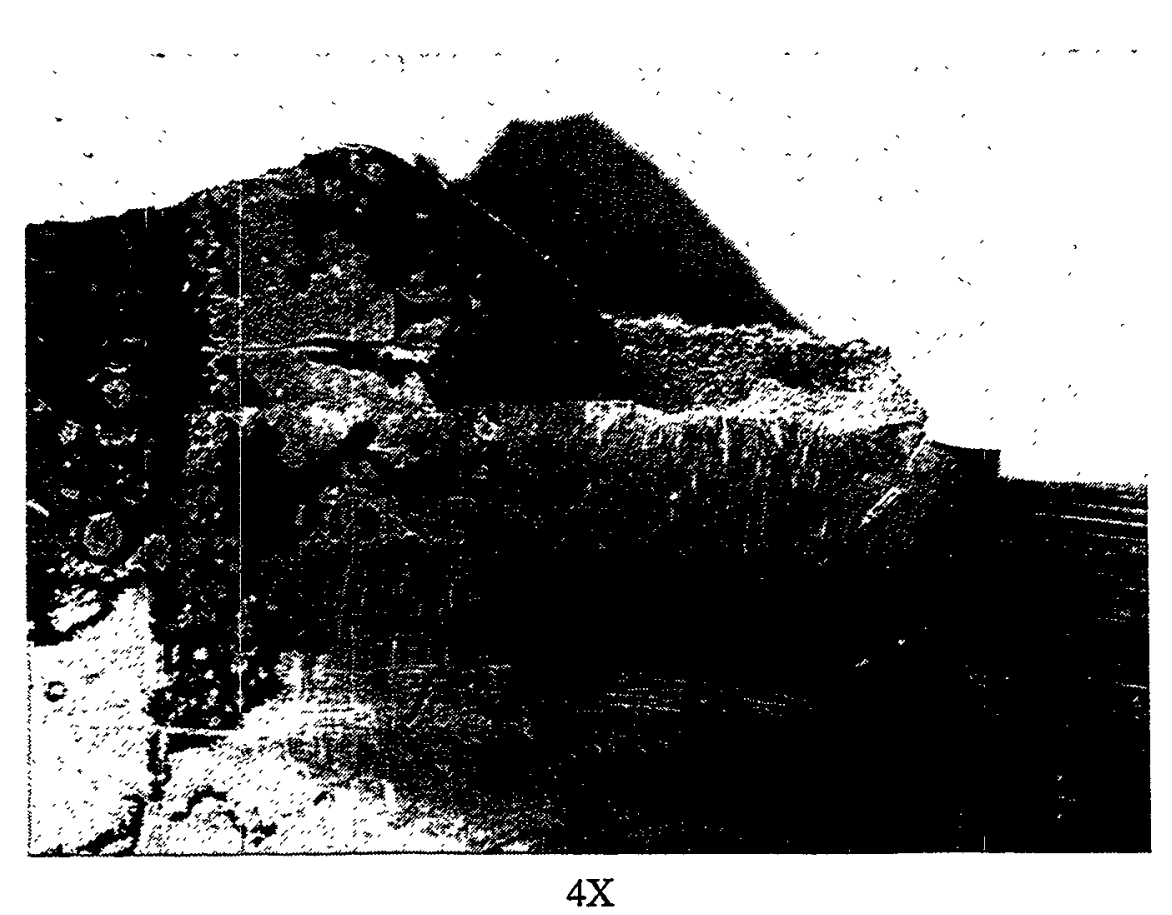

(b) Side View

Figure 2.20 Fracture surface of broken bimetallic weld compact specimen DP2-F33W-4 


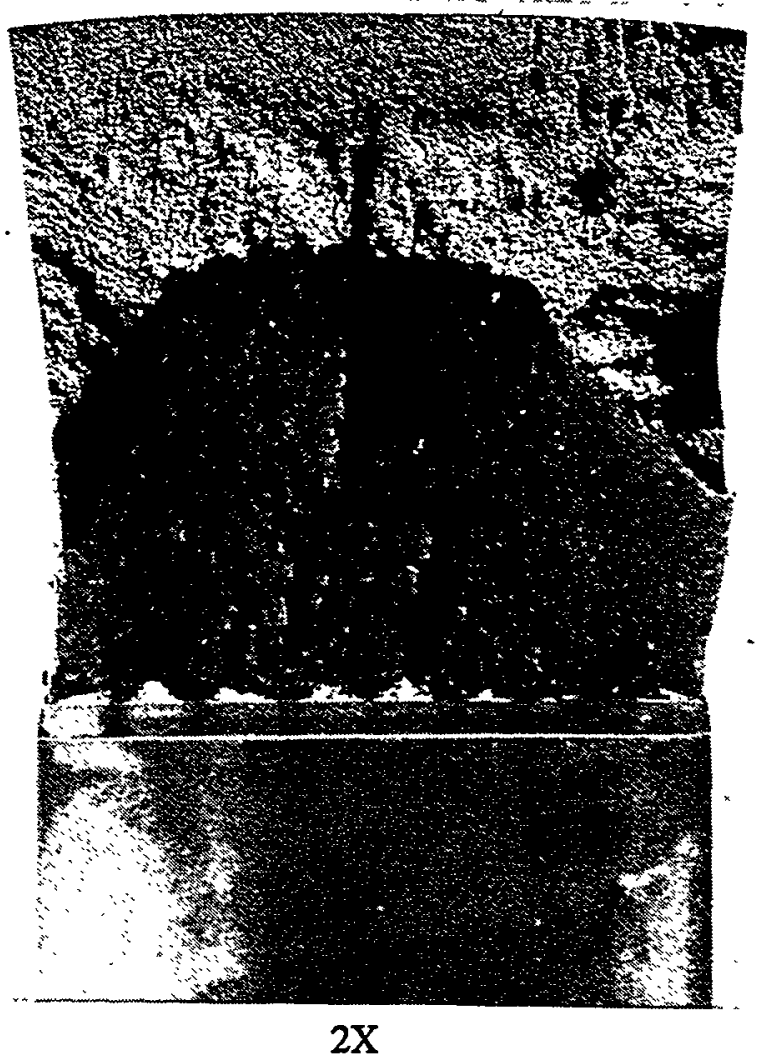

(c) Plan View

(Note crack tip along weld beads from buttering.)

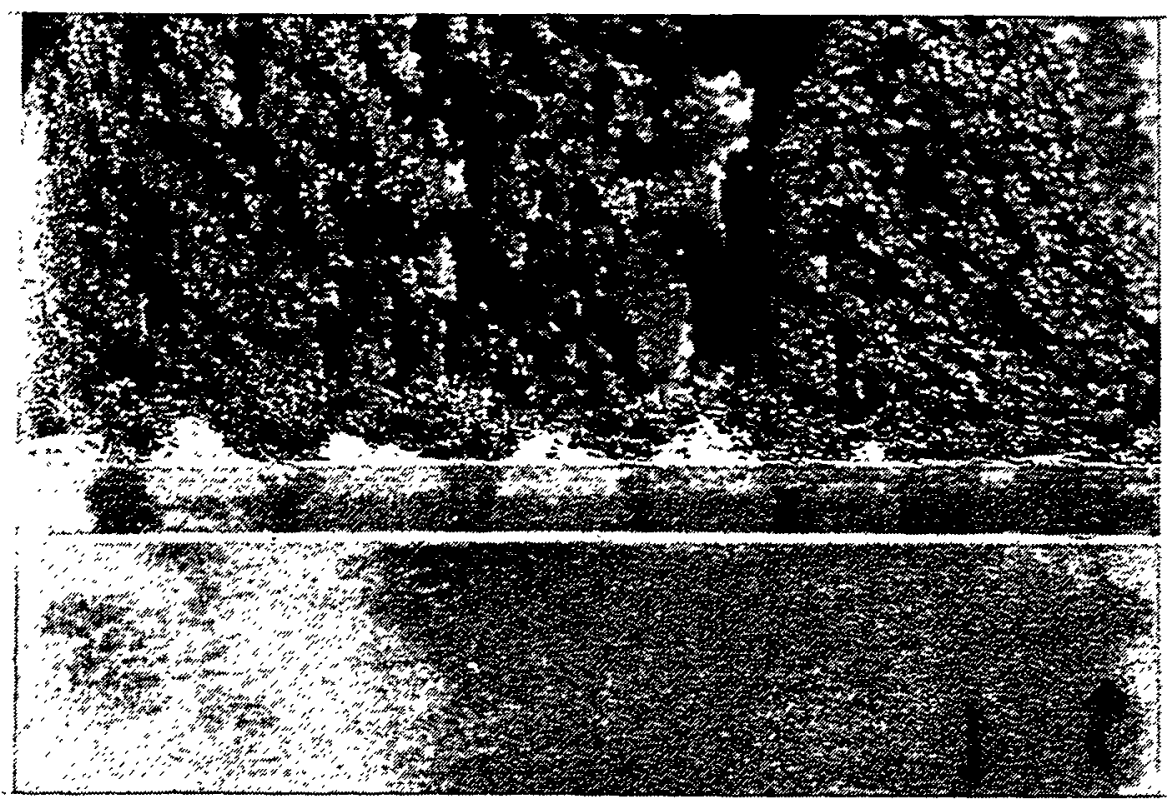

$4 \mathrm{X}$

(d) Plan View

Figure 2.20 Continued 
Table 2.11 Summary of $J_{i}$ and $d J / d a$ values at $288 \mathrm{C}(550 \mathrm{~F})$ for bimetallic weld region obtained from compact specimens

\begin{tabular}{|c|c|c|}
\hline Specimen Identification & $\begin{array}{l}\mathrm{J} \text { at Initiation, } \\
\mathrm{kJ} / \mathrm{m}^{2}\left(\mathrm{in}-\mathrm{lb} / \mathrm{in}^{2}\right)\end{array}$ & $\begin{array}{c}\mathrm{dJ} / \mathrm{da},{ }^{(\mathrm{a})} \\
\mathrm{MJ} / \mathrm{m}^{3}\left(\mathbf{i n}-\mathrm{lb} / \mathbf{i n}^{3}\right) \\
\end{array}$ \\
\hline$F 33 W-1^{(b)}$ & $308(1,760)$ & $130(18,900)$ \\
\hline$F 33 W-2^{(b)}$ & $385(2,200)$ & $102(14,800)$ \\
\hline Average & $347(1,983)$ & $116(16,800)$ \\
\hline $\mathrm{F} 33 \mathrm{~W}-3^{(\mathrm{c})}$ & $574(3,280)$ & $225(32,700)$ \\
\hline $\mathrm{F} 33 \mathrm{~W}-4^{(\mathrm{c})}$ & $793(4,530)$ & $223(32,400)$ \\
\hline Average & $684(3,910)$ & $224(32,500)$ \\
\hline
\end{tabular}

(a) During initial crack growth between $0.15 \mathrm{~mm}(0.006$ inch) and $1.50 \mathrm{~mm}(0.060$ inch)

(b) Fatigue precracked

(c) Sharp machine notched

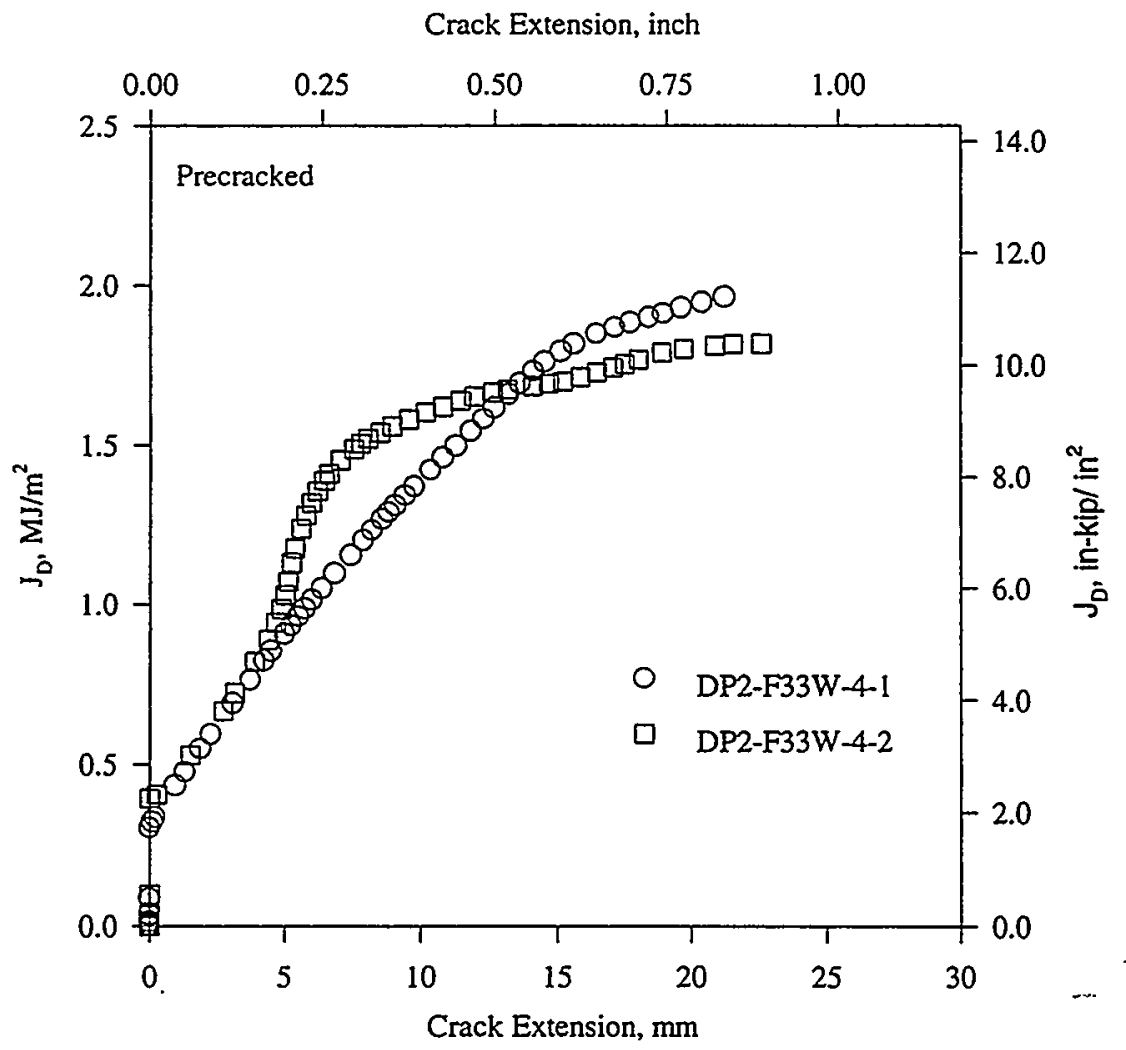

Figure 2.21 J-resistance curve for fatigue-precracked fusion line $\mathbf{C}(\mathrm{T})$ specimens tested at $288 \mathrm{C}(550 \mathrm{~F})$ 


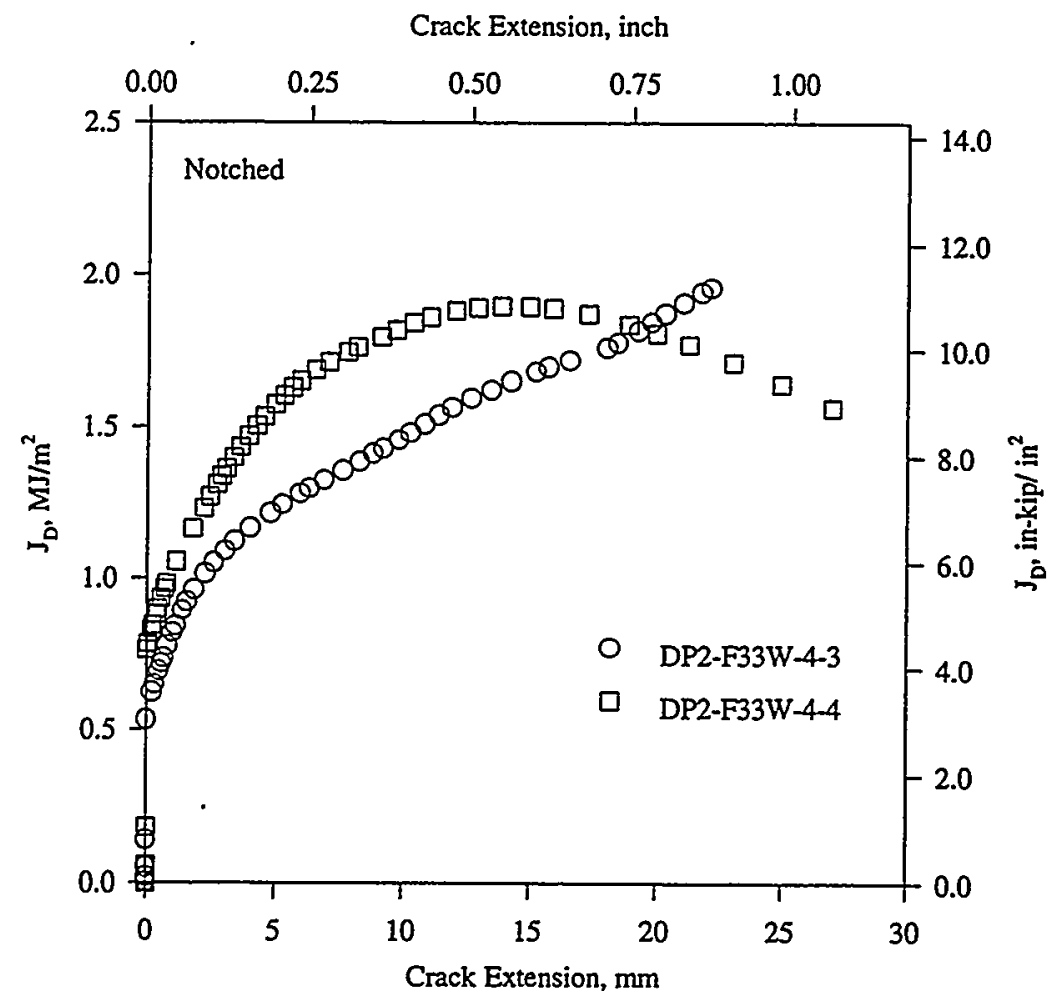

Figure 2.22 J-resistance curves for sharp-machined notch fusion-line $\mathbf{C}(\mathrm{T})$ specimens tested at $288 \mathrm{C}(\mathbf{5 5 0} \mathrm{F})$

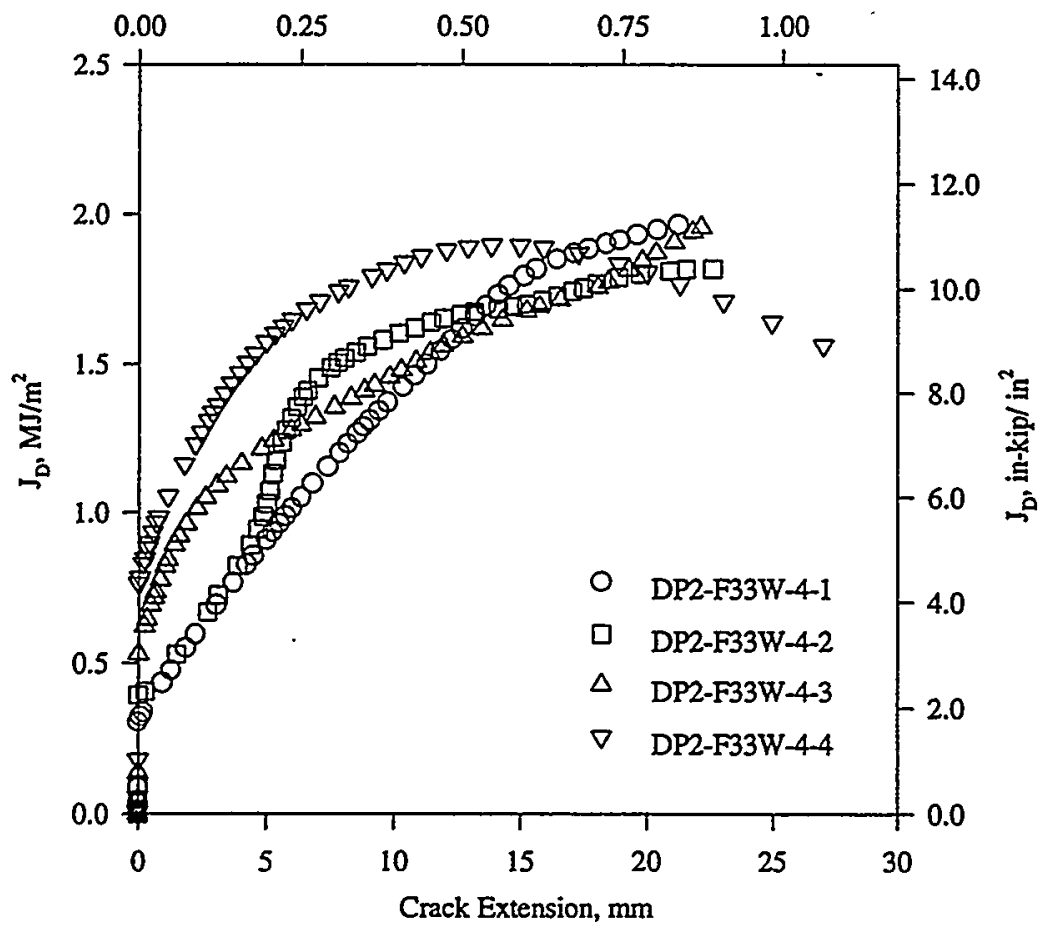

Figure 2.23 Composite J-resistance curves for bimetallic weld fusion-line $\mathbf{C}(\mathrm{T})$ specimens tested at $288 \mathrm{C}(550 \mathrm{~F})$ 


\subsection{References}

2.1 Wilkowski, G. M. and others, "Degraded Piping Program - Phase II, Significance to LeakBefore-Break and In-Service Flaw Acceptance Criteria," March 1984-January 1989, NUREG/CR-4082, Volume 8, March 1989.

2.2 Hiser, A. L. and Callahan, G. M., “A User's Guide to the NRC's Piping Fracture Mechanics Database (PIFRAC),” NUREG/CR-4894, May 1987.

2.3 Schwalbe, K. and Hellman, D., "Application of the Electric Potential Method to Crack Length Measurements Using Johnson's Formula," Journal of Testing and Evaluation, Vol. 9, No. 3, May 1981, pp. 218-221.

2.4 Marschall, C. W., Held, P. R., Landow, M. P., and Mincer, P. M., "Use of the DirectCurrent Electric Potential Method to Monitor Large Amounts of Crack Growth in Highly Ductile Metals," Fracture Mechanics: Twenty-First Symposium, ASTM STP 1074, J. P. Gudas, J. A. Joyce, and E. M. Hackett, Eds., American Society for Testing and Materials, Philadelphia, 1990, pp. 581-593.

2.5 Ernst, H. A., and Paris, P. C., "Techniques of Analysis of Load-Displacement Records by J-Integral Method," U.S. Nuclear Regulatory Commission Report NUREG/CR-1222, January 1980.

2.6 Ernst, H. A., Paris, P. C., and Landes, J. D., "Estimation of the J-Integral and Tearing Modulus T From Single Specimen Test Records," Fracture Mechanics-13th Conference, ASTM STP 743, R. Roberts, Ed., American Society for Testing and Materials, 1981, pp. 476-502. 


\section{PIPE EXPERIMENTS}

This section of the report discusses the two 914-mm (36-inch) nominal diameter, bimetallic weld, through-wall-cracked pipe experiments conducted as part of this effort. For the first experiment (1.1.1.27), no applied load data were obtained due to a failure to acquire all of the necessary ram pressure data. However, there were other data collected during this experiment that are of interest to this effort. Since the applied load data were not acquired for this first experiment, it was decided to conduct a second bimetallic weld experiment (1.1.1.28) using nominally the same test conditions as for the first pipe experiment. Excellent data were obtained for this second bimetallic weld pipe fracture experiment.

\subsection{Test Procedures}

\subsubsection{Description of Test Facility}

The test frame used for these experiments was the large pipe bend facility located at Battelle's Pressure Vessel and Piping facility at West Jefferson, Ohio. Figure 3.1 is a schematic of one of the test pipes loaded in the test facility. Figure 3.2 is a post-test photograph of the test specimen for Experiment 1.1.1.28 set up in the facility. The facility is equipped with two $2.0 \mathrm{MN}$ (450 kips) hydraulic actuators. For these experiments, the loads were to be determined by measuring the pressure on both sides of the actuators. (The pressure on the top side of the actuator was inadvertently not measured for Experiment 1.1.1.27 since it was thought that the top end of the actuator was plumbed directly to the return reservoir, which would be at atmospheric pressure. Instead it was plumbed to the return side of the servovalve such that the top end pressure was unknown and highly variable.) This method of using the actuator pressures to calculate the loads was used in lieu of load cells because the capacity of load cells was too small for the loads predicted for this experiment.

\subsubsection{Test Preparation}

The test specimens were sections of 914-mm (36-inch) nominal diameter cold-leg pipe obtained as part of the Degraded Piping Program (Ref. 3.1) from a cancelled Combustion Engineering nuclear power plant. The lengths of the actual bimetallic weld test specimens were $381 \mathrm{~mm}$ (15.0 inches) for Experiment 1.1.1.27 and $330 \mathrm{~mm}$ (13.0 inches) for Experiment 1.1.1.28. The overall lengths of the test specimens, with moment arms attached, were approximately $12.2 \mathrm{~m}$ (40 feet), see Figure 3.1. The initial machined notches were located in bimetallic welds used to join the ferritic cold-leg pipe to a stainless steel safe end. The bimetallic welds were fabricated by first buttering the bevel of the carbon steel pipe with two layers of Inconel 182 weld rod and then completing the weld using a shielded-metal-arc weld (SMAW) process using Inconel 182 weld rod. 


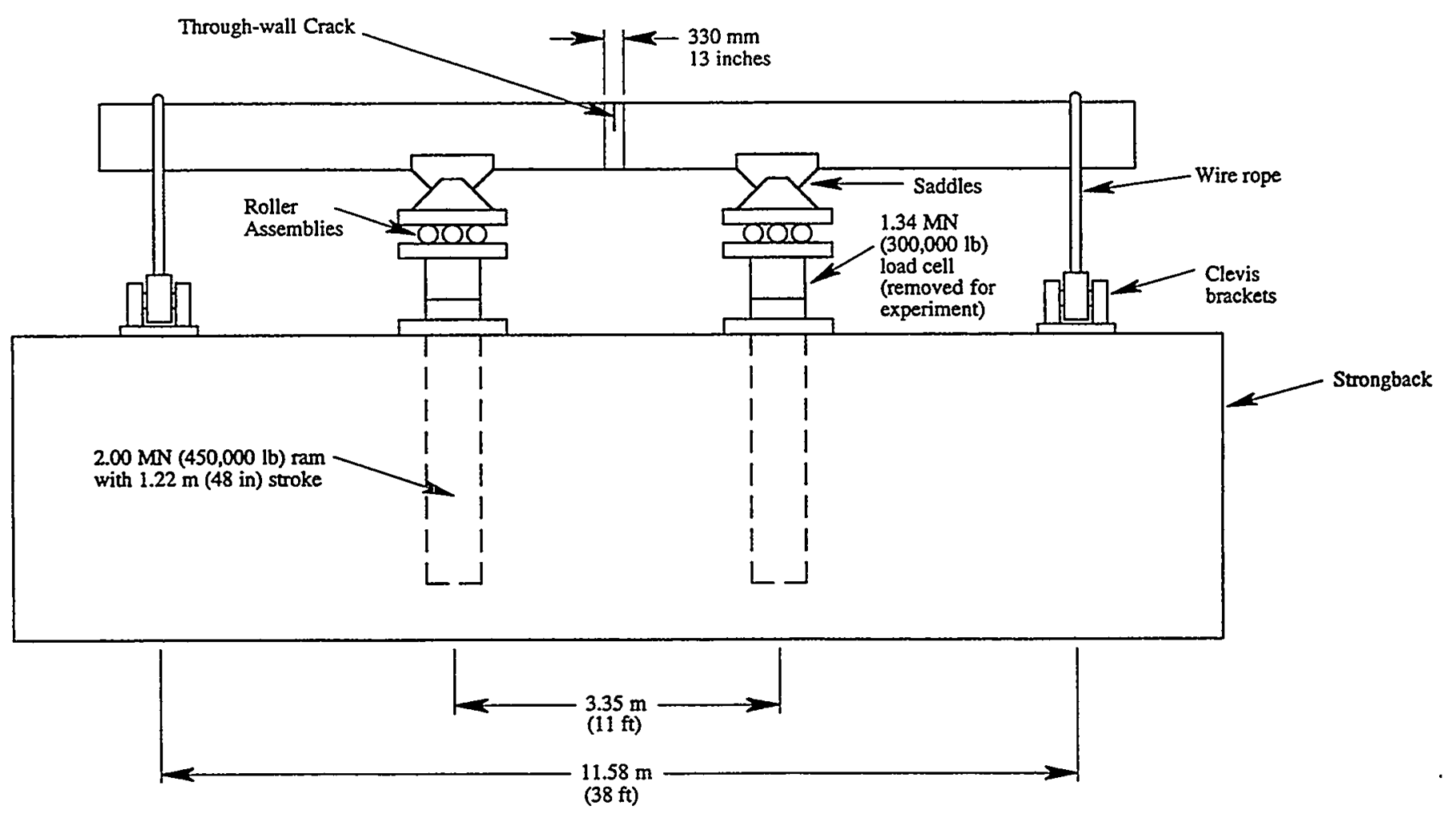

Figure 3.1 Schematic of four-point-bend strongback facility used to perform Experiments 1.1.1.27 and 1.1.1.28 


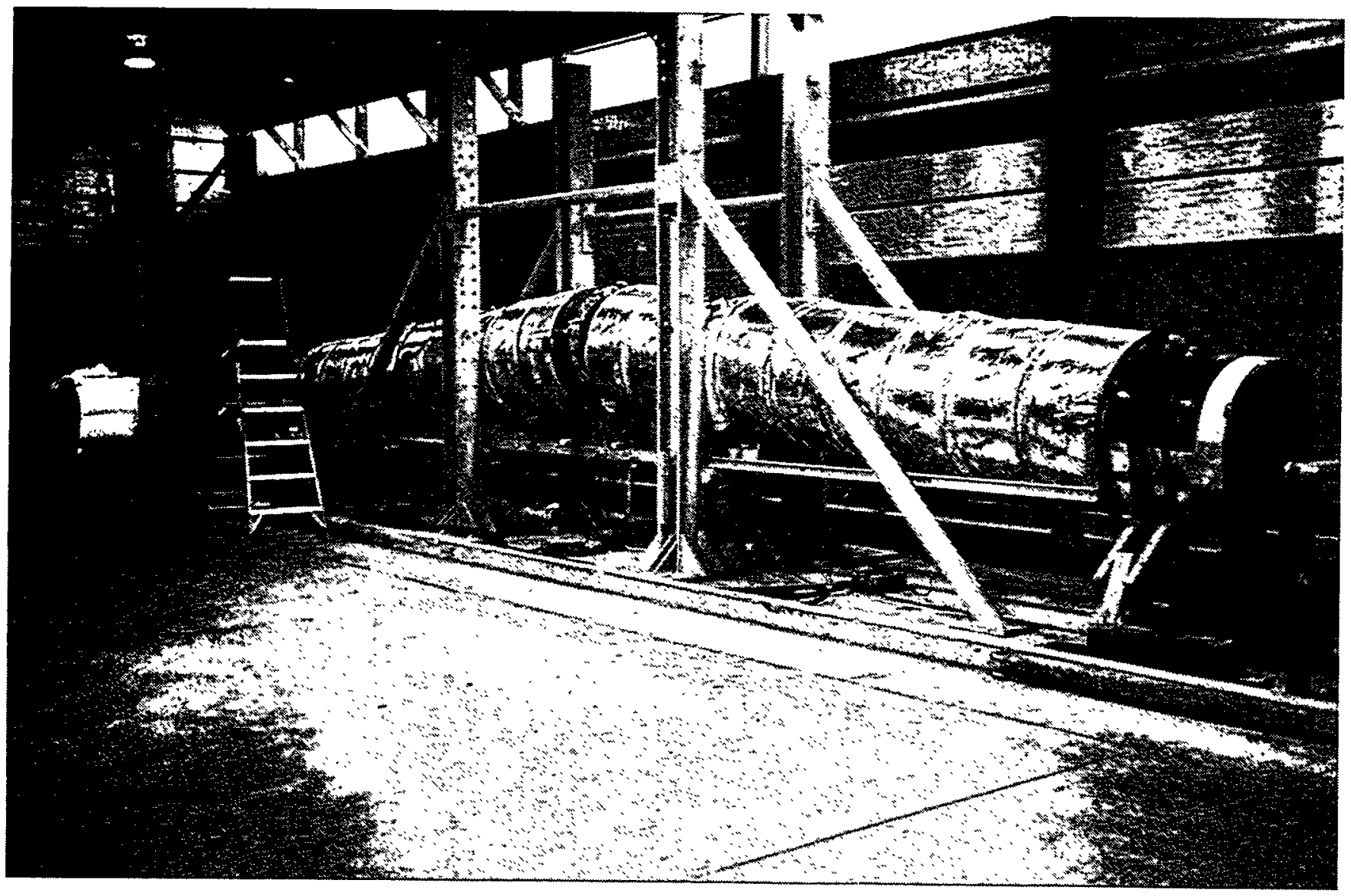

Figure 3.2 Post-test photograph of pipe specimen for Experiment 1.1.1.28 in four-point-bend facility 
The crack tips were located such that they followed the fusion line at the interface of the carbon steel pipe and the Inconel 182 weld metal. The crack tips were not fatigue precracked. Extra precautions were taken to ensure that the crack tips were actually along the fusion line. Small coupons of material were removed from the pipe wall approximately $89.5 \mathrm{~mm}$ ( 3.5 inches) back from the crack tips towards the center of the crack. These coupons were polished and etched to precisely locate the fusion line, and to establish its orientation through the thickness. These data were used in locating and orienting the final cuts of the through-wall cracks for the pipe experiments. The cracks were introduced into the welds using wire cut electric discharge machining (EDM) techniques. The overall lengths of the through-wall cracks (tip-to-tip) were nominally 37 percent of the pipe circumference. The pipe diameters and wall thicknesses on both the carbon and stainless steel sides of the welds are shown in Table 3.1.

Table 3.1 Key results for two bimetallic weld pipe fracture experiments

\begin{tabular}{|c|c|c|c|c|c|c|c|c|c|c|c|c|c|c|}
\hline \multirow{2}{*}{$\begin{array}{c}\text { Expt. } \\
\text { No. }\end{array}$} & \multicolumn{2}{|c|}{$\begin{array}{c}\text { Outside } \\
\text { Diameter, }\end{array}$} & \multicolumn{2}{|c|}{$\begin{array}{c}\text { Wall } \\
\text { Thickness, } \\
\text { mm }\end{array}$} & \multirow{2}{*}{$\begin{array}{l}\text { Crack } \\
\text { Length, } \\
2 \mathrm{c} / \pi\end{array}$} & \multicolumn{3}{|c|}{$\begin{array}{c}\text { Yield } \\
\text { Strength, } \\
\text { MPa }\end{array}$} & \multicolumn{3}{|c|}{$\begin{array}{c}\text { Ultimate } \\
\text { Strength, } \\
\text { MPa }\end{array}$} & \multirow{2}{*}{$\begin{array}{c}\mathbf{J}_{\mathbf{1}}^{(2)} \\
\mathbf{k J} / \mathrm{m}^{2} \\
\end{array}$} & \multirow{2}{*}{$\begin{array}{l}\mathbf{M}_{\mathbf{f}}^{(\mathbf{b})}, \\
\mathbf{M N - m}\end{array}$} & \multirow{2}{*}{$\begin{array}{l}M_{\max } \\
M N-m\end{array}$} \\
\hline & $\overline{\mathrm{CS}^{(c)}}$ & $s s^{(c)}$ & $\mathrm{CS}^{(\mathrm{c})}$ & $\mathrm{SS}^{(\mathrm{c})}$ & & $\mathrm{CS}^{(\mathrm{c})}$ & $\mathrm{SS}^{(\mathrm{c})}$ & Weld & $\mathrm{CS}^{(\mathrm{c})}$ & $\mathbf{S S}^{(\mathrm{c})}$ & Weld & & & \\
\hline 1.1.1.27 & 930 & 930 & 84.7 & 86.1 & 0.370 & $210^{(0)}$ & 157 & 372 & $510^{(d)}$ & 415 & 599 & 684 & N.D. ${ }^{(e)}$ & N.D. ${ }^{(c)}$ \\
\hline 1.1 .1 .28 & 927 & 921 & 85.7 & 82.6 & 0.359 & $210^{(a)}$ & 157 & 372 & $510^{(0)}$ & 415 & 599 & 684 & 6.77 & 6.95 \\
\hline
\end{tabular}

(a) The average of the two sharp machine notch specimens for the fusion line of the carbon steel pipe

and the Inconel 182 buttering passes.

(b) The average moment value at crack initiation for the two crack tips.

(c) CS = carbon steel pipe; SS = stainless steel safe end

(d) For specimens machined near the midwall position on the pipe.

(e) N.D. $=$ Not determined.

Once the flaws were introduced into the test welds and the moment arms were welded to the test specimens, the pipe specimens were set into the pipe bend facility. Once in the facility, the test specimens were instrumented. During each experiment, the following measurements were made.

- The displacement of each actuator was measured.

- The pressure on both the top and bottom of the piston for each actuator was measured. Knowing the pressures acting on and the cross sectional areas of both sides of the actuator piston, the applied load data can be calculated. (As noted earlier, pressure data were inadvertently not recorded on the top side of the actuators for Experiment 1.1.1.27. Consequently, no applied load data are available for this experiment.)

- The direct-current electric potential (d-c EP) data at the crack centerline and at each crack tip were measured. The d-c EP data were used to determine crack initiation and crack growth data. In addition, a set of reference (base metal) probes remote from the crack were attached to the external surface of the pipe. 
- Crack-mouth-opening-displacements (CMOD) at the crack centerline, midway between the crack centerline and Crack Tip B, and at each crack tip were measured. The CMOD devices at the crack centerline and midway between the crack centerline and Crack Tip B were string potentiometers. The CMOD devices at each crack tip were clip gages.

- The rotation of the pipe $559 \mathrm{~mm}$ (22.0 inches) on either side of the crack plane were measured using inclinometers.

- The displacements of the pipe relative to the outer loading points $1.68 \mathrm{~m}$ (66 inches) on either side of the crack plane, $0.61 \mathrm{~m}$ (24 inches) on either side of the crack plane, and at the crack plane were measured. (Translational measurements were made $5.79 \mathrm{~m}$ [228 inches] east of the crack plane. From these measurements, the pipe displacements at the load-points and the rotation of the pipe at these locations along the length of the pipe can be determined. The pipe displacements at the load-points are essentially the applied displacements at each actuator less the displacements due to the test machine compliance.)

- The ovalization of the pipe (top-to-bottom and side-to-side) $19 \mathrm{~mm}(0.75 \mathrm{inch})$ from the crack plane were measured using a series of string potentiometers attached to a ring mounted around the pipe. Figure 3.3 is a schematic of the ovalization device used for these pipe experiments.

- Strains on the outside surface of the pipe at 10 locations near Crack Tip A and four locations on the compressive side of the pipe were measured. (The strain data were collected only for Experiment 1.1.1.28.)

The experimental data were collected using a 486-series personal computer (PC) using a sampling rate of $0.5 \mathrm{~Hz}$. A 24 channel Racal FM tape recorder was used as a backup in the event there was a problem with the primary PC based system. Labtech Notebook data acquisition and control software was used to collect and store the data during the experiments.

\subsubsection{Loading Conditions}

The test specimens were loaded in displacement-control, four-point bending, without internal pipe pressure. The displacement rate varied during the course of the experiments from approximately 5.4 $\mathrm{mm} /$ minute ( 0.21 inches/minute) to $12.7 \mathrm{~mm} /$ minute $(0.5$ inches/minute). The inner and outer spans for the four-point bending were $3.35 \mathrm{~m}$ (11 feet) and $11.58 \mathrm{~m}$ (38 feet), respectively. The test temperature was $288 \mathrm{C}(550 \mathrm{~F})$ for both experiments. 


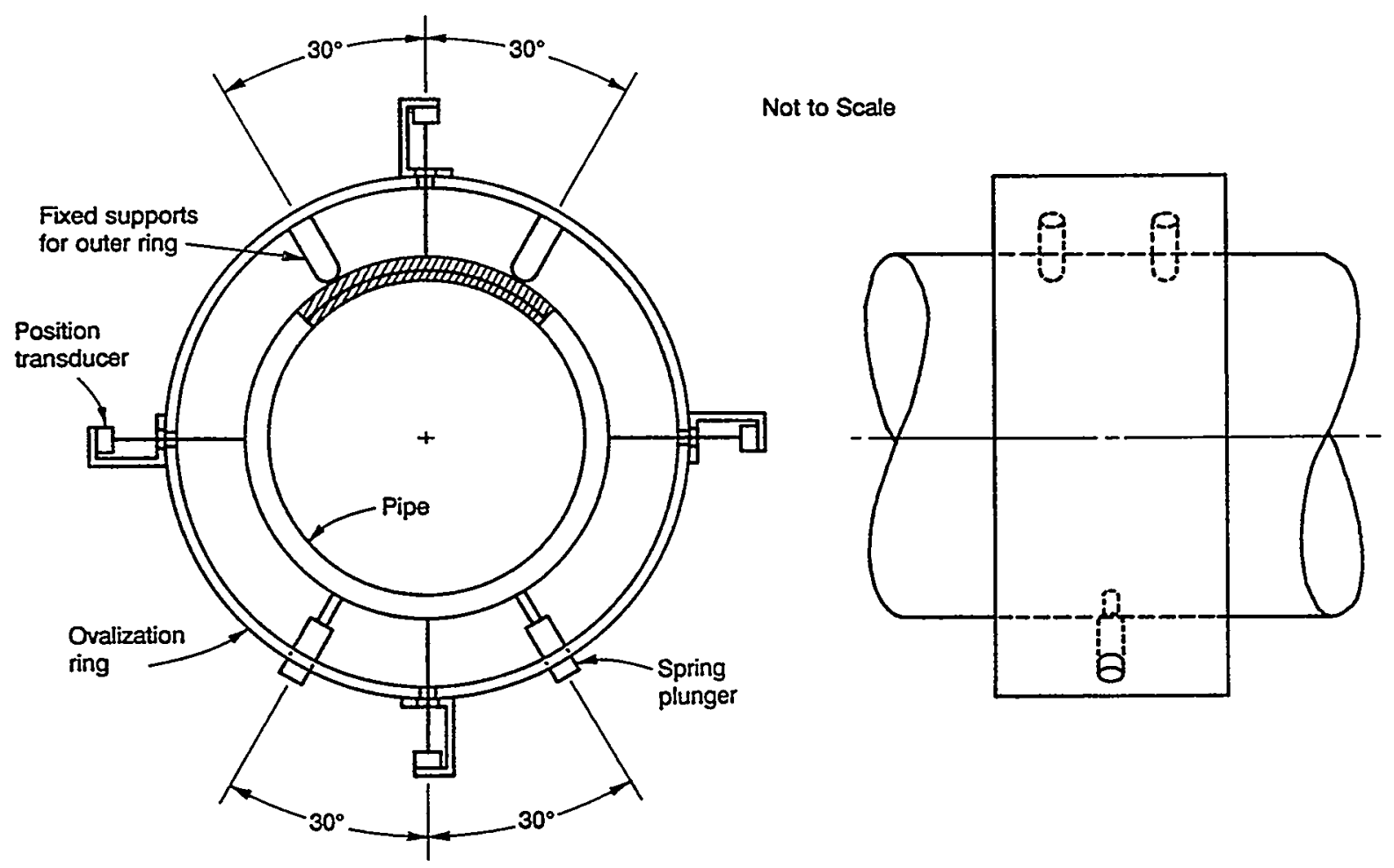

Figure 3.3 Schematic of ovalization device used for Experiments 1.1.1.27 and 1.1.1.28

\subsection{Test Results}

The key results from these pipe fracture experiments are presented in this section of the report. A summary of the key results for these two experiments is presented in Table 3.1. Included in Table 3.1 are the pipe dimensions, crack size, material property data (i.e., yield and ultimate strengths for both the stainless and carbon steel base metals as well as the Inconel weld metal, and the $\mathrm{J}_{\mathrm{i}}$ value for the fusion line at the interface of the carbon steel pipe bevel and the Inconel 182 buttering passes from a $C(T)$ specimen test), and moments at crack initiation and maximum load for Experiment 1.1.1.28 only.

Figure 3.4 is a plot of the applied load as a function of the pipe displacement at the load point for Experiment 1.1.1.28. The applied load data shown in this figure have been corrected for the deadweight load distribution of the pipe. The dead-weight load for this experiment was calculated by determining the static moment applied at the crack by the actual dead-weight load distribution along the pipe length. Using the moment arm length, an equivalent applied load ("dead-weight" load) at each actuator was determined and added to the applied load data calculated from the actuator pressure data. The pipe displacements shown in this figure, and reported throughout this report, are the 
measured pipe displacements corrected for the test machine compliance. Therefore, the displacements shown are those due solely to the cracked pipe. From Figure 3.4 it can be seen that the maximum applied load for this experiment was $3.38 \mathrm{MN}$ (759.9 kips).

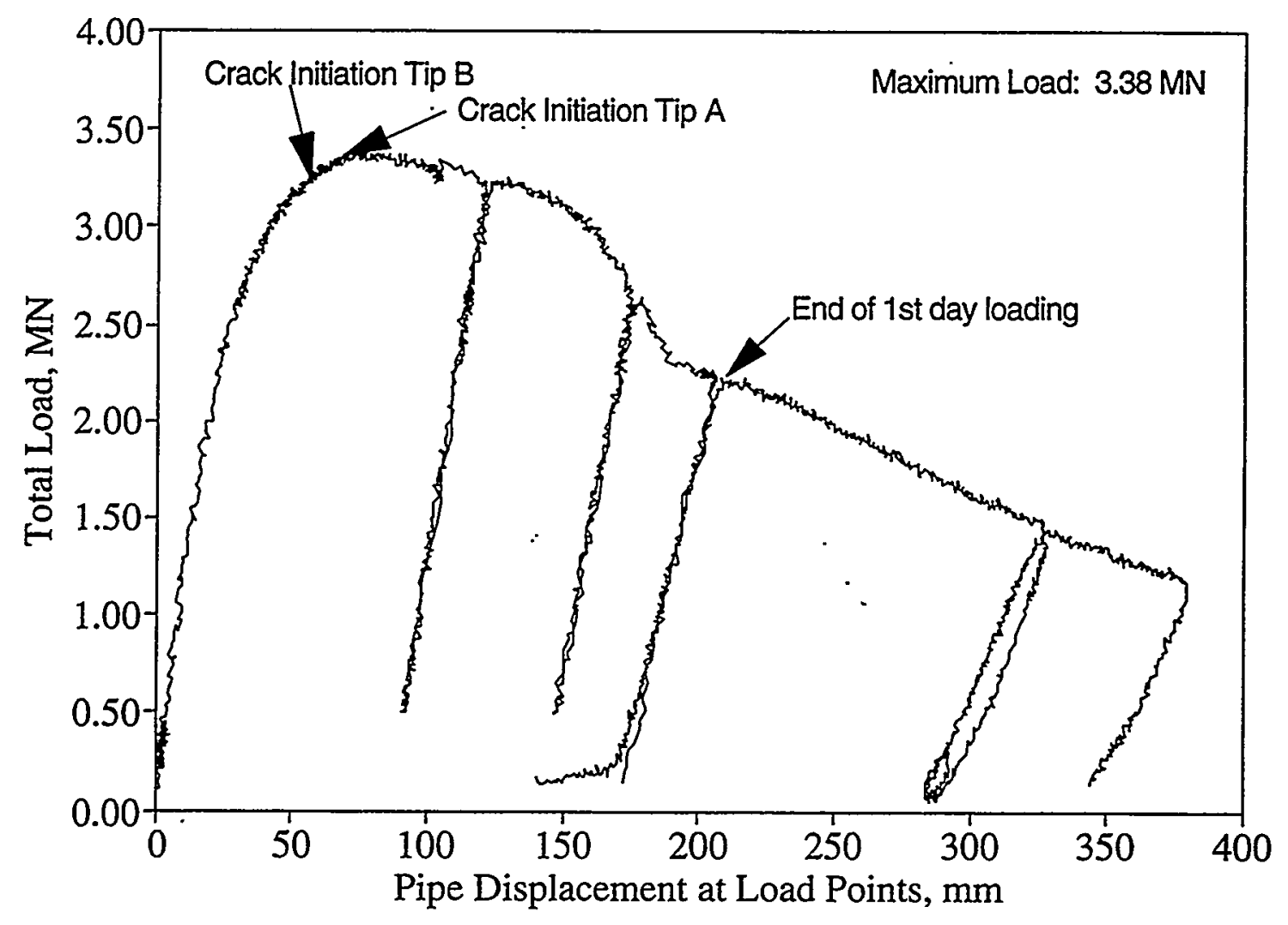

Figure 3.4 Load as a function of pipe displacement at the load point for Experiment 1.1.1.28 
Figure 3.5 is a plot of the crack section rotation data as a function of the pipe displacement data for the two experiments. Figure 3.5a shows the data for Experiment 1.1.1.27, and Figure 3.5b shows the data for Experiment 1.1.1.28. Pipe rotations were determined using two methods. The first method used the beam device attached to the pipe near the outer load points. String potentiometers measured vertical displacements at various locations along the pipe relative to the outer load points. A schematic of this beam device is shown in Figure 3.6. The relative pipe displacements were measured at the crack plane, $610 \mathrm{~mm}$ (24 inches) on either side of the crack plane, and at the load points, i.e., $1.676 \mathrm{~m}$ (66 inches) on either side of the crack plane. The rotation of the pipe was then determined based on the known, fixed distances between the string potentiometers and the relative vertical displacements between the pipe and the beam. The set of string potentiometers at the crack and those $610 \mathrm{~mm}$ ( 24 inches) from the crack plane resulted in a measure of the effective rotation of pipe $305 \mathrm{~mm}$ (12 inches) from the crack plane. The set of string potentiometers $610 \mathrm{~mm}$ ( 24 inches) from the crack plane and those $1.676 \mathrm{~m}$ (66 inches) from the crack plane resulted in a measure of the effective pipe rotation $1.143 \mathrm{~m}$ (45 inches) from the crack plane. A second method to determine rotation was to use the inclinometers located $559 \mathrm{~mm}$ (22 inches) on either side of the crack plane. From Figure 3.5 it can be seen that for a given pipe displacement, the amount of rotation for the two experiments was comparable.

Figure 3.7 is a plot of the crack section moment data as a function of the crack-section rotation data for Experiment 1.1.1.28. The moment data were calculated from the applied load data using Equation 3-1.

$$
\mathrm{M}=(\mathrm{P} / 2)[(\mathrm{z}-\mathrm{L}) / 2]
$$

where

$$
\begin{aligned}
\mathrm{M}= & \text { Applied moment, } \\
\mathrm{P}= & \text { Total applied load (including the equivalent "dead-weight" load } \\
& \text { from the dead-weight moment) } \\
\mathrm{z}= & \text { Four-point bend outer span, and } \\
\mathrm{L}= & \text { Four-point bend inner span. }
\end{aligned}
$$

The rotation data shown in Figure 3.7 are based on measurements from the inclinometers and are the total rotation angle $(2 \phi)$, see Figure 3.7. (The total rotation angle $(2 \phi)$ is a measure of the rotation angle of the two ends of the deflected pipe to each other.) The maximum moment for this experiment was 6.95 $\mathrm{MN}$-m (61,550 in-kips).

Figure 3.8 is a plot of the d-c EP data at each crack tip as a function of the corresponding crackmouth-opening-displacement at each crack tip for both experiments. Figures $3.8 \mathrm{a}$ and $3.8 \mathrm{~b}$ show the data for Experiment 1.1.1.27, and Figures 3.8c and 3.8d show the data for Experiment 1.1.1.28. From these data it was possible to determine the instant of crack initiation at each crack tip. Crack initiation is defined as that instant when the slope of the d-c EP versus CMOD curve first starts to increase. From Figures 3.8a and 3.8b, it can be seen that for Experiment 1.1.1.27, Crack Tip A initiated at a CMOD value of $0.21 \mathrm{~mm}$ ( 0.008 inches), and Crack Tip B initiated at a CMOD value of $0.39 \mathrm{~mm}$ (0.015 inches). From Figures $3.8 \mathrm{c}$ and $3.8 \mathrm{~d}$, it can be seen that for Experiment 1.1.1.28, 


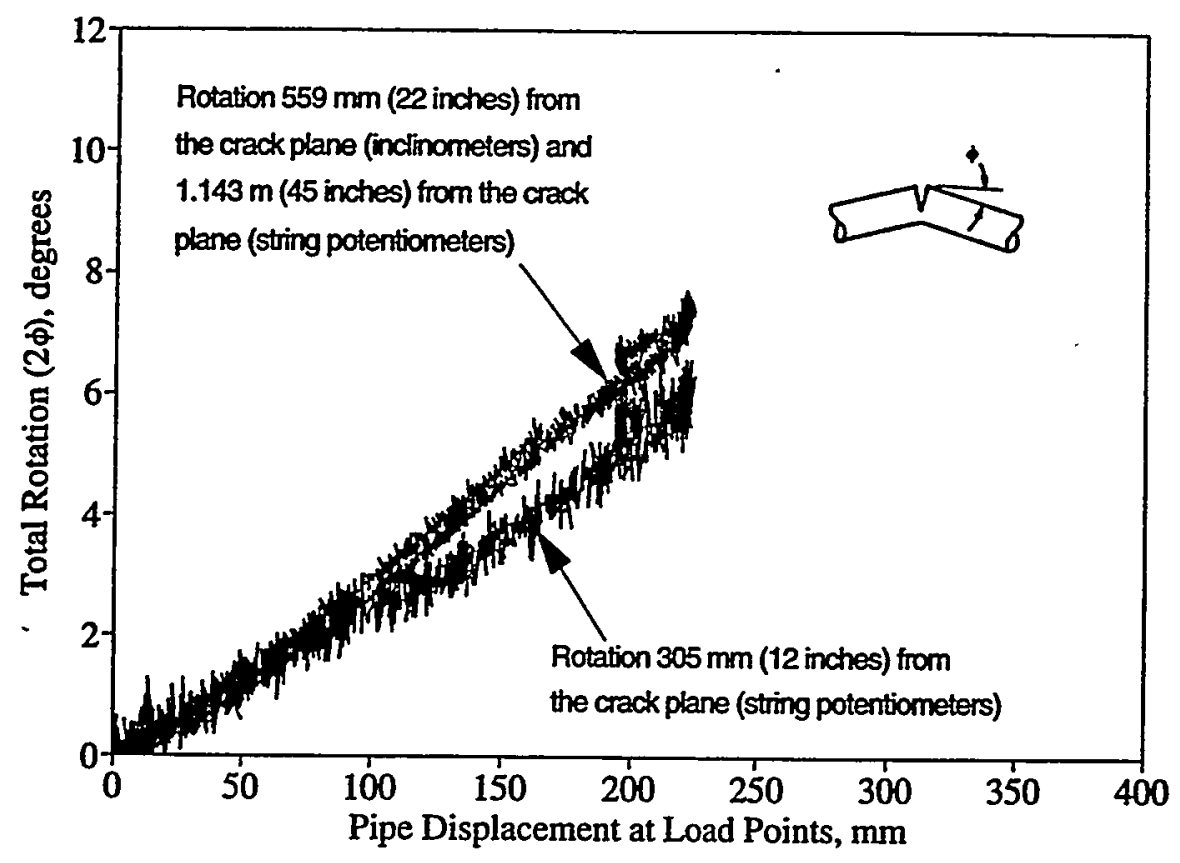

(a) Experiment 1.1.1.27

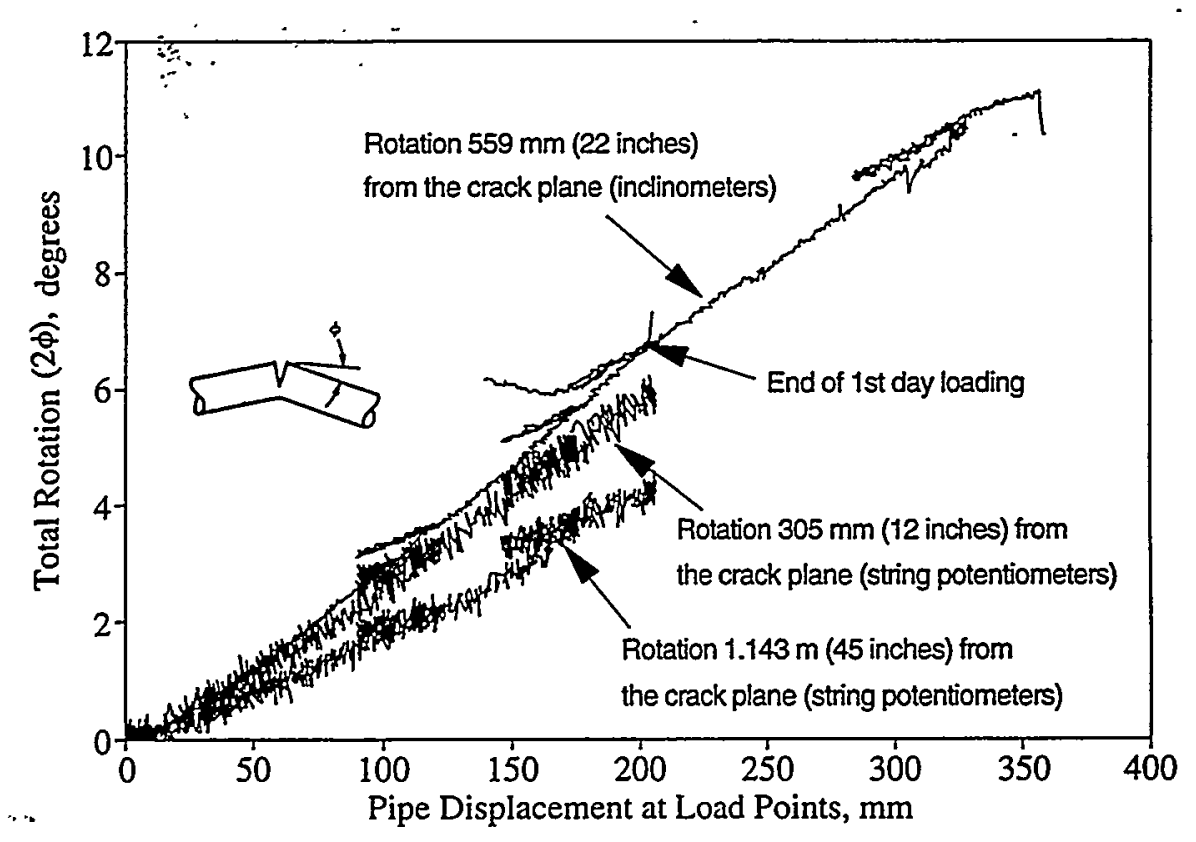

(b) Experiment 1.1.1.28

Figure 3.5 Rotation as a function of pipe displacement at the load point 


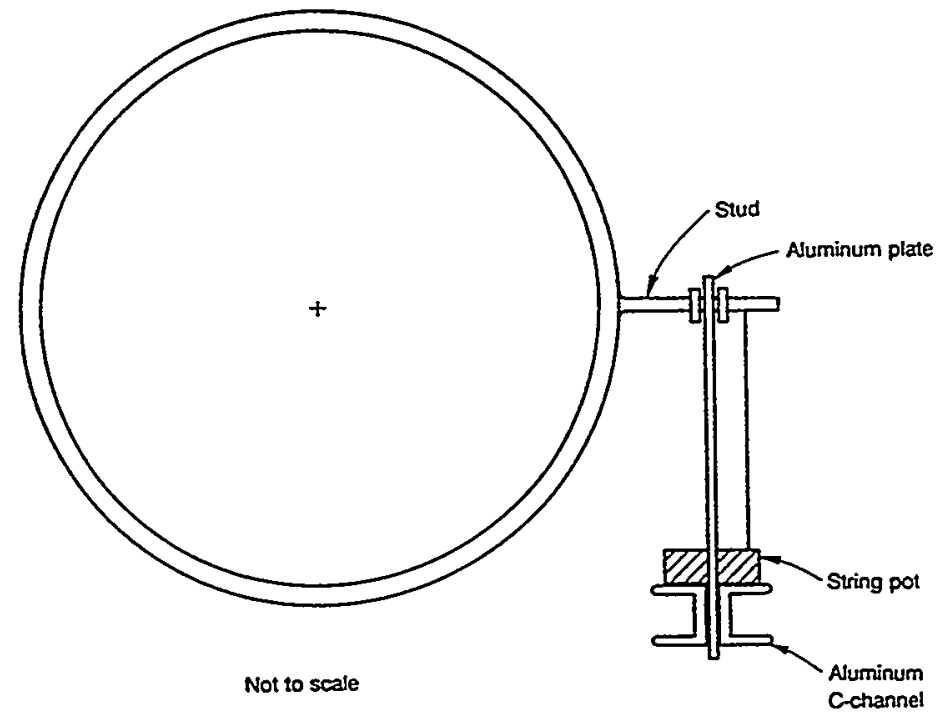

(a) End View

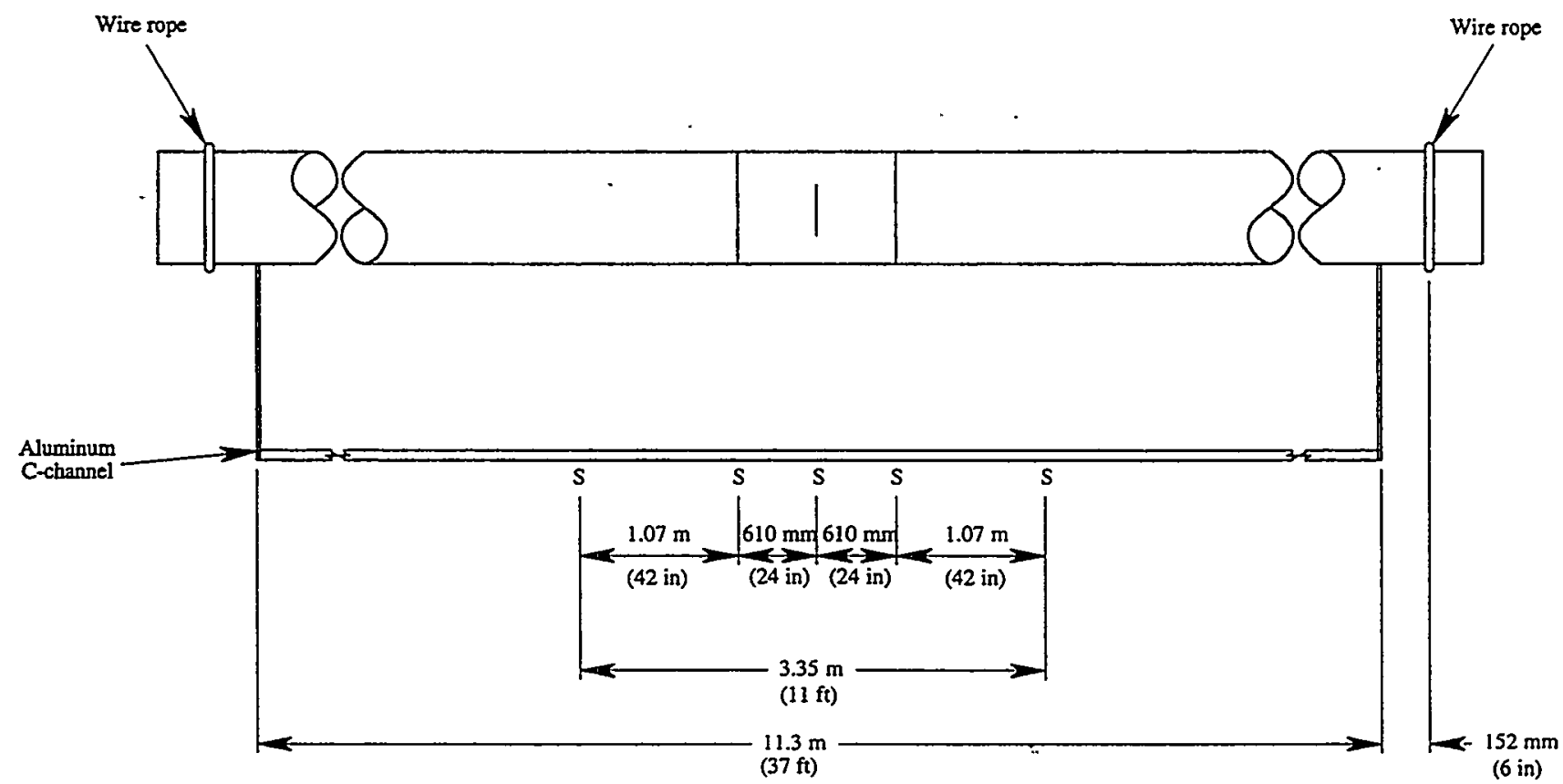

(b) Side View

Figure 3.6 Schematic of the beam device used to measure rotations during Experiments 1.1.1.27 and 1.1.1.28 


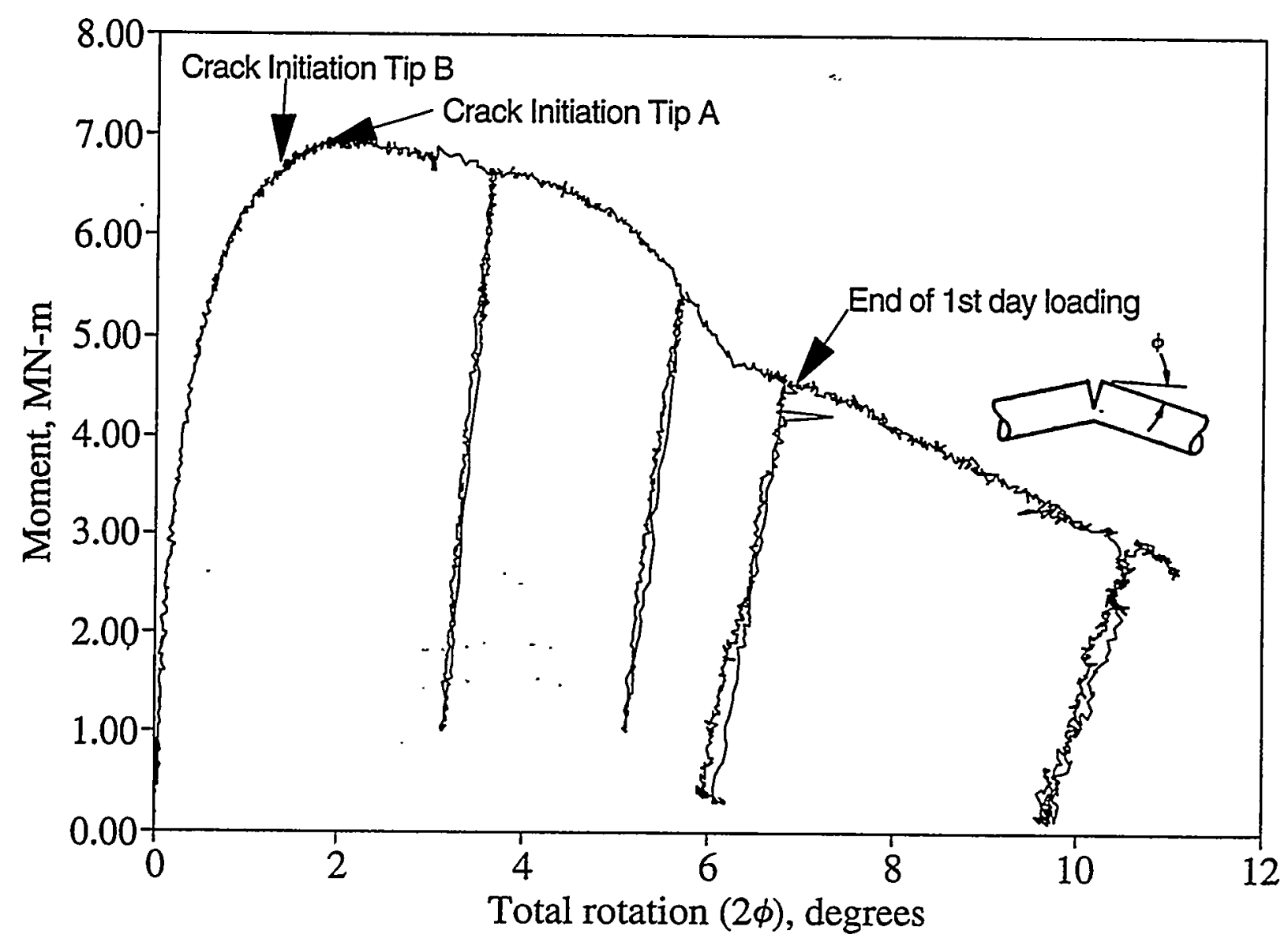

Figure 3.7 Moment as a function of total rotation (2 $\phi$ ) for Experiment 1.1.1.28 


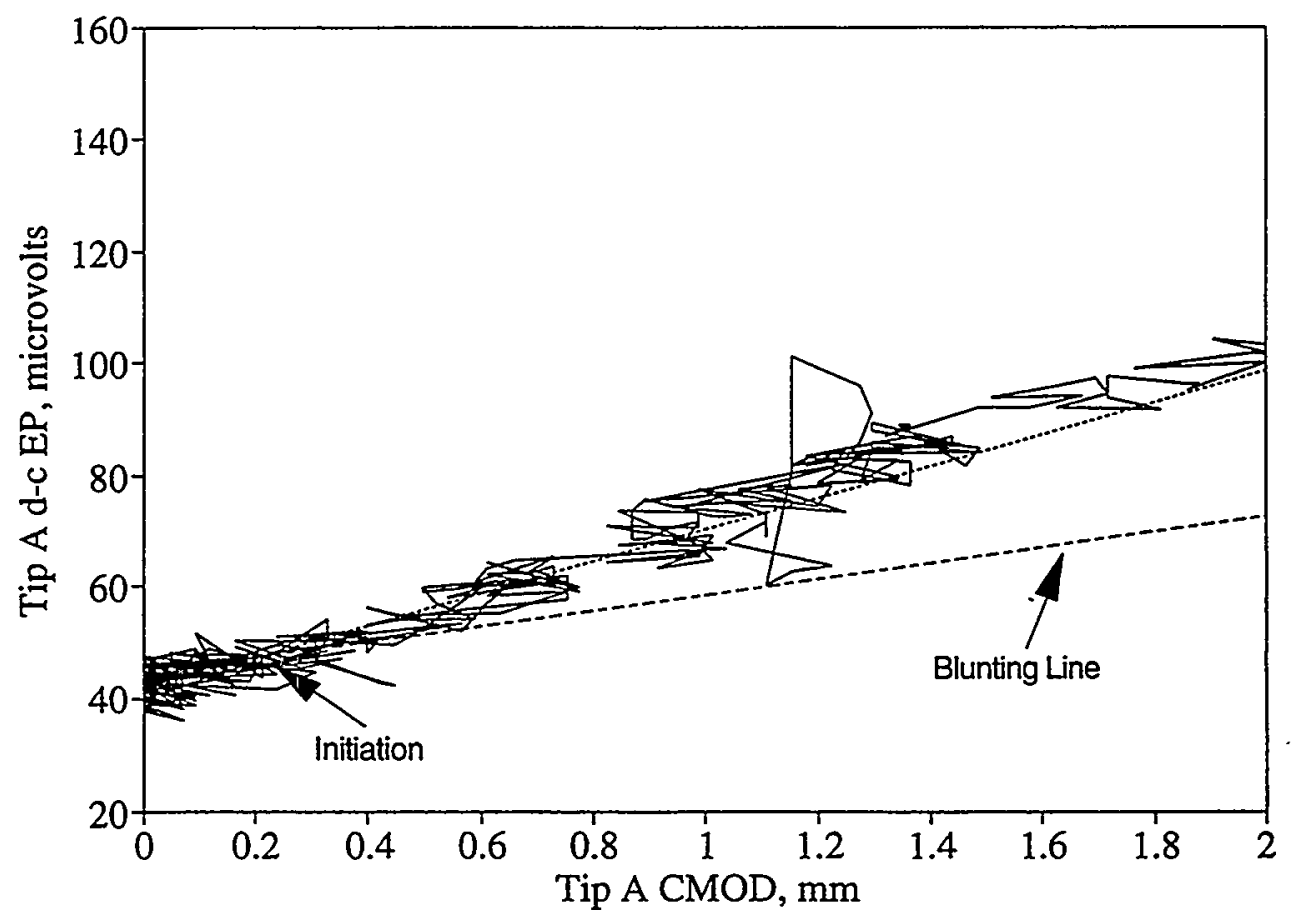

(a) Crack Tip A Experiment 1.1.1.27

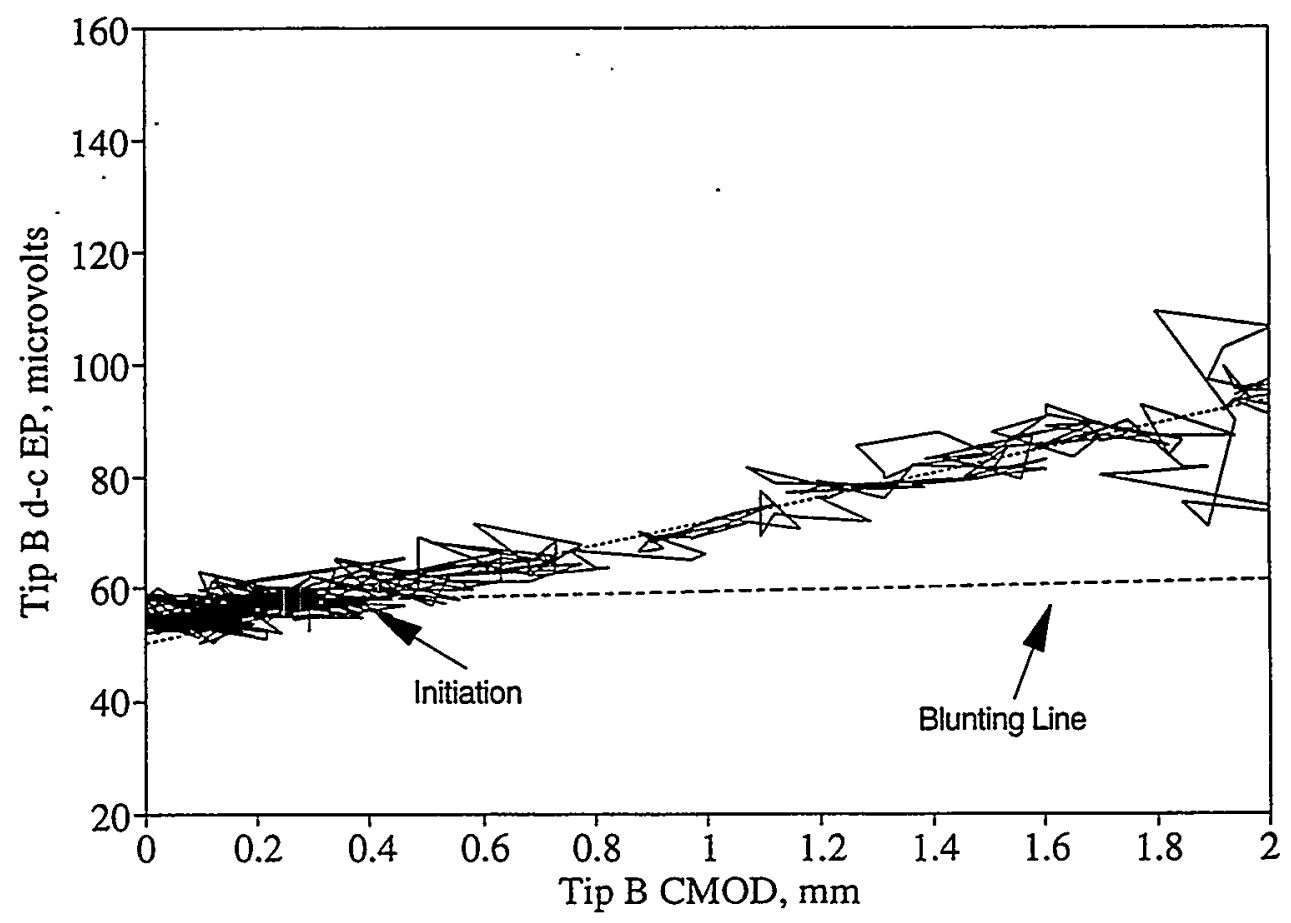

(b) Crack Tip B Experiment 1.1.1.27

Figure 3.8 d-c electric potential as a function of corresponding crack tip CMOD used to determine crack initiation 


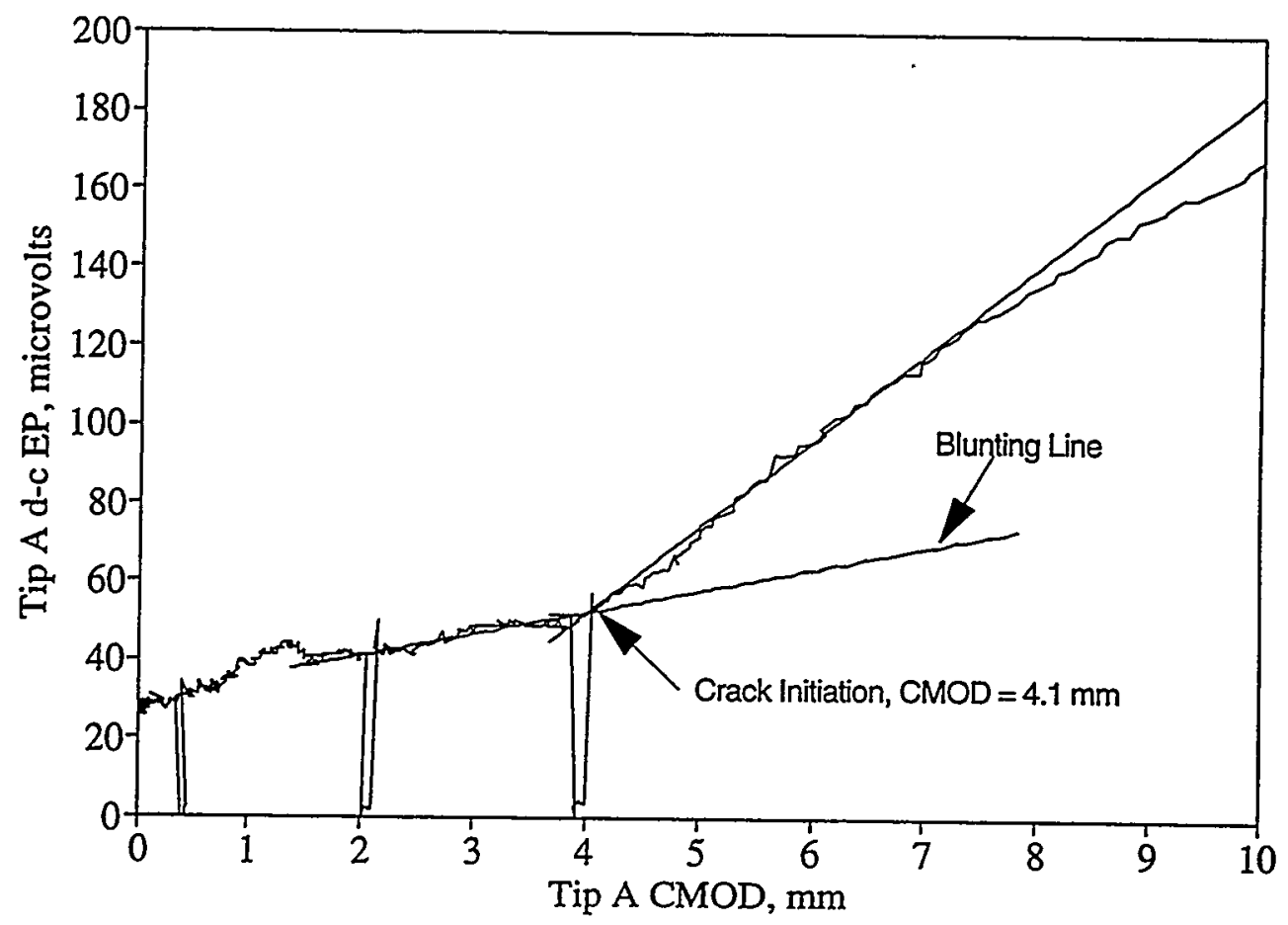

(c) Crack Tip A Experiment 1.1.1.28

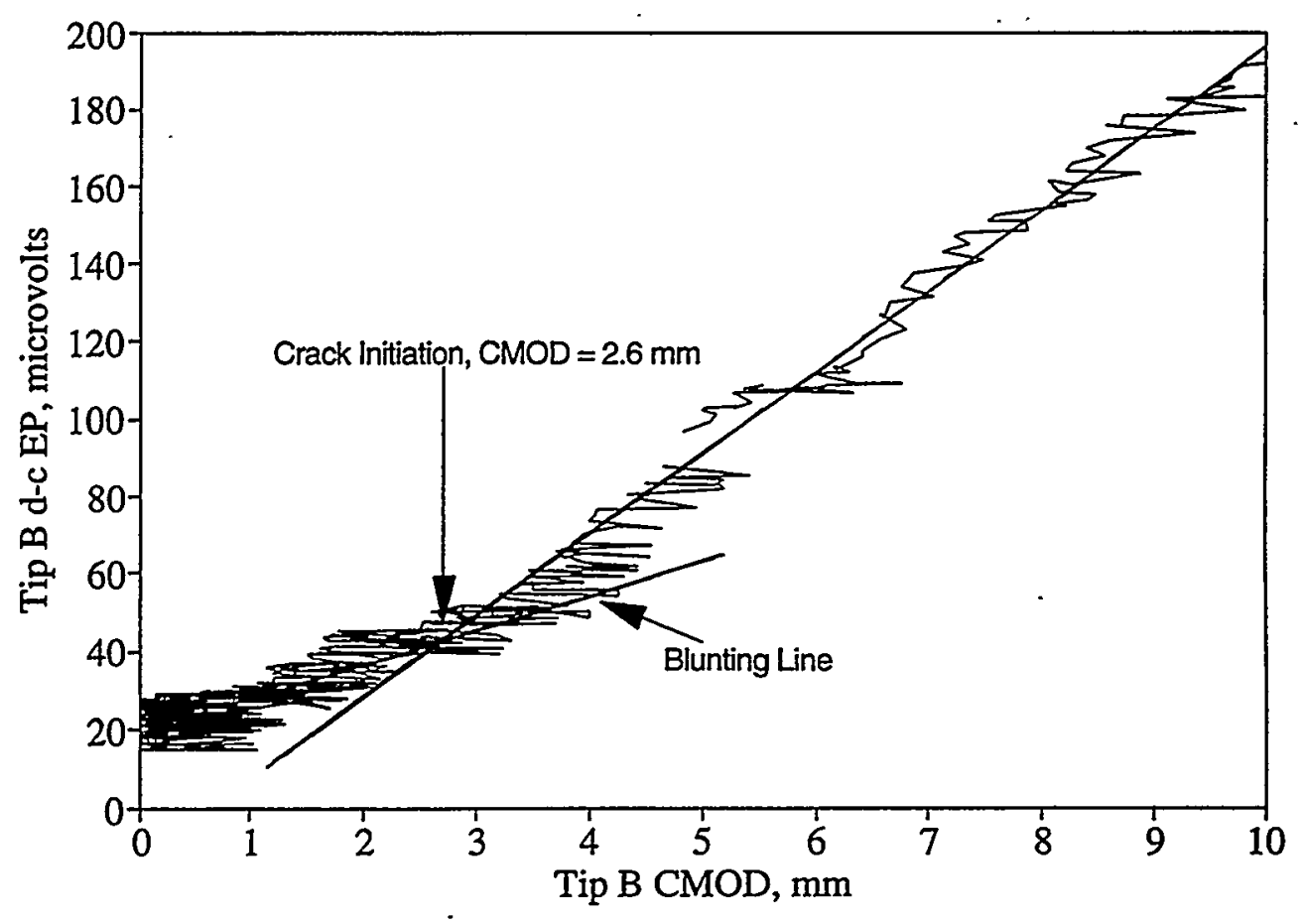

(d) Crack Tip B Experiment 1.1.1.28

Figure 3.8 Continued 
Crack Tip A initiated at a CMOD value of $4.1 \mathrm{~mm}$ ( 0.16 inches), and Crack Tip B initiated at a CMOD value of $2.6 \mathrm{~mm}$ ( 0.10 inches). The difference between the CMOD values at the crack tips at crack initiation between the two experiments is that in Experiment 1.1.1.27 the clip gages were close to the crack tips, but in Experiment 1.1.1.28 the clip gages were closer to the center of the crack.

Figure 3.9 is a plot of the CMOD data at the crack centerline, midway between the crack centerline and Crack Tip B, and both crack tips as a function of pipe displacement at the load point. Figure 3.9a presents the data for Experiment 1.1.1.27, and Figure 3.9b presents the data for Experiment 1.1.1.28. The data in Figure 3.9 can be used to assess crack-opening-area calculations for leak-rate predictions.

From Figures 3.8c, 3.8d, and 3.9b, it can be seen that for Experiment 1.1.1.28 the CMOD at the crack centerline when the through-wall crack initiated was $22.3 \mathrm{~mm}(0.88$ inch) at Crack Tip A and $15.5 \mathrm{~mm}(0.61 \mathrm{inch})$ at Crack Tip B. Thus, it appears that the crack initiated first at Crack Tip B. Figure 3.10 is a plot of the crack section moment data as a function of the crack centerline crackmouth-opening-displacement data for Experiment 1.1.1.28. From Figure 3.10 it can be seen that Crack Tip A initiated at a moment value of $6.89 \mathrm{MN}-\mathrm{m}$ (61,000 in-kips) while Crack Tip B initiated at a moment value of $6.64 \mathrm{MN}-\mathrm{m}$ (58,800 in-kips). The average of these two moment values is 6.77 MN-m (59,900 in-kips), which is approximately 97 percent of the maximum moment for the experiment, i.e., $6.95 \mathrm{MN}-\mathrm{m}(61,550$ in-kips).

Figure 3.11 presents photographs of the crack growth at each crack tip for both experiments. Figures $3.11 \mathrm{a}$ and $3.11 \mathrm{~b}$ are photographs of the crack growth at Crack Tips A and B, respectively, for Experiment 1.1.1.27. Figures 3.11c and 3.11d are photographs of the crack growth at Crack Tips A and $B$, respectively, for Experiment 1.1.1.28.

Figure 3.12 is a plot of the through-wall-crack growth data as a function of the pipe displacement at the actuator for the two experiments. The results are in good agreement between the two tests. The through-wall-crack growth data were calculated from the crack centerline d-c EP data for Experiment 1.1.1.27 and from the pipe displacement at the load-point data using the following empirical expression for Experiment 1.1.1.28.

$$
\Delta \mathrm{a}=-227.619+4.395 \Delta-0.0125 \Delta^{2}+1.4 \times 10^{-5} \Delta^{3}
$$

where

$\Delta \mathrm{a}$ is the average crack growth at one crack tip in mm, and

$\Delta$ is the pipe displacement at the load point in $\mathrm{mm}$.

(Note: it was necessary to resort to the empirically derived crack-growth expression based on pipedisplacement data for estimating the crack growth for Experiment 1.1.1.28 since the crack centerline d-c EP data for that experiment were not good.)

The through-wall-crack growth data shown in Figure 3.12 are the average crack growth for one crack tip. 


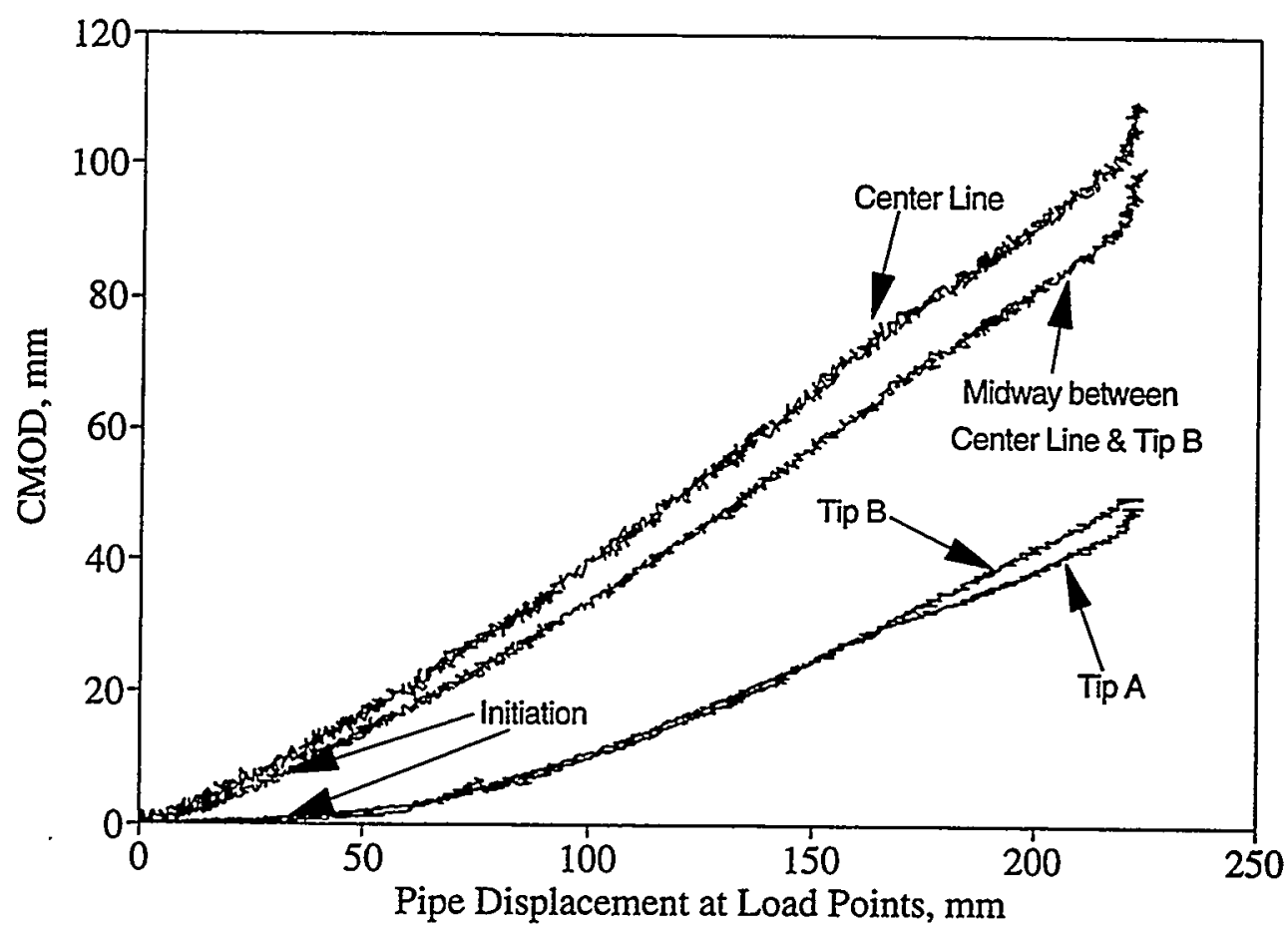

(a) Experiment 1.1.1.27

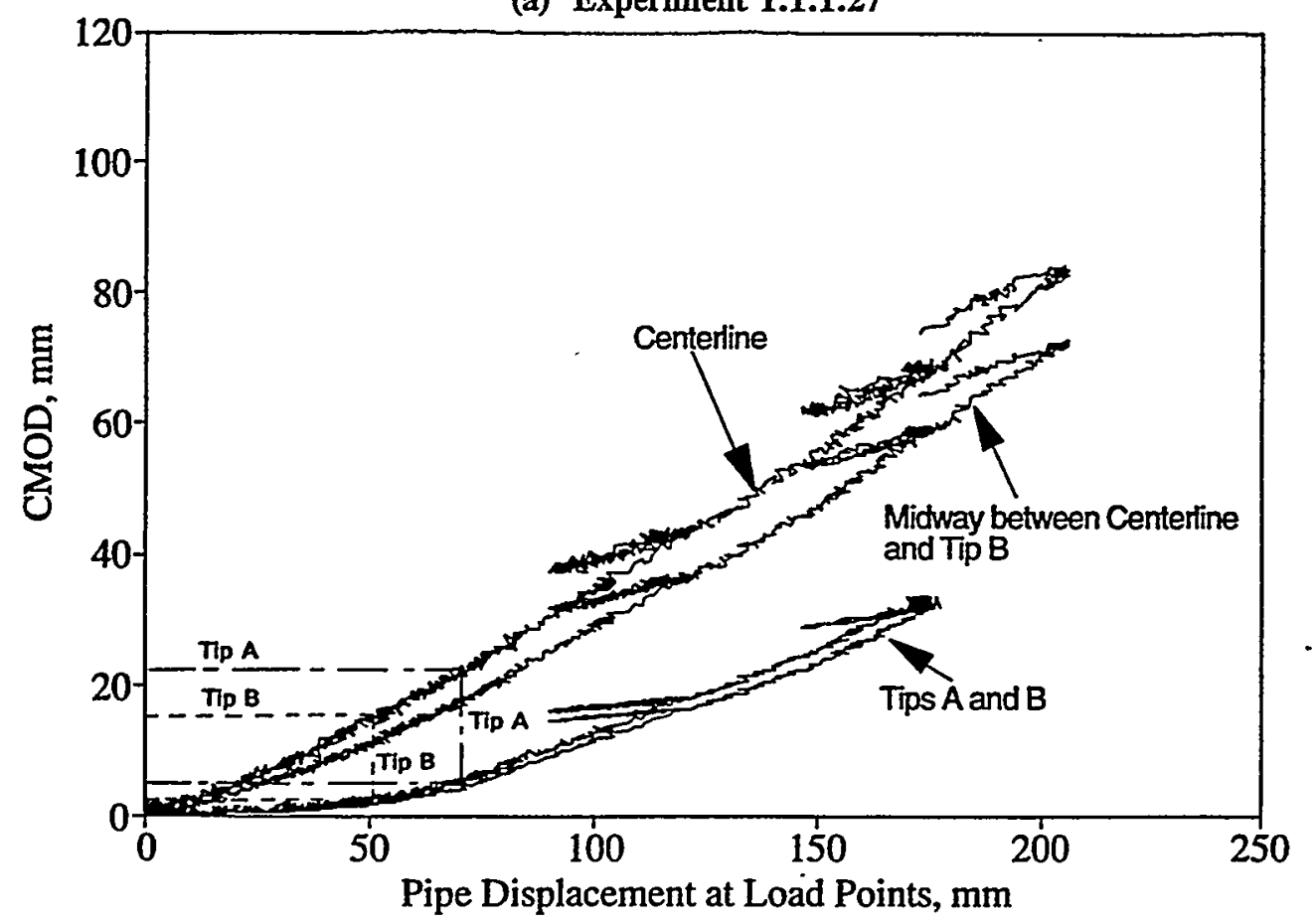

(b) Experiment 1.1.1.28

Figure 3.9 Centerline, midway between centerline and Crack Tip B, Crack Tip A, and Crack Tip B crack-mouth-opening displacements as a function of the pipe displacement at the load point 


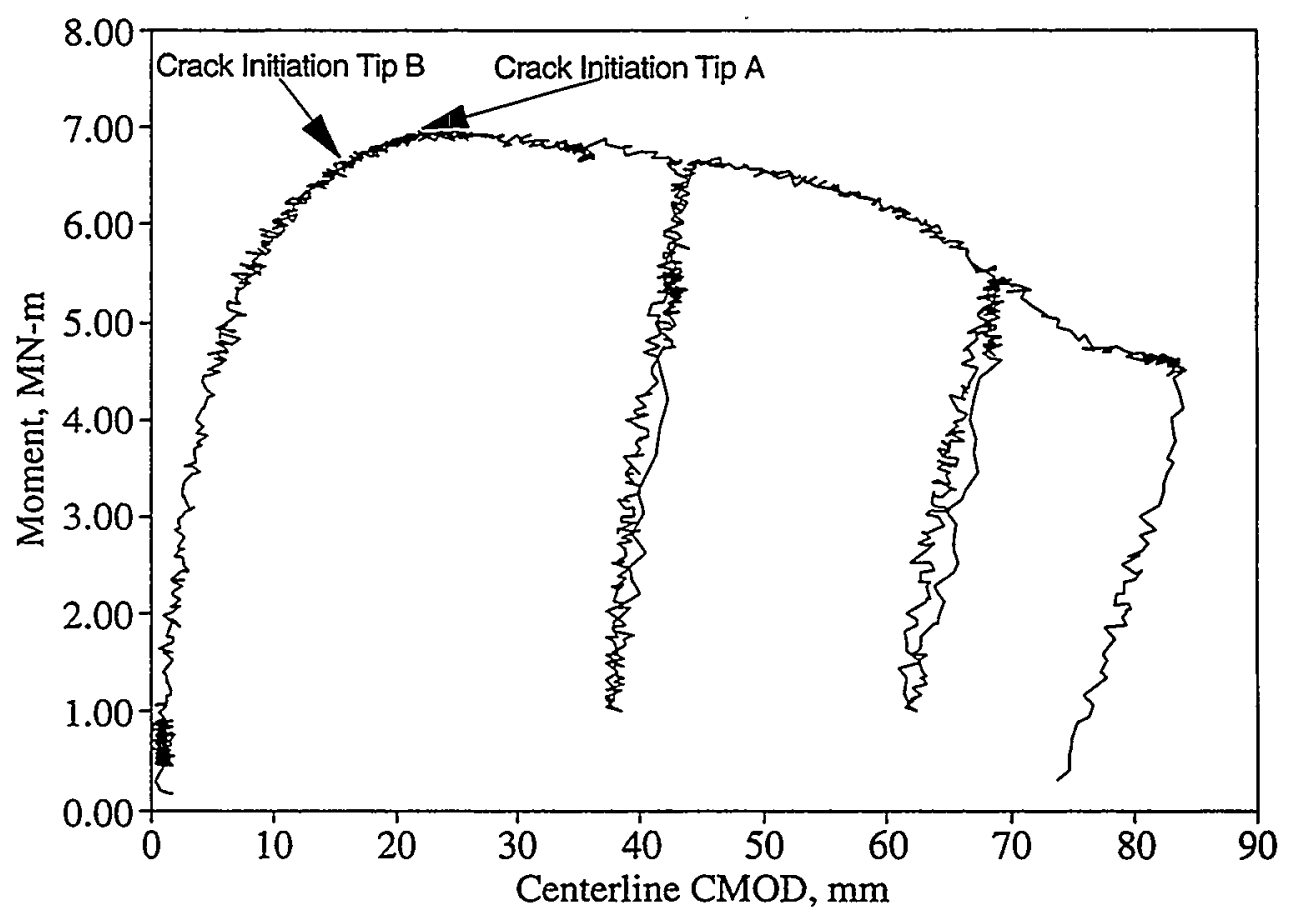

Figure 3.10 Moment as a function of crack centerline CMOD for Experiment 1.1.1.28 


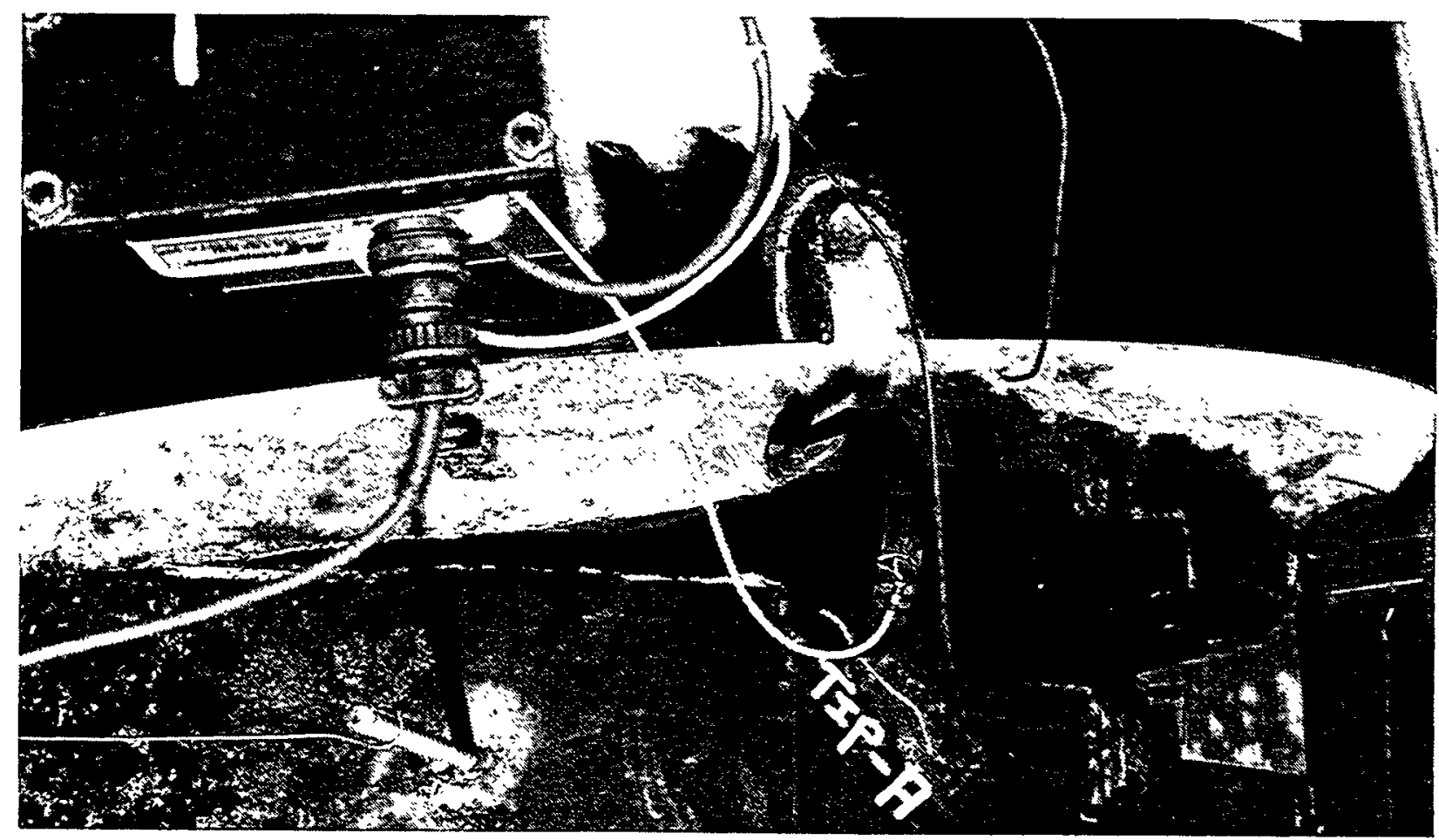

(a) Experiment 1.1.1.27 Crack Tip A

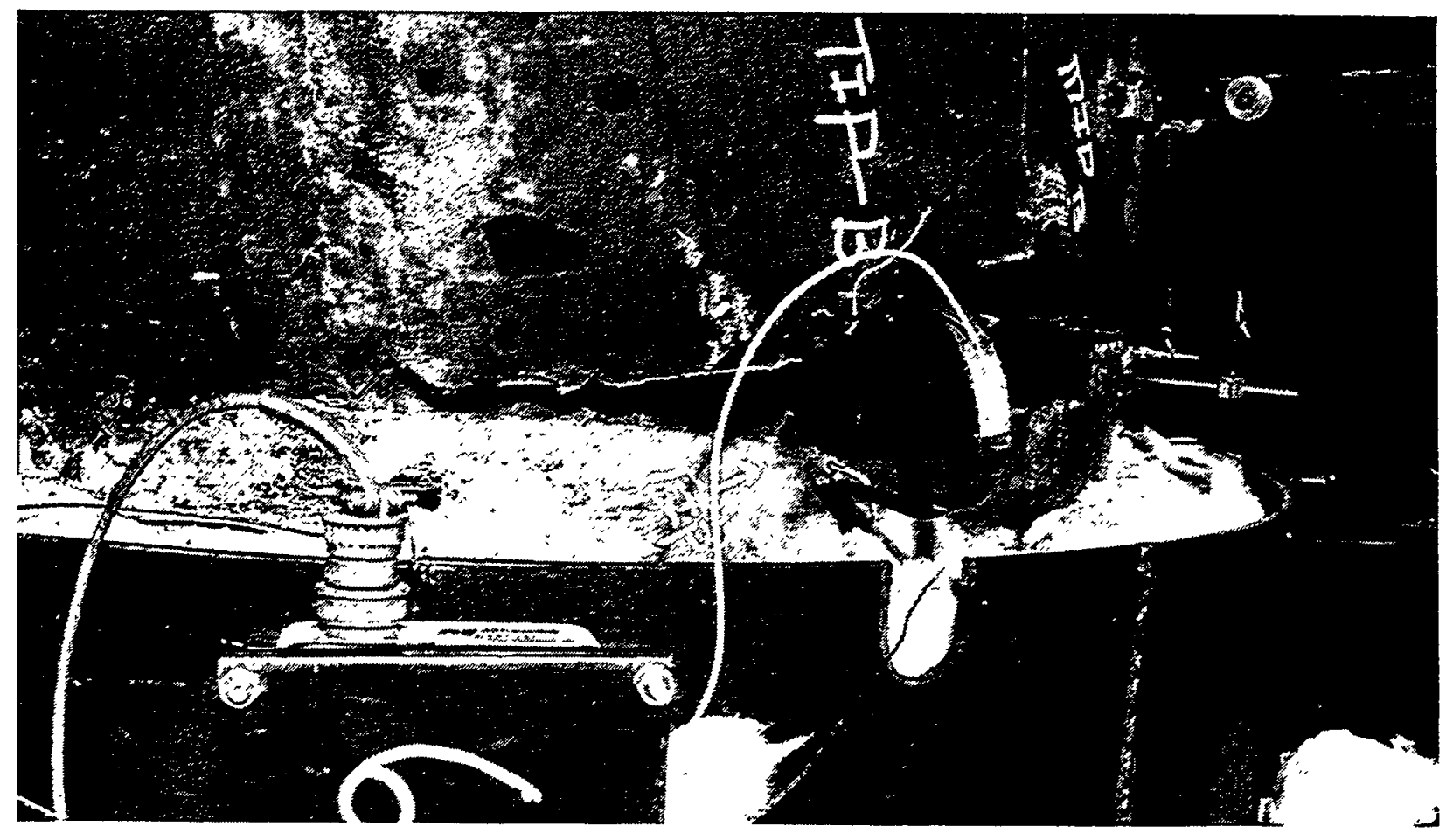

(b) Experiment 1.1.1.27 Crack Tip B

Figure 3.11 Photographs of crack growth 


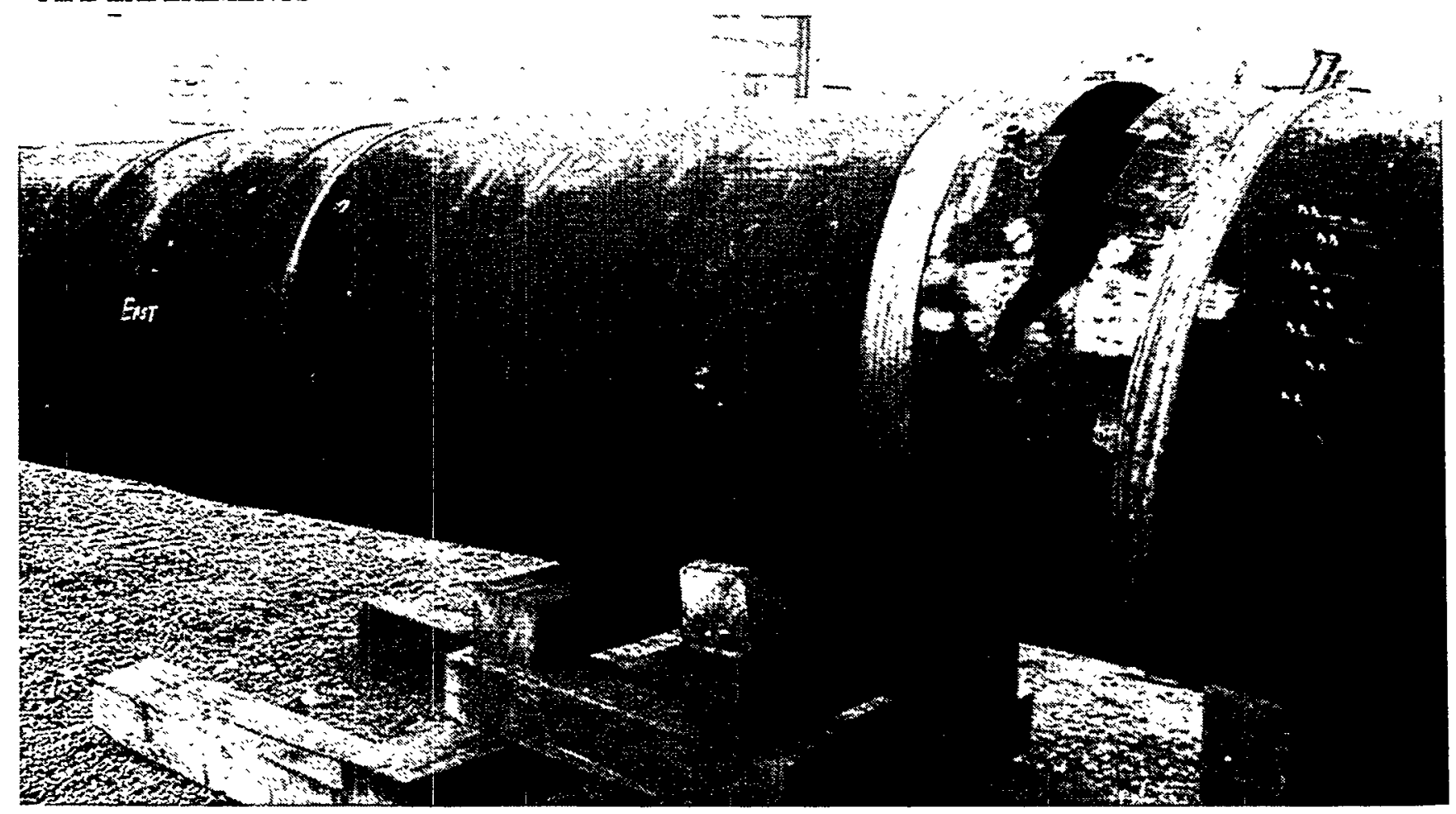

(c) Experiment 1.1.1.28, Crack Tip A

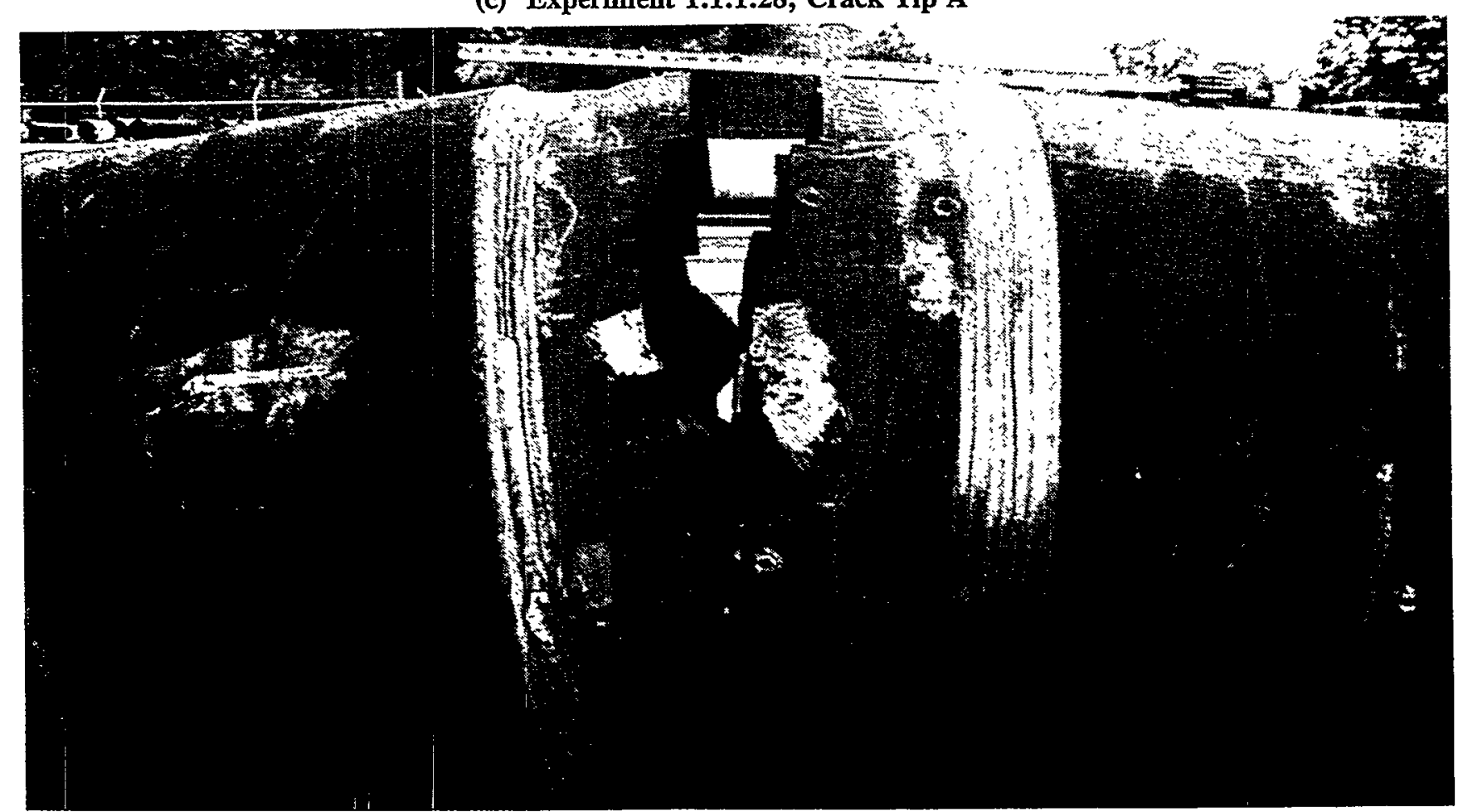

(d) Experiment 1.1.1.28, Crack Tip B

Figure 3.11 (continued) 


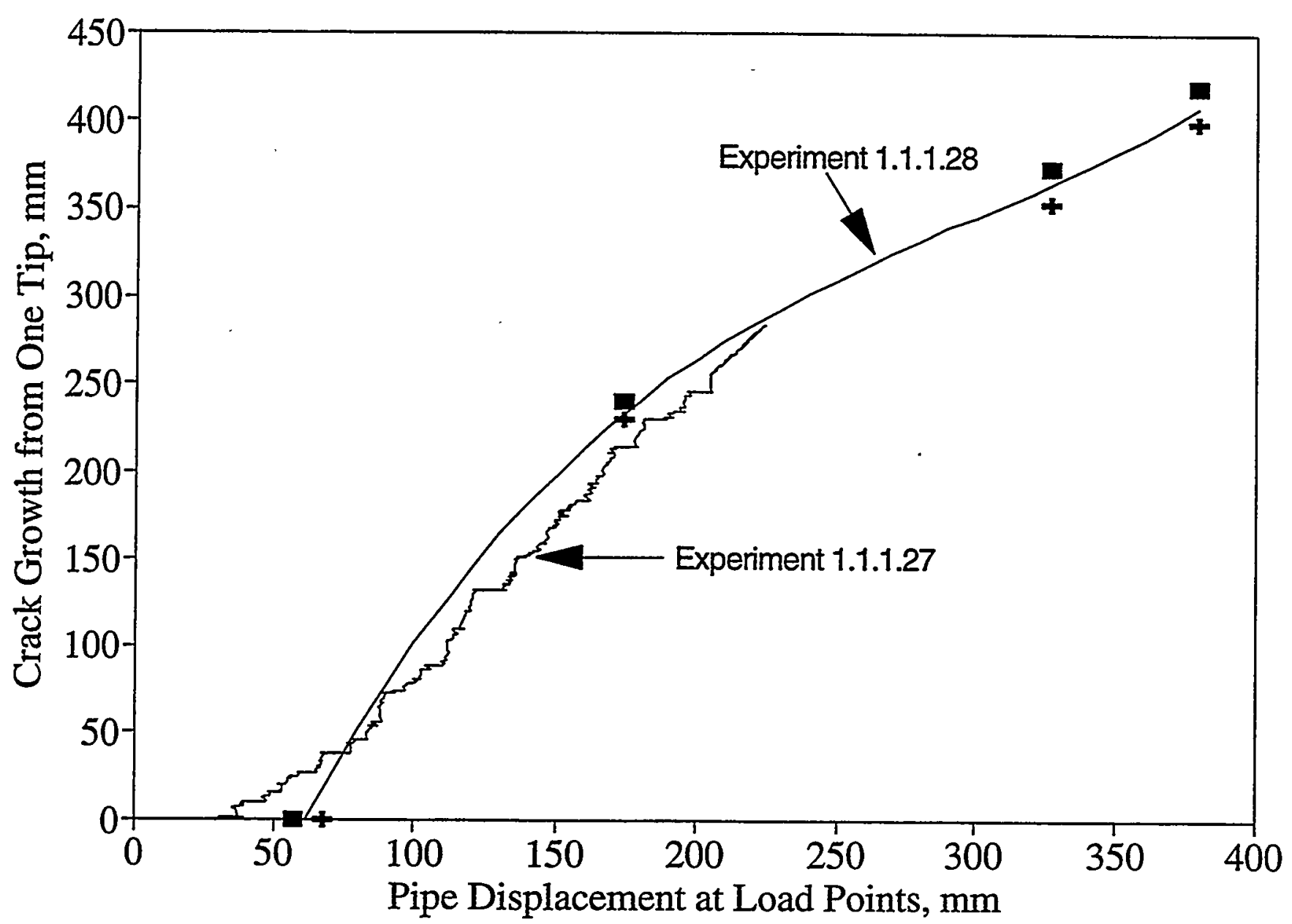

Figure 3.12 Comparison of crack growth as a function of pipe displacement at the load point for Experiments 1.1.1.27 and 1.1.1.28 
Figure 3.13 is a plot of the crack-mouth-opening displacement (CMOD) at each crack tip as a function of the projected crack growth at that crack tip. Figure 3.13a shows the data for Experiment 1.1.1.27, and Figure 3.13b shows the data for Experiment 1.1.1.28. The slope of the data shown in these figures is a function of the crack-tip-opening angle (CTOA), which is an indication of the fracture toughness. From Figure 3.13 it can be seen that the CTOA for Experiment 1.1.1.27 was approximately 50-percent higher than the CTOA for Experiment 1.1.1.28.

Figure 3.14 is a plot of the pipe ovalization (top-to-bottom and side-to-side) as a function of the pipe displacement at the load point for both experiments. Figure 3.14a shows the data for Experiment 1.1.1.27, and Figure 3.14b shows the data for Experiment 1.1.1.28. From Figure 3.14 it can be seen that the ovalization data for the two experiments are nearly identical. Both experiments ovalized in the typical fashion as experienced with other through-wall-cracked pipe experiments, i.e., increasing in diameter in the top-to-bottom direction and decreasing in diameter in the side-to-side direction, see Figure 3.14. The extent of the pipe ovalization for the two experiments was nearly the same for the same value of the pipe displacement at the load point. 


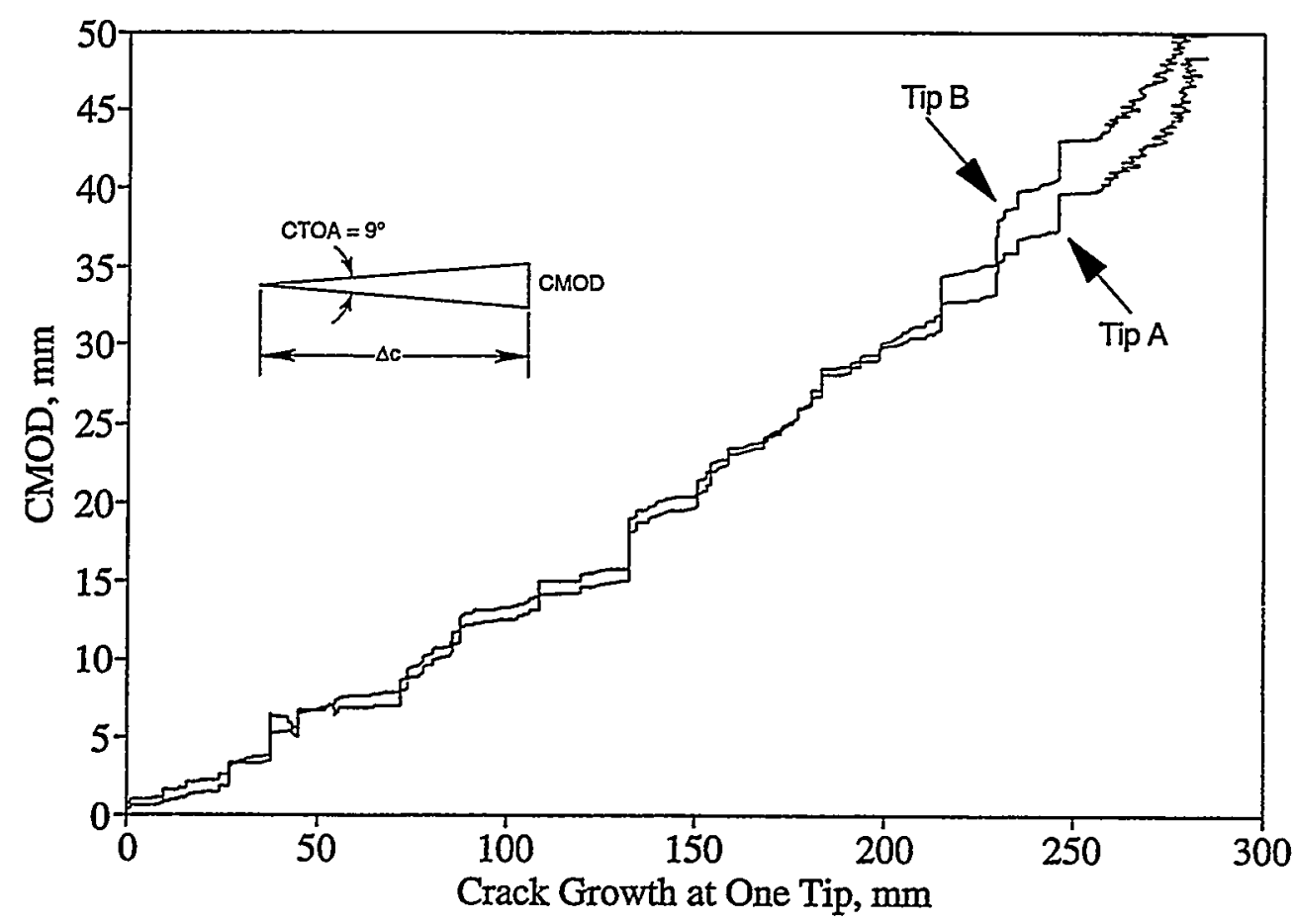

(a) Experiment 1.1.1.27

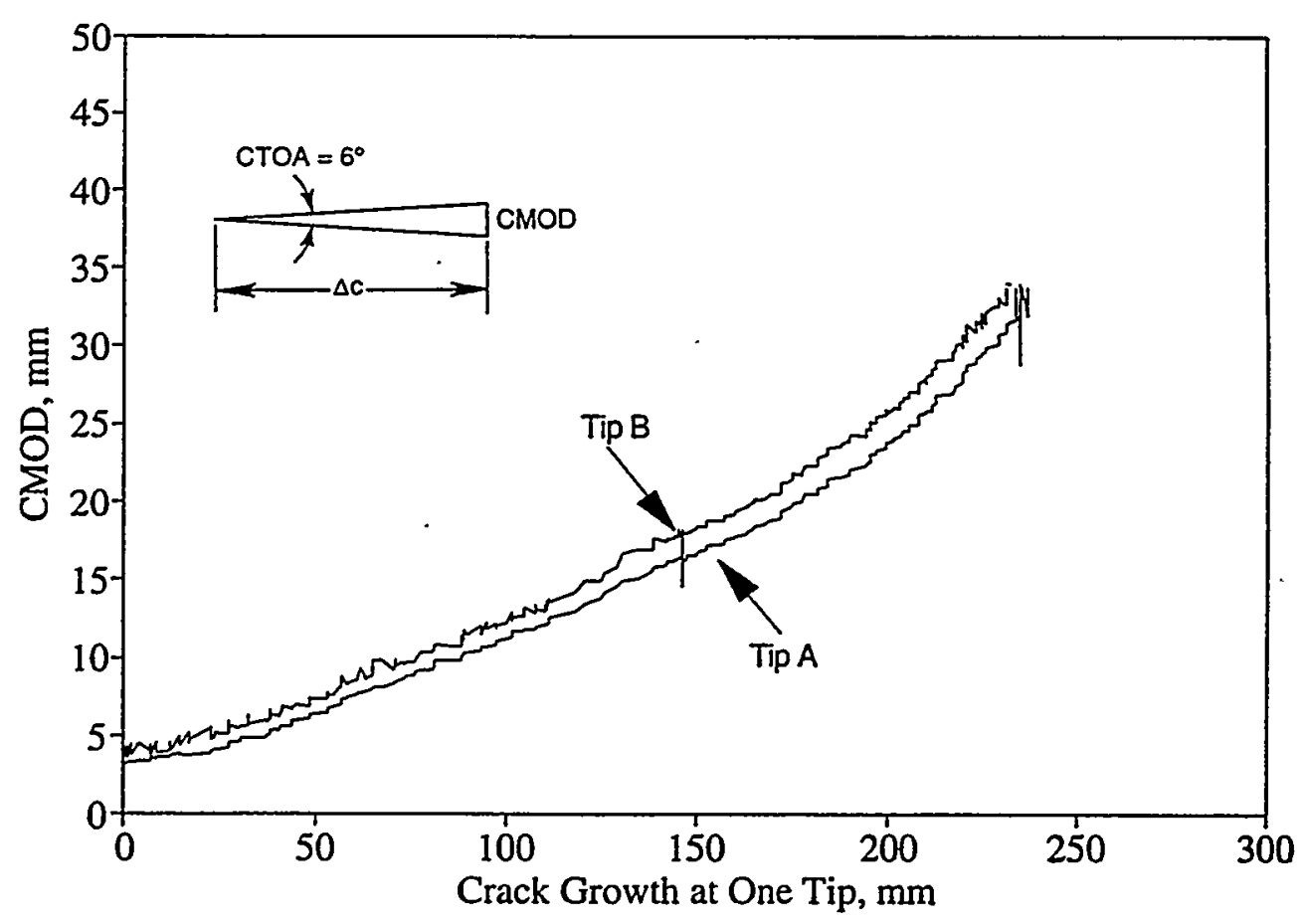

(b) Experiment 1.1.1.28

Figure 3.13 Crack tip CMOD as a function of crack growth 


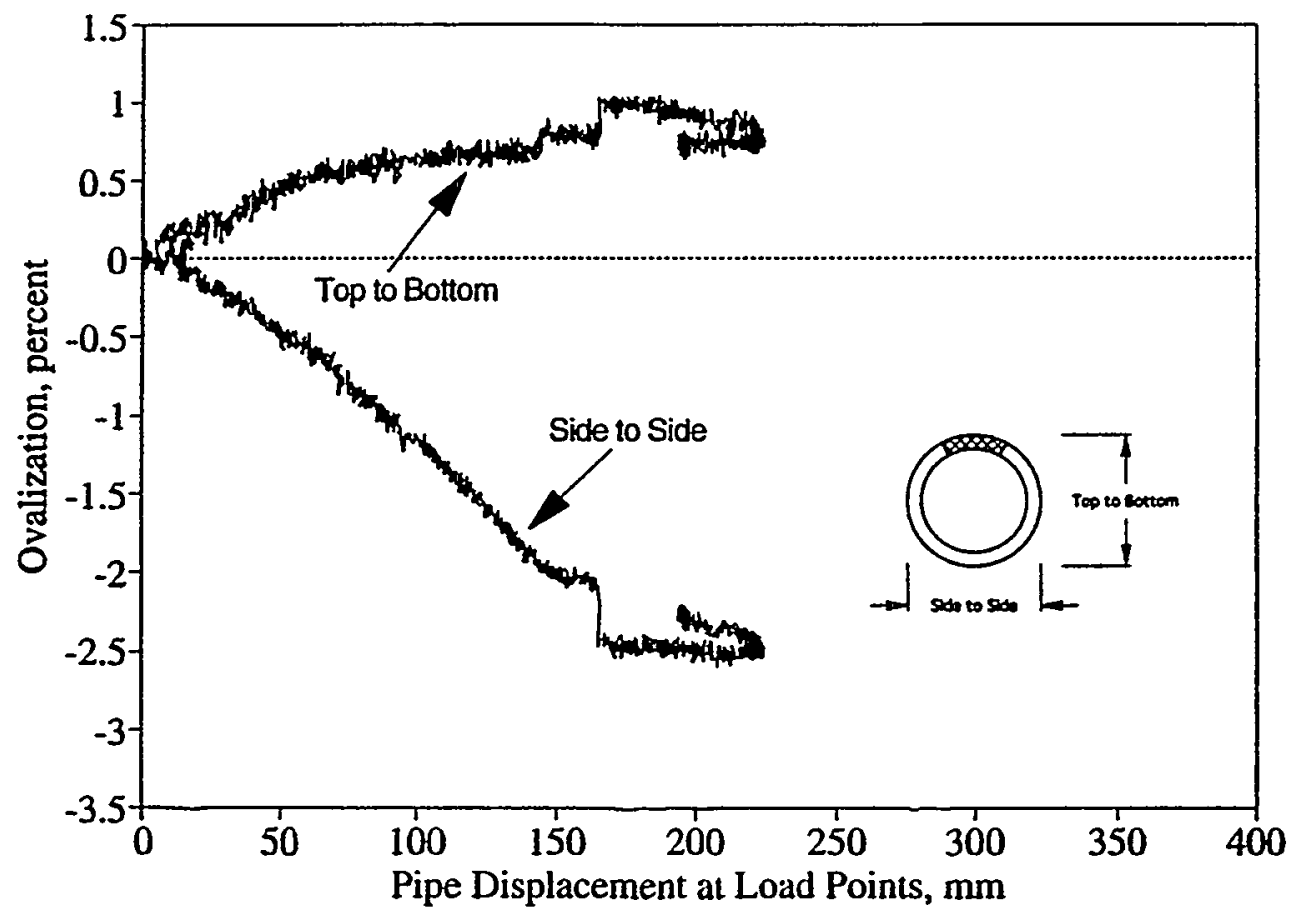

(a) Experiment 1.1.1.27

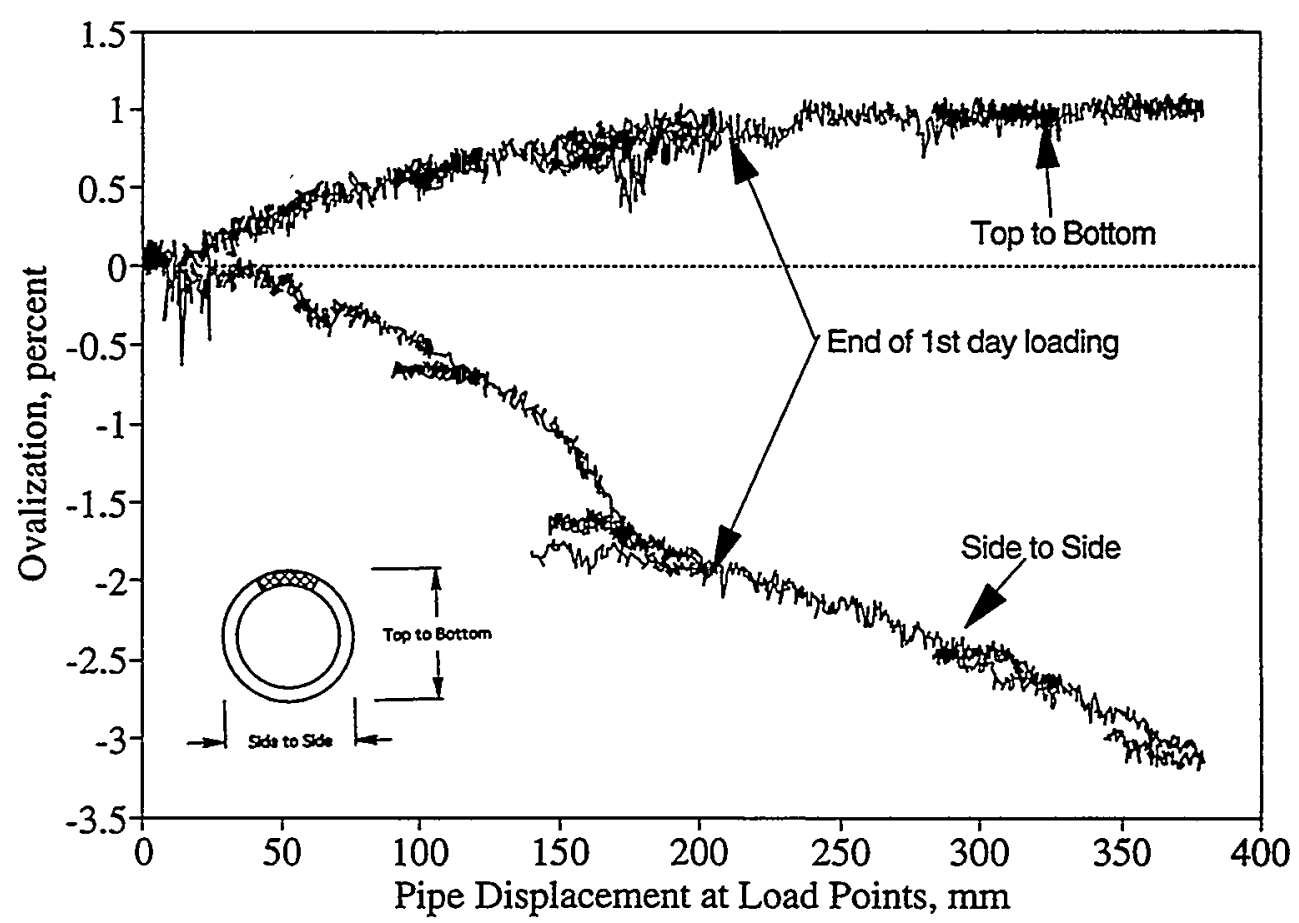

(b) Experiment 1.1.1.28

Figure 3.14 Ovalization of the pipe near the crack plane as a function of pipe displacement at the load point 


\subsection{References}

3.1 Wilkowski, G.M., and others, "Degraded Piping Program -- Phase II, Summary of Technical Results and Their Significance to Leak-Before-Break and In-Service Flaw Acceptance Criteria", March 1984-January 1989, NUREG/CR-4082, Volume 8, March, 1989. 


\section{ANALYSIS OF PIPE FRACTURE EXPERIMENT}

In this section of the report, the results of a limited series of analyses for Experiment 1.1.1.28 are presented. The analysis efforts consisted of (1) comparing the experimental crack initiation moments and maximum moments from Experiment 1.1.1.28 with predictions based on available fracture prediction models, and (2) calculating a J-R curve for this pipe experiment using the $\eta$-factor method and comparing this $\eta$-factor J-R curve with the $C(T)$ specimen J-R curves. Since there were no experimental load data, no analyses of Experiment 1.1.1.27 were made.

\subsection{Comparison of Results with Fracture Prediction Analyses}

The crack initiation moments and maximum moments from Experiment 1.1.1.28 were compared with predictions of crack initiation and maximum moments using a number of existing fracture prediction models. The experimental moments at crack initiation were compared with predictions from the

GE/EPRI method (Ref. 4.1),

LBB.ENG2 method (Ref. 4.2),

LBB.NRC method (Ref. 4.3),

LBB.GE method (Ref. 4.2),

Paris/Tada method (Ref. 4.4), and

R6 Revision 3 Option 1 method (Ref. 4.5).

In addition to the above methods, the experimental maximum moments were compared with maximum moment predictions based on the

Net-Section-Collapse (NSC) analysis (Refs. 4.6 and 4.7),

Dimensionless-Plastic-Zone-Parameter (DPZP) analysis (Ref. 4.8), and

ASME Section XI procedures (Refs. 4.9 and 4.10).

For each analysis method, predictions were made using the carbon steel pipe, stainless steel safe end, and Inconel weld metal tensile properties. In each case the flow stress was defined as the average of the actual yield and ultimate strengths. The fracture toughness properties (i.e., J-R curve) used in the analyses were based on the $C(T)$ specimen J-R curve for the fusion line region at the carbon steel pipe/Inconel 182 interface. For the five J-estimation schemes, i.e., GE/EPRI, LBB.ENG2, LBB.NRC, LBB.GE, and Paris/Tada, and the R6 method, the material stress-strain behavior was modeled using a Ramberg-Osgood relationship, where the equation was fit to the stress-strain data in 
the range from 0.1 percent strain to the strain corresponding to 80 percent of the ultimate strength. The fit of the stress-strain data to the Ramberg-Osgood equation was made using a Battelle-written computer program, ROFIT. Table 4.1 shows the quasi-static tensile properties (i.e., yield strength, ultimate strength, flow stress, modulus of elasticity (E), and Ramberg-Osgood coefficients) for the carbon steel pipe, stainless steel safe end, and Inconel weld metal used in these fracture prediction analyses. Figures 4.1 through 4.3 show the actual quasi-static tensile data for these materials, with the Ramberg-Osgood representation of the stress-strain data superimposed on the experimental stressstrain data.

Table 4.1 Tensile properties at $288 \mathrm{C}$ (550 F) of the A516 Grade 70 carbon steel pipe, F316 stainless steel safe end, and Inconel 182 SMAW weld metal used in the analyses of the bimetallic weld cold-leg pipe experiment

\begin{tabular}{ccccccccc}
\hline & $\begin{array}{c}\text { Yield } \\
\text { Strength, } \\
\text { MPa }\end{array}$ & $\begin{array}{c}\text { Ultimate } \\
\text { Tensile } \\
\text { Strength, } \\
\text { MPa }\end{array}$ & $\begin{array}{c}\text { Flow } \\
\text { Stress, } \\
\text { MPa }\end{array}$ & $\begin{array}{c}\text { Modulus } \\
\text { of } \\
\text { Elasticity, } \\
\text { GPa }\end{array}$ & $\begin{array}{c}\text { Reference } \\
\text { Stress, } \\
\mathbf{M P a}\end{array}$ & $\begin{array}{c}\text { Reference } \\
\text { Strain }\end{array}$ & $\boldsymbol{\alpha}$ & $\mathbf{n}$ \\
\hline A516 Grade 70 & 235 & 496 & 366 & 199.9 & 235 & 0.001174 & 2.07 & 5.20 \\
F316 Stainless & 157 & 415 & 286 & 178.3 & 157 & 0.0008817 & 9.89 & 3.67 \\
$\begin{array}{c}\text { Inconel 182 } \\
\text { SMAW }\end{array}$ & 372 & 599 & 486 & 178.3 & 372 & 0.002086 & 3.11 & 8.37 \\
\hline
\end{tabular}

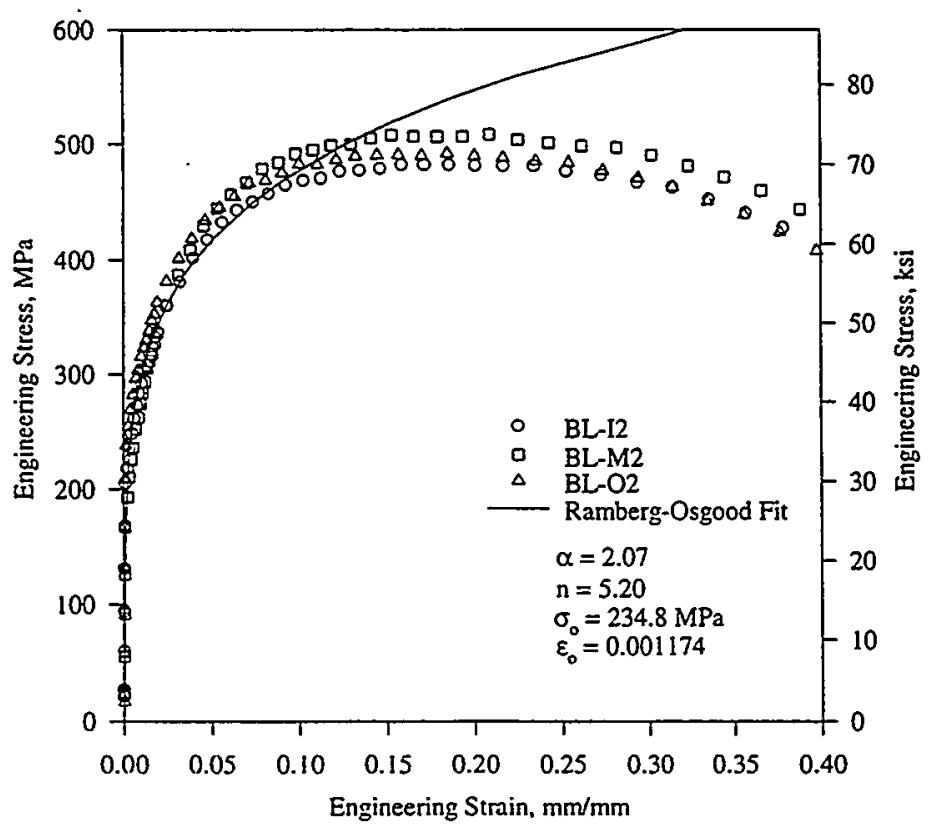

Figure 4.1 Quasi-static stress-strain data at 288 C (550 F) for A516 Grade 70 carbon steel pipe base material with Ramberg-Osgood representation of the stress-strain data superimposed 


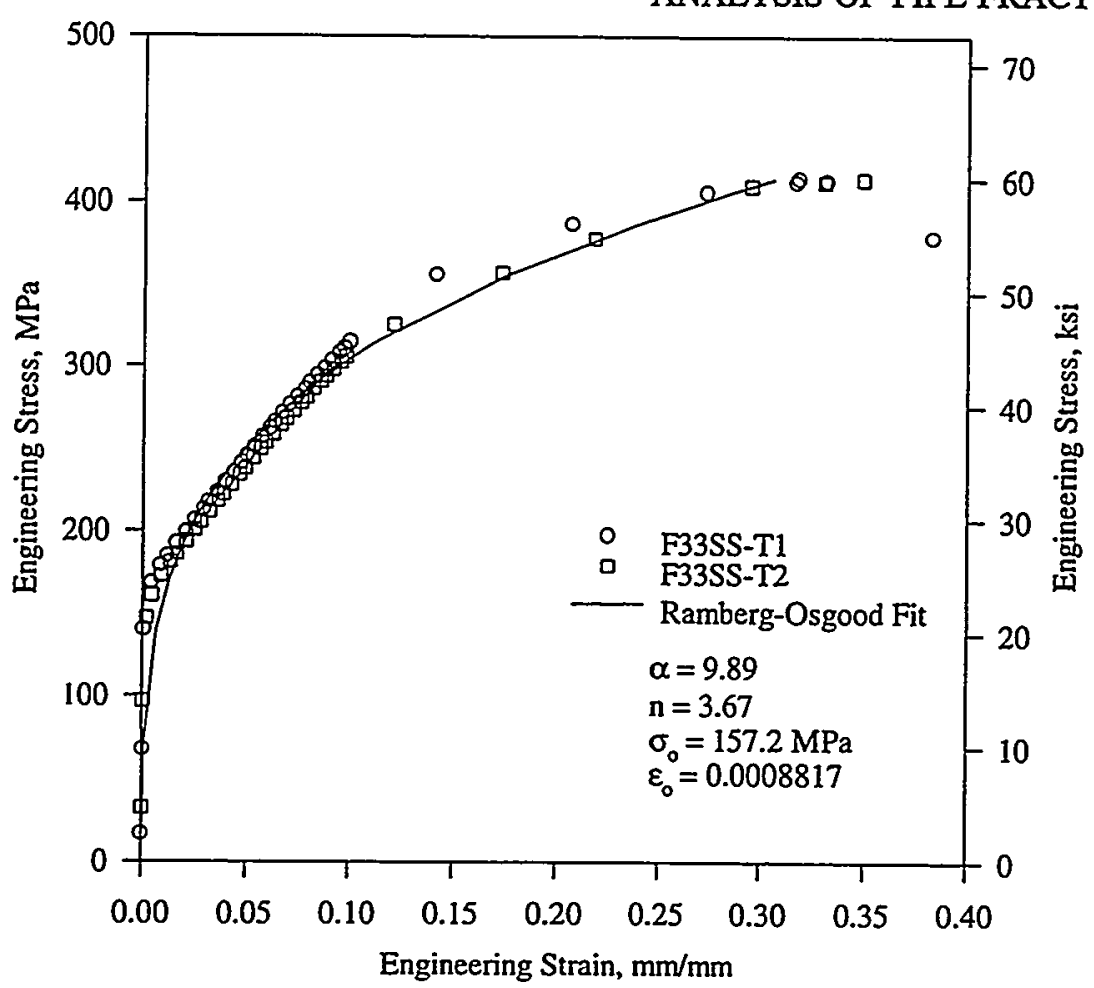

Figure 4.2 Quasi-static stress-strain data at $288 \mathrm{C} \mathrm{(550} \mathrm{F)} \mathrm{for} \mathrm{F316} \mathrm{stainless} \mathrm{steel} \mathrm{safe-end} \mathrm{base} \mathrm{material}$ with Ramberg-Osgood representation of the stress-strain data superimposed

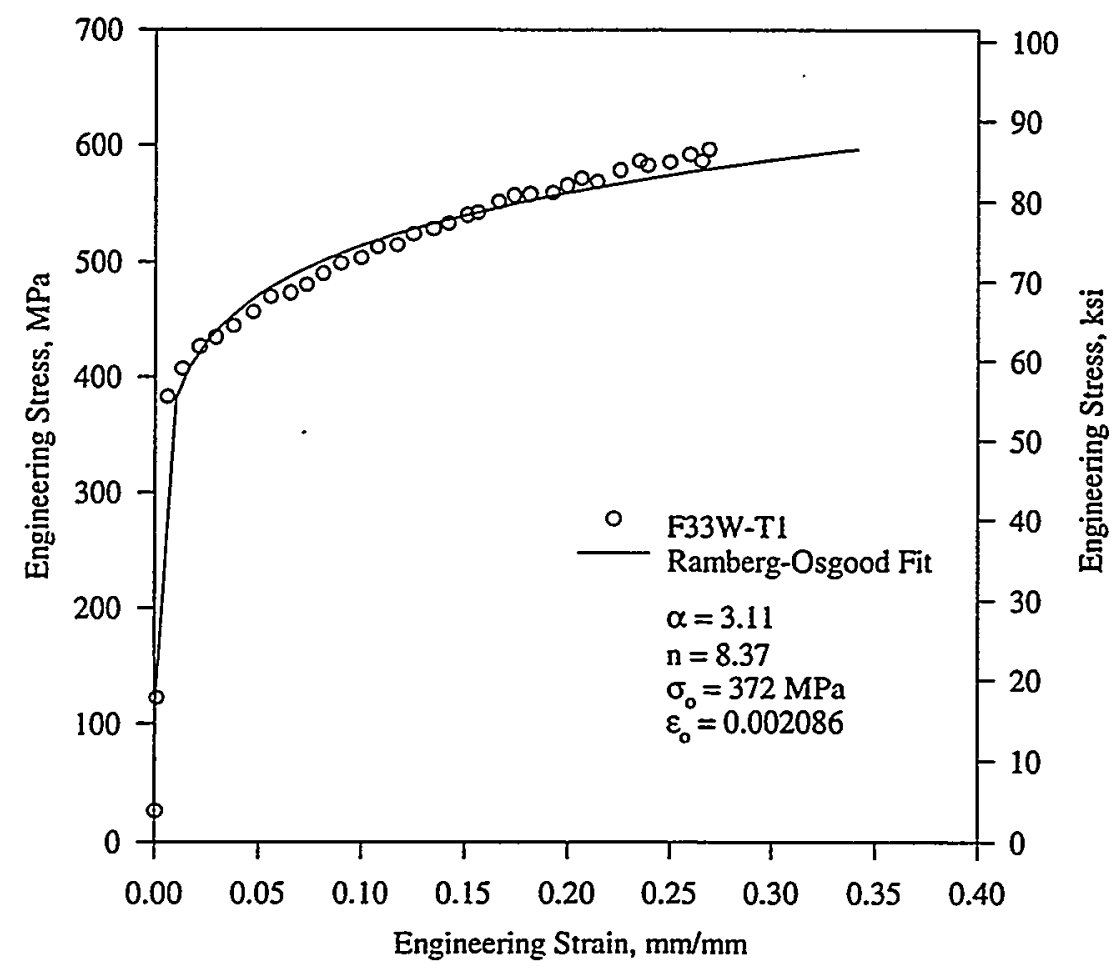

Figure 4.3 Quasi-static stress-strain data at $288 \mathrm{C}(550 \mathrm{~F})$ for Inconel 182 SMAW weld metal with Ramberg-Osgood representation of the stress-strain data superimposed 
The $J-R$ curve used in these analyses was based on Deformation theory $J$, i.e., $J_{D}-R$ curve, where the $\mathrm{J}_{\mathrm{D}}-\mathrm{R}$ curves were extrapolated using a power-law relationship in order to get the large amounts of crack growth needed for these analyses. Table 4.2 provides the extrapolated power-law $J_{D}-R$ curve constants. Figure 4.4 shows the extrapolated $J_{D}-R$ curve for the weld fusion line with the actual $C(T)$ specimen data superimposed.

Table 4.2 Extrapolated power-law $\mathrm{J}_{\mathrm{D}}-\mathrm{R}$ curve constants for quasi-static fusion-line data at $288 \mathrm{C}(550 \mathrm{~F})$ used in fracture analyses

\begin{tabular}{ccc}
\hline $\begin{array}{c}\text { Crack Growth } \\
\text { Region }\end{array}$ & $\begin{array}{c}\mathrm{C}_{\mathbf{1}}, \\
\mathrm{kJ} / \mathbf{m}^{2}\end{array}$ & $\mathbf{m}$ \\
\hline$\Delta \mathrm{a}=0^{(1)}$ & 684 & -- \\
$\Delta \mathrm{a}>0^{(2)}$ & 980 & 0.232 \\
\hline
\end{tabular}

(1) $\mathrm{J}=\mathrm{J}_{\mathrm{i}}=\mathrm{C}_{\mathrm{I}}$

(2) $\mathrm{J}=\mathrm{C}_{1}(\Delta \mathrm{a})^{\mathrm{m}}$

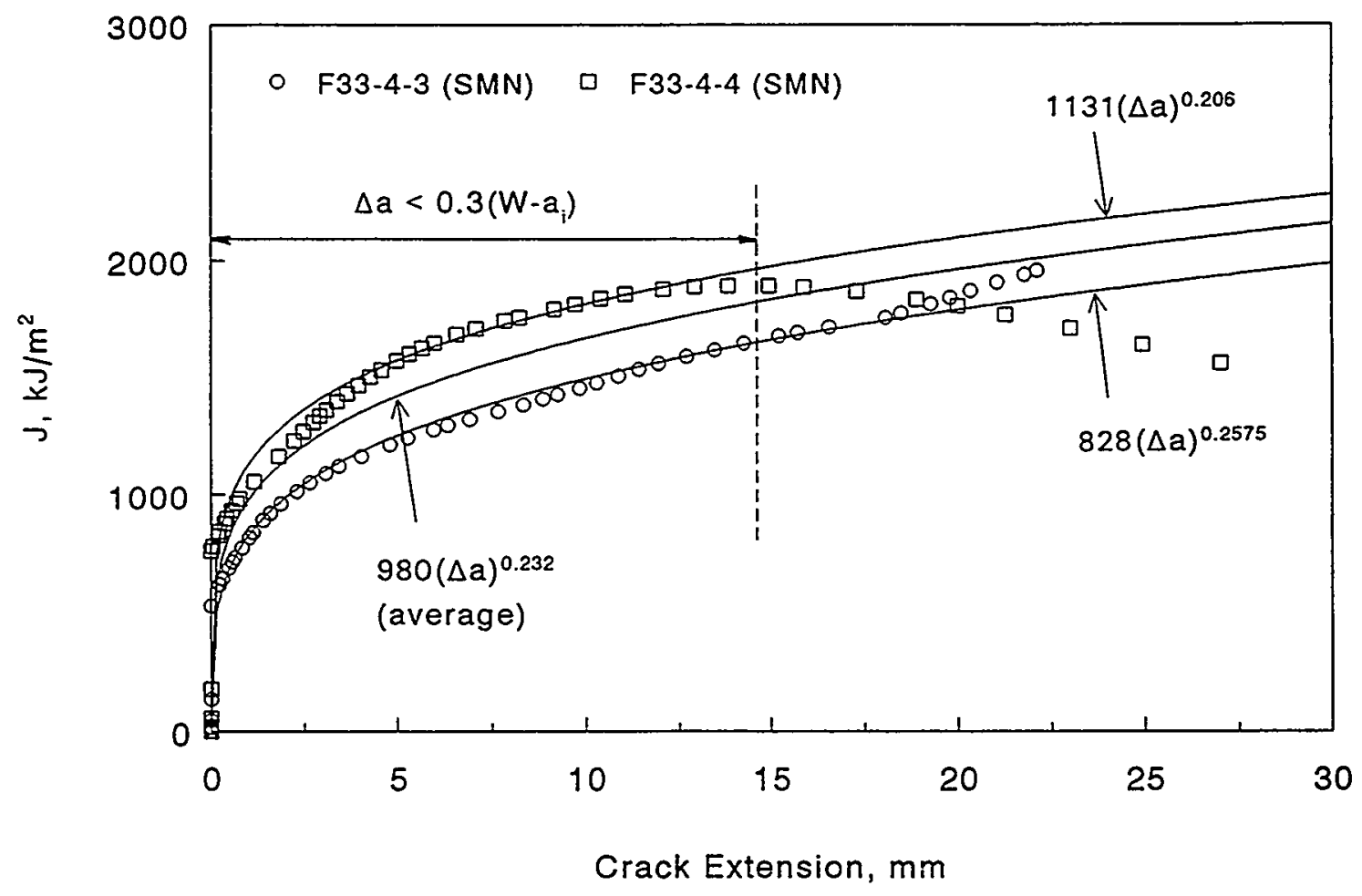

Figure 4.4 Extrapolated quasi-static $J_{\mathrm{D}}-\mathrm{R}$ curve at $288 \mathrm{C}(550 \mathrm{~F})$ for weld fusion-line with actual $\mathrm{C}(\mathrm{T})$ specimen data superimposed [Data considered valid for $\Delta \mathrm{a}<0.3\left(\mathrm{~W}-\mathrm{a}_{\mathrm{i}}\right)$.] 


\subsubsection{Comparison of the Experimental Moment at Crack Initiation with Fracture Analyses Predictions}

Comparisons were made between the experimental moment at crack initiation and the predicted crackinitiation moments using the GE/EPRI (Ref. 4.1), LBB.ENG2 (Ref. 4.2), LBB.NRC (Ref. 4.3), LBB.GE (Ref. 4.2), Paris/Tada (Ref. 4.4), and R6 Revision 3 Option 1 (Ref. 4.5) methods. Details of each of these methods can be found in the appropriate references. The pipe and crack dimensions used in the analyses are given in Table 4.3. The predictions were made with the aid of a Battellewritten computer code, NRCPIPE, Version 2.0(Test). (Note, the GE/EPRI method used in this analysis was the original GE/EPRI method with the plastic-zone correction.) The results of those comparisons are shown in Table 4.4 and Figure 4.5.

In examining Table 4.4 and Figure 4.5 , it can be seen that the use of the carbon steel pipe stressstrain curve results in a situation where the analysis methods consistently underpredicted the experimental moment at crack initiation, but the degree of underprediction was not excessive, i.e., less than 30 percent. This is in contrast to the cases where the stainless steel safe end or the Inconel weld metal stress-strain curves were used in the analyses. If the stainless steel safe-end-base-material stress-strain curve was used, then the analysis methods consistently underpredicted the experimental moments at crack initiation. The degree of underprediction was often excessive. In certain cases, e.g., when the GE/EPRI and LBB.ENG2 analysis methods were used, the predicted moments at crack initiation were about only half of the experimental moment at crack initiation. On the other hand, if the Inconel weld metal stress-strain curve was used in the analysis, the agreement between the predictions and the experiment was much better, but the predictions were not always less than the experimental values, i.e., in certain cases the analyses overpredicted the experimental moment at crack initiation.

Table 4.3 Pipe and crack dimensions used in fracture analyses of Experiment 1.1.1.28

\begin{tabular}{ccc}
\hline $\begin{array}{c}\text { Outside Diameter, } \\
\mathbf{m m} \text { (inch) }\end{array}$ & $\begin{array}{c}\text { Wall Thickmess, } \\
\text { mm (inch) }\end{array}$ & $\mathbf{2 c / \pi D}$ \\
\hline $930(36.6)$ & $81.3(3.2)$ & 0.359 \\
\hline
\end{tabular}


Table 4.4 Comparison of the experimental moment at crack initiation for Experiment 1.1.1.28 with the fracture analyses predictions of the crack initiation moments (using fusion-line C(T) specimen J-R curve data)

\begin{tabular}{|c|c|c|c|c|c|c|}
\hline \multirow[b]{2}{*}{$\begin{array}{l}\text { Predictive } \\
\text { Method }\end{array}$} & \multicolumn{3}{|c|}{$\begin{array}{l}\text { Predicted Crack Initiation Moment }{ }^{(a)}, M N-m \\
\text { (Using Tensile Properties of) }\end{array}$} & \multicolumn{3}{|c|}{$\begin{array}{l}\text { Experimental }{ }^{(\mathrm{b})} / \text { Predicted } \\
\text { Crack Initiation Moment } \\
\text { (Using Tensile Properties of }\end{array}$} \\
\hline & $\begin{array}{l}\text { Carbon Steel } \\
\text { Pipe }\end{array}$ & $\begin{array}{l}\text { Stainless } \\
\text { Steel } \\
\text { Safe End }\end{array}$ & Inconel Weld & $\begin{array}{l}\text { Carbon Steel } \\
\text { Pipe }\end{array}$ & $\begin{array}{l}\text { Stainless } \\
\text { Steel } \\
\text { Safe End }\end{array}$ & $\begin{array}{l}\text { Inconel } \\
\text { Weld }\end{array}$ \\
\hline GE/EPRI & 5.30 & 3.13 & 6.51 & 1.276 & 2.164 & 1.039 \\
\hline LBB.ENG2 & 5.89 & 3.42 & 7.41 & 1.149 & 1.978 & 0.914 \\
\hline LBB.NRC & 6.70 & 4.34 & 7.39 & 1.011 & 1.558 & 0.916 \\
\hline LBB.GE & 6.09 & 3.72 & 7.35 & 1.111 & 1.818 & 0.921 \\
\hline PARIS/TADA & 6.52 & 5.85 & 6.44 & 1.039 & 1.157 & 1.051 \\
\hline R6 & 5.24 & 3.86 & 6.66 & 1.293 & 1.756 & 1.016 \\
\hline
\end{tabular}

(a) Using fusion line $\mathrm{C}(\mathrm{T})$ specimen $\mathrm{J}_{\mathrm{D}}-\mathrm{R}$ curve

(b) Experimental moment at crack initiation $=6.77 \mathrm{MN}-\mathrm{m}$

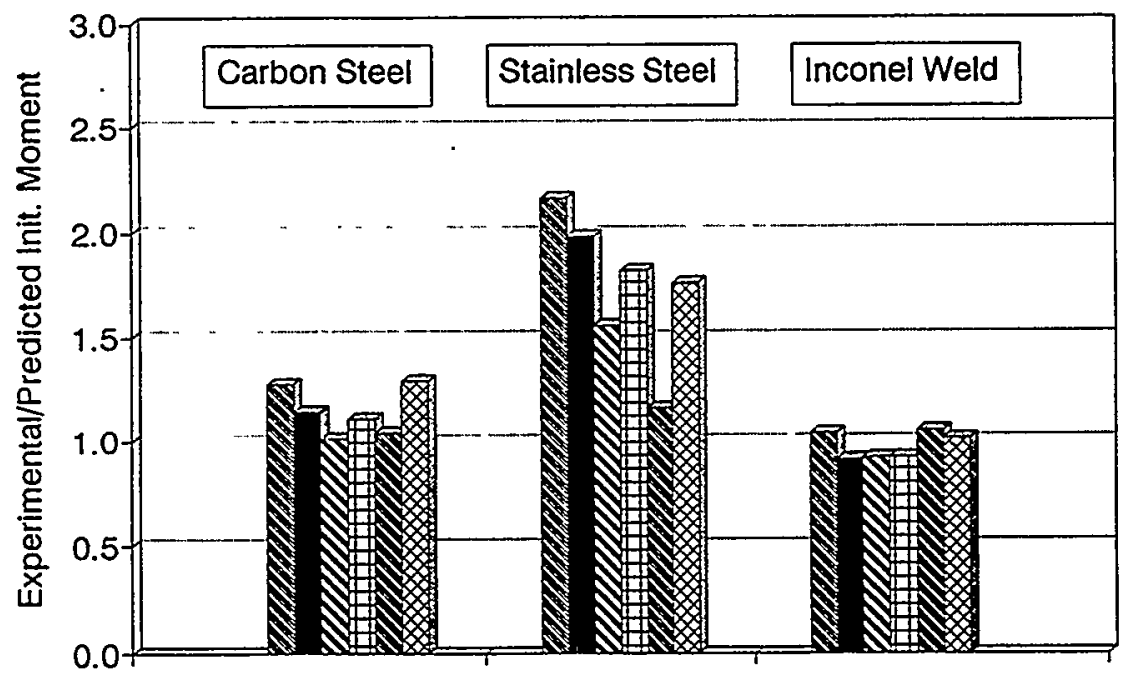

\begin{tabular}{|ll}
\hline LE/EPRI & LBB.ENG2 LBB.NRC \\
LB.GE & RARIS
\end{tabular}

Figure 4.5 Comparison of experimental moment at crack initiation with predicted moments at crack initiation for Experiment 1.1.1.28 using three different stress-strain curves in the analyses and six different analysis methods (using fusion-line $C(T)$ specimen $J-R$ curve data) 


\subsubsection{Comparison of the Maximum Experimental Moment with Fracture Analyses Predictions}

Comparisons were made between the maximum experimental moment for Experiment 1.1.1.28 and the predicted maximum moments using the Net-Section-Collapse (Refs. 4.6 and 4.7), DimensionlessPlastic-Zone-Parameter (Ref. 4.8), GE/EPRI (Ref. 4.1), LBB.ENG2 (Ref. 4.2), LBB.NRC (Ref. 4.3), LBB.GE (Ref. 4.2), Paris/Tada (Ref. 4.4), R6 Revision 3 Option 1 (Ref. 4.5), and the ASME Section XI criteria for ferritic and austenitic piping (Refs. 4.9 and 4.10). Details of each of these analysis methods can be found in the appropriate references. (The ASME Section XI criteria were those found in Appendix $\mathrm{C}$ for austenitic piping and Appendix $\mathrm{H}$ for ferritic piping, with the appropriate Z-factor for a shielded-metal-arc weld [SMAW].) The predictions were made with the aid of a Battelle-written computer code, NRCPIPE, Version 2.0(Test). (Note, the GE/EPRI method used in this analysis was the original GE/EPRI method, with the plastic-zone correction.) The fusion line $C(T)$ specimen $J_{D}-R$ curve was used in all analyses. The results of these comparisons are shown in Table 4.5 and Figures 4.6 through 4.8. Figure 4.6 is for the case where the carbon steel pipe stress-strain curve is used, Figure 4.7 is for the case where the stainless steel safe end stress-strain curve is used, and Figure 4.8 is for the case where the Inconel weld stress-strain curve is used.

In examining Table 4.5 and Figures 4.6 through 4.8 , it can be seen that the use of the stainless steel, safe-end, stress-strain curve results in a consistent underprediction of the maximum experimental moments. The degree of the underprediction is oftentimes excessive. It can also be seen that the use of the Inconel weld stress-strain curve in the analyses tends to result in a consistent overprediction of the maximum experimental moments. The exceptions to this finding are the predictions using the DPZP and the ASME Section XI Appendix C analysis methods. The fact that the ASME analysis results in an underprediction of the experimental moments is not that surprising in that this analysis method is more of a fracture prevention analysis, with built-in safety factors, instead of a true fracture prediction analysis. (Note, the applied safety factors for the ASME analysis were assumed to be 1.0 for this comparative analysis.)

Finally, in reviewing Table 4.5 and Figures 4.6 through 4.8, it can be seen that the use of the carbon steel pipe stress-strain curve results in the most consistent prediction of the maximum experimental moments. When the carbon steel pipe stress-strain curve was used in the analyses, there were instances where the analyses overpredicted the maximum experimental moments, but the degree of overprediction was not that significant. Note, the fact that the Net-Section-Collapse analysis overpredicted the experimental results is not that surprising for this large diameter pipe since fully plastic conditions were probably not satisfied for this size pipe. 
Table 4.5 Comparison of the maximum experimental moment for Experiment 1.1.1.28 with the fracture analyses predictions of the maximum moment

\begin{tabular}{|c|c|c|c|c|c|c|}
\hline \multirow[b]{2}{*}{$\begin{array}{l}\text { Predictive } \\
\text { Method }\end{array}$} & \multicolumn{3}{|c|}{$\begin{array}{l}\text { Predicted Maximum Moment } t^{(\mathrm{a})}, \mathrm{MN}-\mathrm{m} \\
\text { (Using Tensile Properties of) }\end{array}$} & \multicolumn{3}{|c|}{$\begin{array}{l}\begin{array}{l}\text { Experimental } \\
\text { Moment } \\
\text { Moredicted }\end{array} \\
\text { (Using Tensile Properties of) }\end{array}$} \\
\hline & $\begin{array}{l}\text { Carbon Steel } \\
\text { Pipe }\end{array}$ & $\begin{array}{l}\text { Stainless } \\
\text { Steel } \\
\text { Safe End }\end{array}$ & Inconel Weld & $\begin{array}{l}\text { Carbon Steel } \\
\text { Pipe }\end{array}$ & $\begin{array}{l}\text { Stainless } \\
\text { Steel } \\
\text { Safe End }\end{array}$ & $\begin{array}{c}\text { Inconel } \\
\text { Weld }\end{array}$ \\
\hline GE/EPRI & 6.37 & 3.81 & 7.96 & 1.092 & 1.826 & 0.874 \\
\hline LBB.ENG2 & 6.96 & 4.11 & 8.92 & 0.999 & 1.690 & 0.780 \\
\hline LBB.NRC & 7.92 & 5.23 & 9.84 & 0.878 & 1.331 & 0.707 \\
\hline LBB.GE & 7.25 & 4.50 & 8.75 & 0.960 & 1.546 & 0.794 \\
\hline PARIS/TADA & 8.17 & 6.53 & 9.33 & 0.852 & 1.065 & 0.745 \\
\hline R6 & 5.73 & 4.15 & 7.89 & 1.213 & 1.677 & 0.881 \\
\hline NSC & 8.41 & 6.58 & 11.18 & 0.827 & 1.056 & 0.622 \\
\hline DPZP & 6.46 & 5.65 & 6.67 & 1.076 & 1.231 & 1.043 \\
\hline ASME & $3.47^{(c)}$ & - & $4.71^{(\mathrm{d})}$ & $2.006^{(c)}$ & - & $1.475^{(\mathrm{d})}$ \\
\hline
\end{tabular}

(a) Using fusion line $C(T)$ specimen $J_{D}-R$ curve.

(b) Maximum experimental moment $=6.95 \mathrm{MN}-\mathrm{m}$.

(c) Using Appendix $\mathrm{H}$ with safety factor of 1.0.

(d) Using Appendix C with safety factor of 1.0.

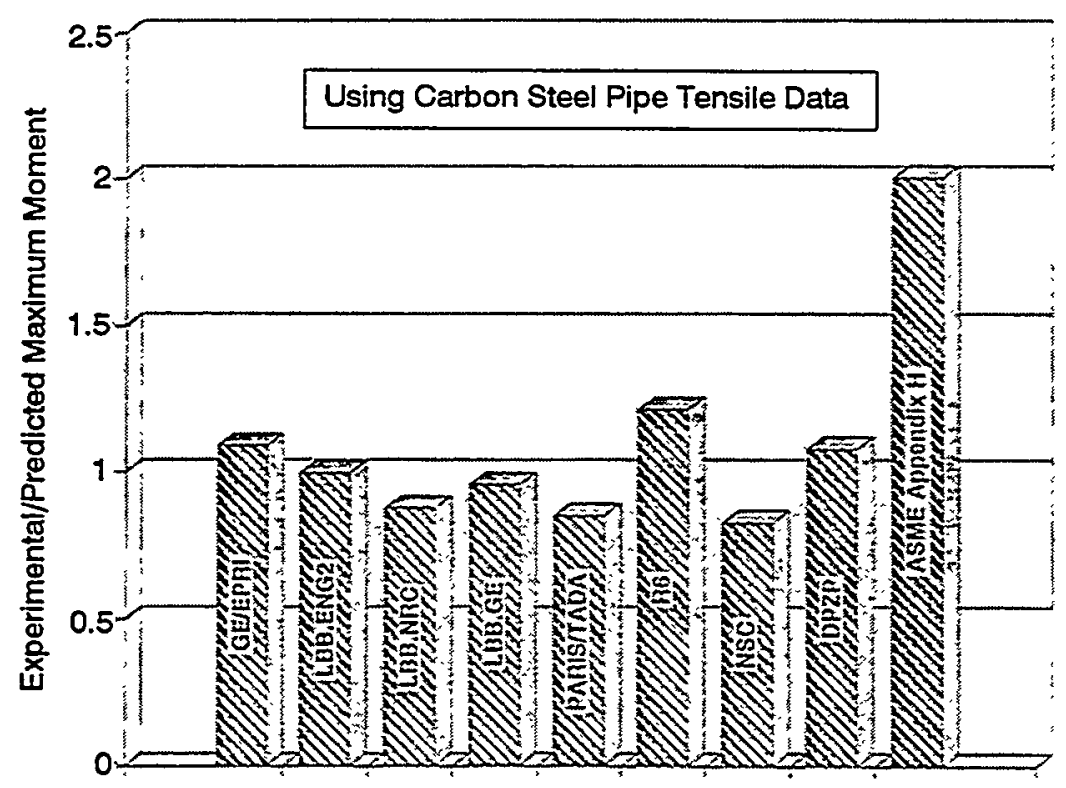

Figure 4.6 Comparison of maximum experimental moment with maximum predicted moments for Experiment 1.1.1.28 using the fusion-line $C(T)$ specimen $J_{D}-R$ curve with the carbon steel pipe stress-strain curve and nine different analysis methods 


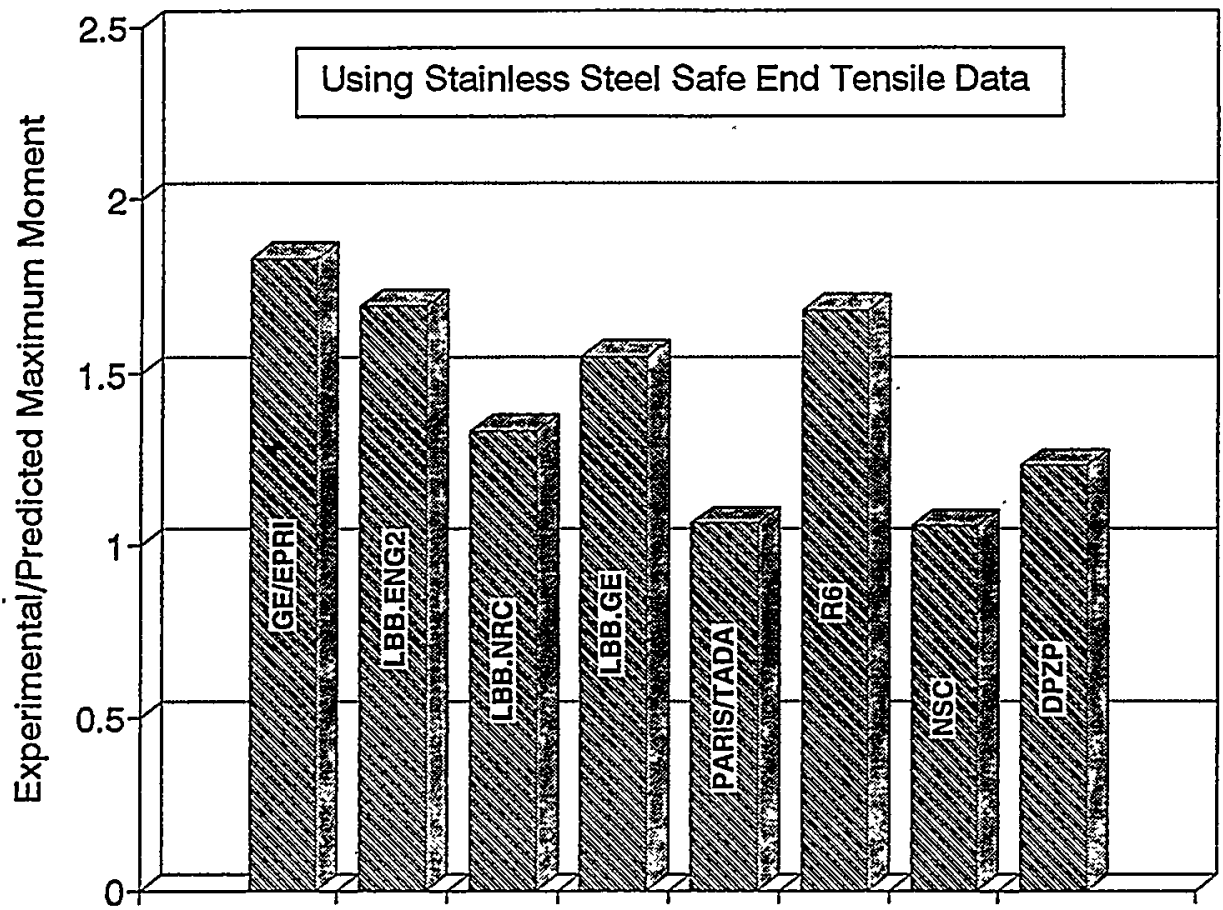

Figure 4.7 Comparison of maximum experimental moment with maximum predicted moments for Experiment 1.1.1.28 using the fusion line $C(T)$ specimen $J_{D}-R$ curve with the stainless steel safe-end stress-strain curve and nine different analysis methods

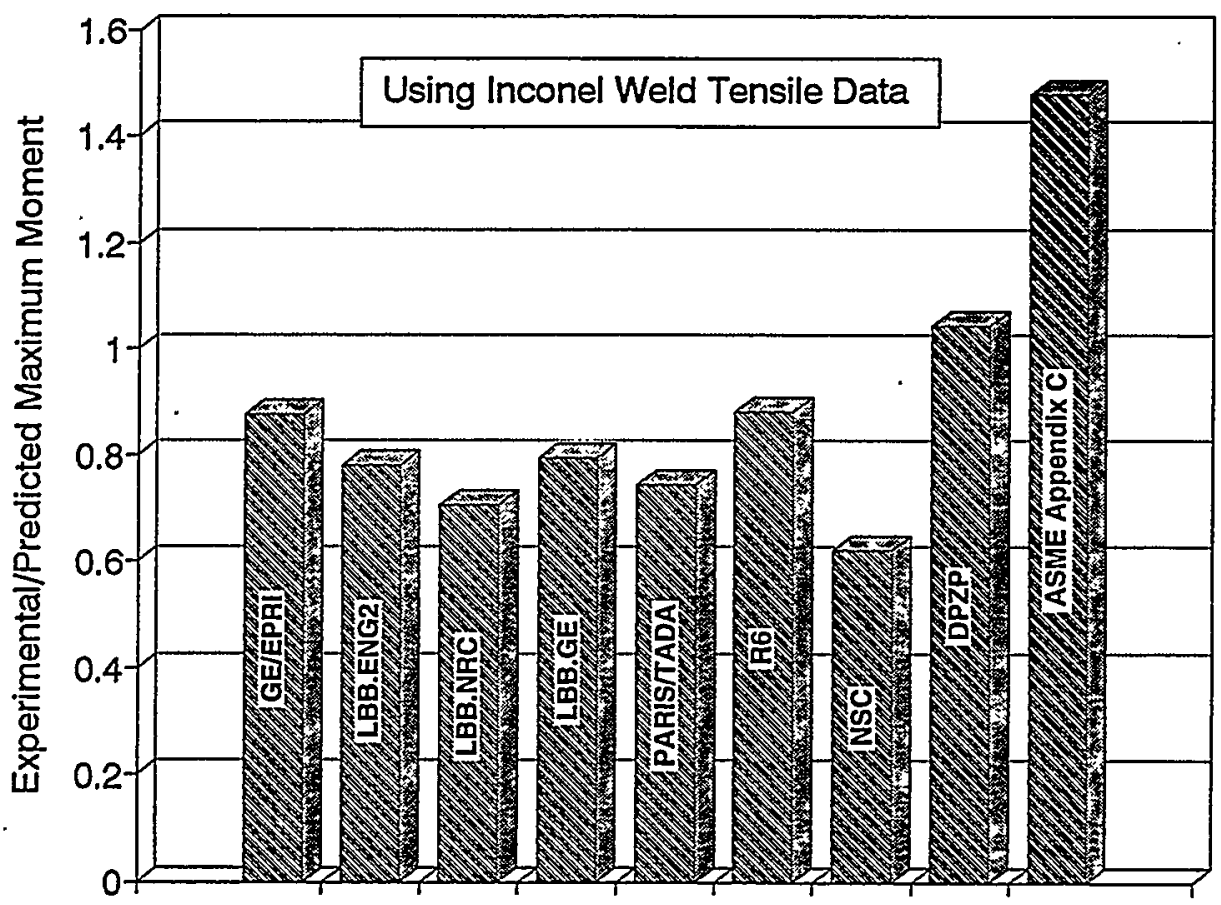

Figure 4.8 Comparison of maximum experimental moment with maximum predicted moments for Experiment 1.1.1.28 using the fusion-line $C(T)$ specimen $J_{D}-R$ curve with the Inconel 182 weld stress-strain curve and nine different analysis methods 


\subsubsection{Comparison of the Predicted and Experimental Moment-Rotation Curves for Experiment 1.1.1.28}

For the five J-estimation schemes used in this analysis (i.e., GE/EPRI, LBB.ENG2, LBB.NRC, LBB.GE, and Paris/Tada), it was possible to predict the full moment-rotation curve for the experiment and compare these curves with the experimental moment-rotation curve for Experiment 1.1.1.28. As was the case for the crack-initiation and maximum-moment predictions, the predictions of the moment-rotation curves were made using the stress-strain curves for the carbon steel pipe, stainless steel safe end, and the Inconel weld. In each case, the power-law extrapolated fusion-line $\mathrm{J}_{\mathrm{D}}-\mathrm{R}$ curve was used in the analysis. The results of those predictions are shown in Figures 4.9 through 4.11. In each figure, the experimental moment-rotation curve is shown for comparison purposes. Figure 4.9 is for the case where the carbon steel pipe stress-strain was used in the analysis. Figure 4.10 is for the case where the stainless steel safe-end stress-strain curve was used. Figure 4.11 is for the case where the Inconel weld stress-strain curve was used.

An examination of Figures 4.9 through 4.11 shows that each of the analysis methods for all of the stress-strain curves was suitable for predicting the rotations at maximum moment. As noted previously, the value of the predicted maximum moment varied significantly depending on the stressstrain curve and analysis method used, but the rotations at maximum moment were fairly consistent with each other and the experimental value. The biggest discrepancy with the predictions evident in Figures 4.9 through 4.11 is the fact that all of the analyses tended to significantly underpredict the experimental moments for a given rotation after maximum moment was reached, regardless of which stress-strain curve was used in the analyses. Similar results have been observed in the past where the $\mathrm{J}_{\mathrm{D}}-\mathrm{R}$ curve was used in the analyses. $\mathrm{J}_{\mathrm{M}}-\mathrm{R}$ curve predictions usually are more accurate in this large crack growth regime. Figure 4.12 is a plot of the predictions and experimental moment-rotation curves using the tensile properties of the $A 516$ Grade 70 carbon steel pipe material and the $J_{M}-R$ curve for the fusion line. Comparison of Figure 4.12 with Figure 4.9 shows that using the $J_{M}-R$ curve results in more accurate predictions of the full moment-rotation response of the cracked pipe than when using the $\mathrm{J}_{\mathrm{D}}-\mathrm{R}$ curve. 


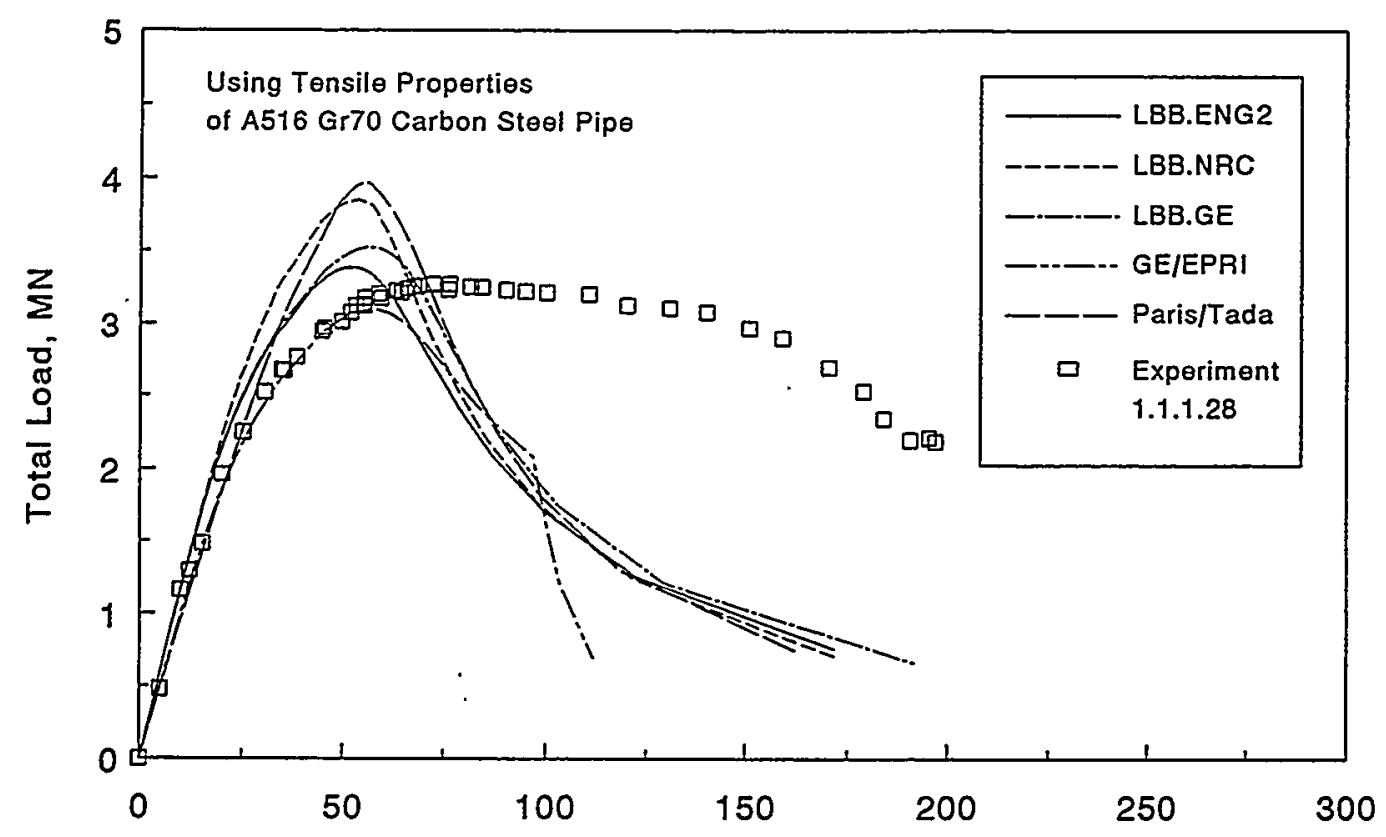

Pipe Displacement at Load Point, mm

Figure 4.9 Comparison of the experimental moment-rotation curve with the predicted moment-rotation curves from five analysis methods using the A516 Grade 70 carbon steel pipe stress-strain data

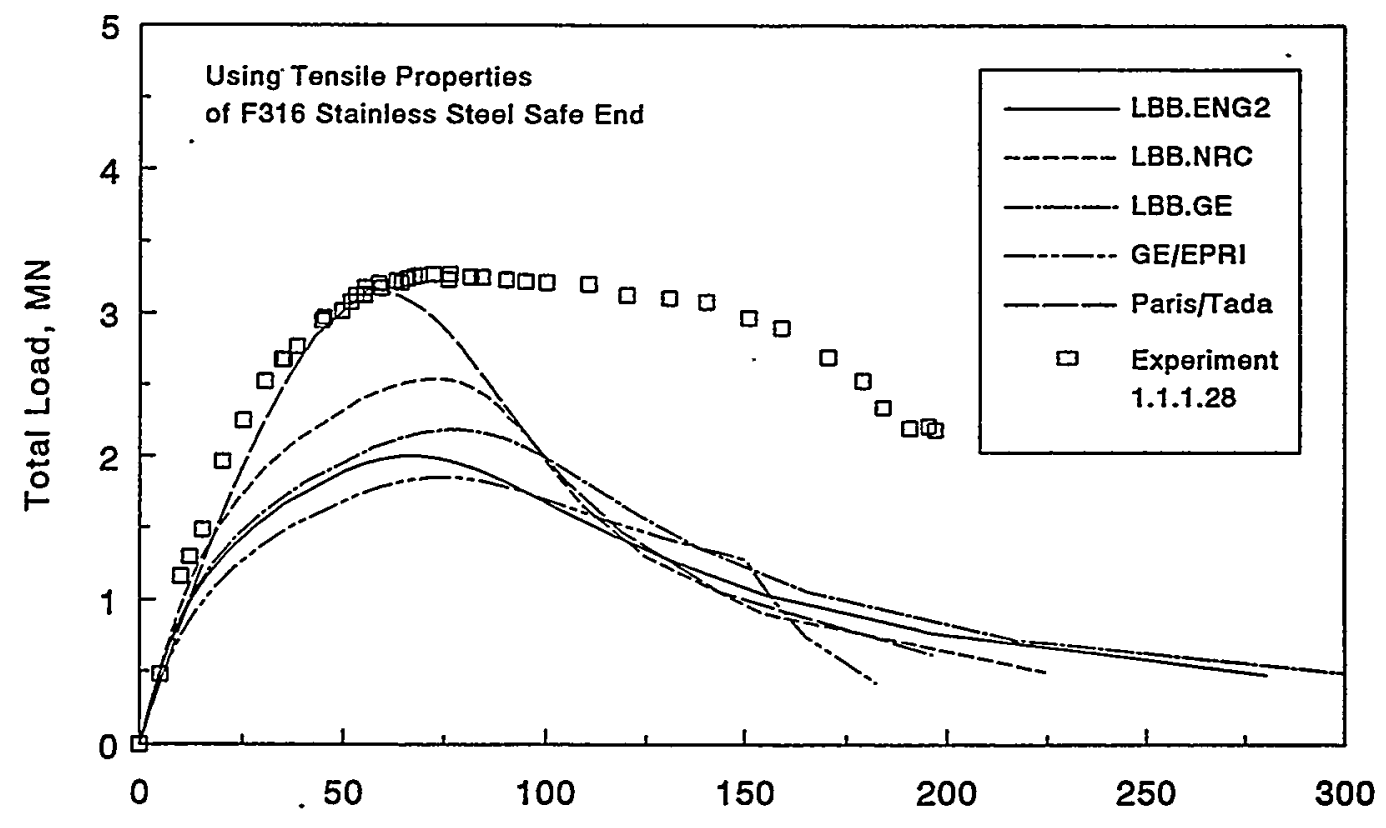

Pipe Displacement at Load Point, $\mathrm{mm}$

Figure 4.10 Comparison of the experimental moment-rotation curve with the predicted moment-rotation curves from five analysis methods using the $\mathrm{F316}$ stainless steel safe-end stress-strain data 


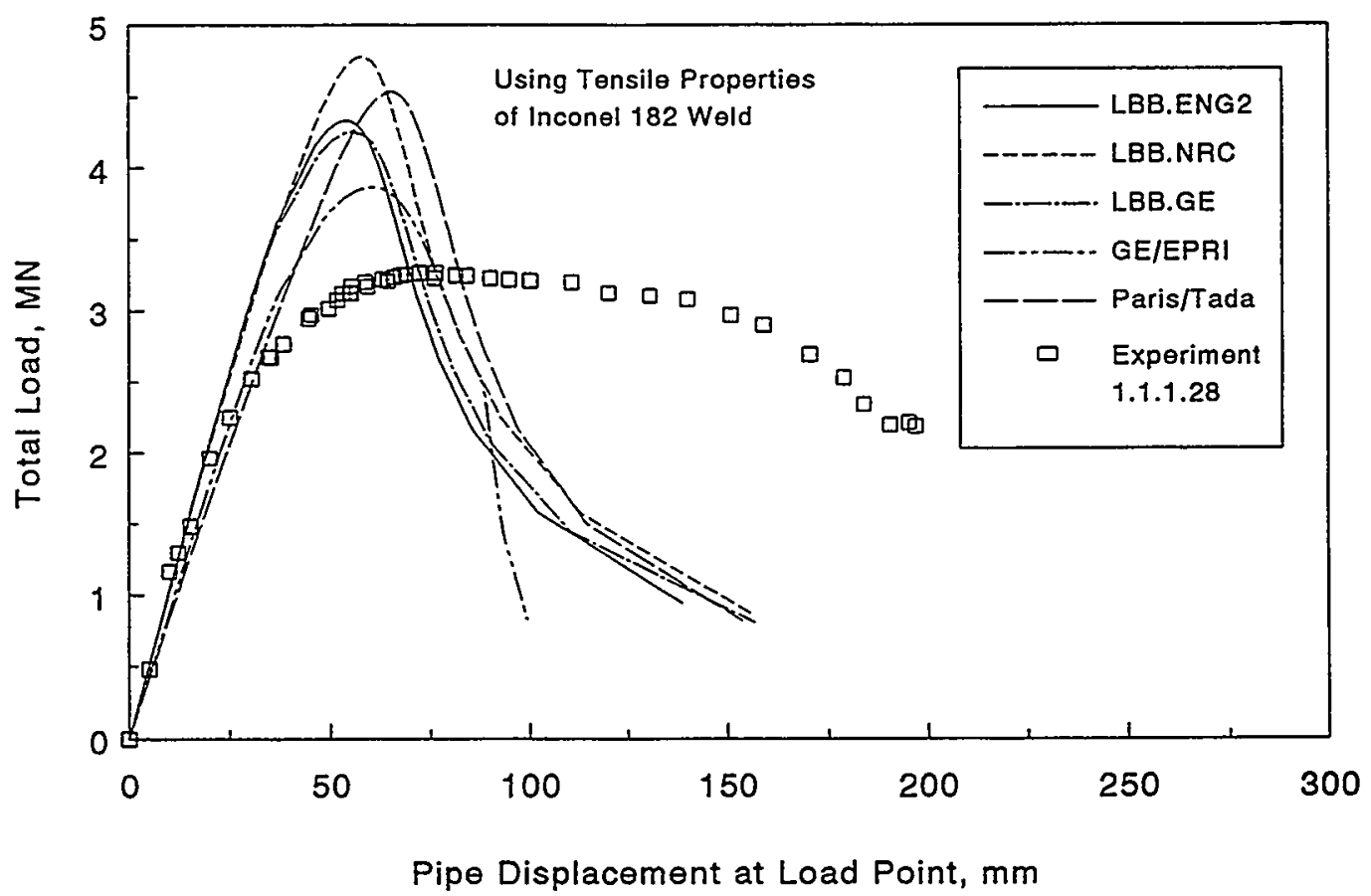

Figure 4.11 Comparison of the experimental moment-rotation curve with the predicted moment-rotation curves from five analysis methods using the Inconel 182 weld stress-strain data

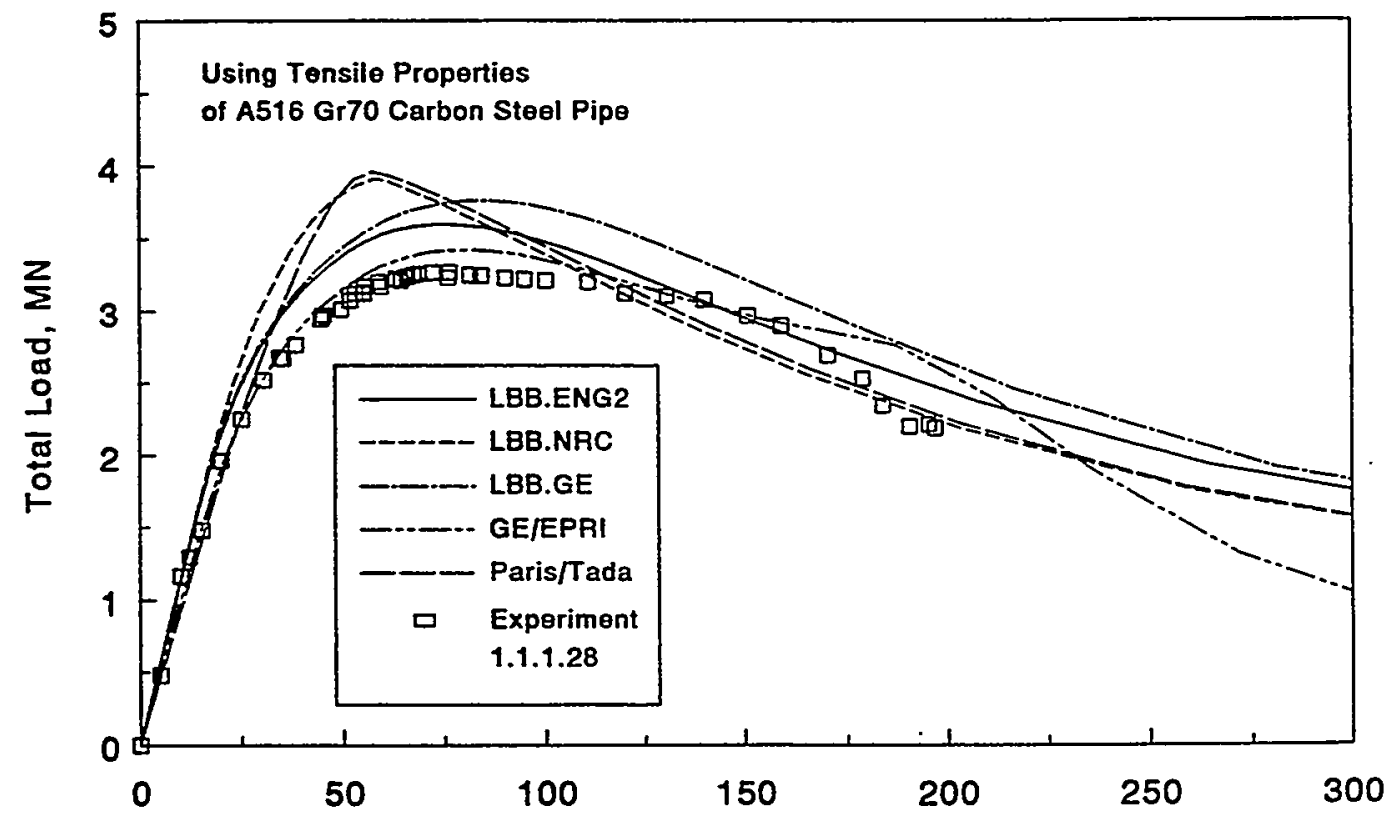

Pipe Displacement at Load Point, mm

Figure 4.12 Comparison of the experimental moment-rotation curve with the predicted momentrotation curves from five analysis methods using the A516 Grade 70 carbon steel pipe stress-strain data and the $J_{M}-R$ curve for the fusion line 


\subsection{Calculation of J-R Curve from Pipe Experiment 1.1.1.28}

The calculation of the J-R curve from the pipe experiment was possible using the $\eta$-factor J-estimation scheme method (Refs. 4.11 and 4.12). The $\eta$-factor analysis is a method used to estimate the J-R curve for a pipe experiment from the experimental data. It is a simple method used in lieu of threedimensional finite element analysis. The energy absorbed during the test, i.e., the area under the moment-rotation or load-displacement curve, is proportional to the fracture resistance through a geometric term, i.e., the $\eta$-factor. In this method, $J$ is separated into an elastic and plastic component.

$$
\mathrm{J}_{\text {Total }}=\mathrm{J}_{\mathrm{e}}+\mathrm{J}_{\mathrm{p}}
$$

The elastic component of J for a circumferential through-wall crack (TWC) is derived from an elastic solution in the GE/EPRI J-estimation scheme handbook (Ref. 4.1).

$$
\mathrm{J}_{\mathrm{e}}=\frac{\mathrm{R}_{\mathrm{m}}^{2} \pi \mathrm{cF} \mathrm{F}^{2}\left(\mathrm{c} / \mathrm{b}, \mathrm{R}_{\mathrm{m}} / \mathrm{t}\right) \mathrm{M}^{2}}{E I^{2}}
$$

where

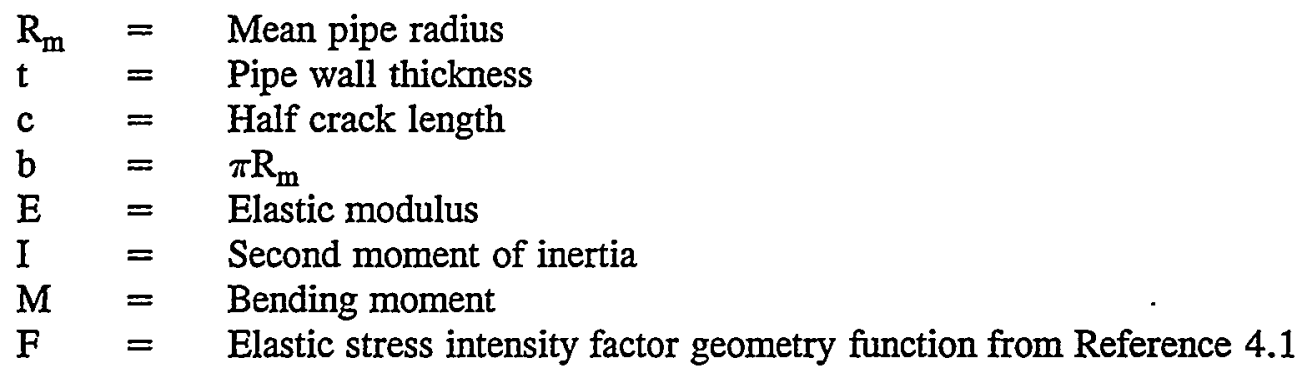

The plastic component of $\mathrm{J}$ for a circumferential TWC can be calculated from Equation 4-3.

$$
\mathrm{J}_{\mathrm{p}}=\int_{0}^{\Delta_{\mathrm{PL}}} \eta(\theta) \mathrm{Pd} \Delta_{\mathrm{PL}}+\frac{2}{\mathrm{R}_{\mathrm{m}}} \int_{c_{o}}^{c} \gamma(\theta) \mathrm{J}_{\mathrm{p}} \mathrm{dc}
$$

where

$$
\begin{array}{lll}
\Delta_{\mathrm{PL}} & = & \text { Plastic displacement } \\
\mathrm{P} & = & \text { Total applied load in a four-point bend test } \\
\mathrm{c}_{\mathrm{O}} & = & \text { Initial half crack length } \\
\theta & =\text { Half crack angle }
\end{array}
$$




$$
\begin{gathered}
\eta(\theta)=\frac{-\mathrm{h}^{\prime}(\theta)}{\mathrm{R}_{\mathrm{m}^{\mathrm{t}}} \mathrm{h}(\theta)} \\
\gamma(\theta)=\frac{\mathrm{h}^{\prime \prime}(\theta)}{\mathrm{h}^{\prime}(\theta)} \\
\mathrm{h}(\theta)=\cos \left(\frac{\theta}{2}\right)-0.5 \sin (\theta)
\end{gathered}
$$

where $h^{\prime}(\theta)$ and $h^{\prime \prime}(\theta)$ are the first and second derivatives of $h(\theta)$ with respect to $\theta$, respectively.

The plastic component of the displacement, $\Delta_{\mathrm{PL}}$, can be obtained by subtracting the elastic component of the uncracked-pipe displacement $\left(\Delta_{\mathrm{EL}}^{\mathrm{NC}}\right)$, the elastic component of displacement due to the crack $\left(\Delta_{\mathrm{ED}}^{\mathrm{C}}\right)$, and the elastic component of the displacement due to the machine compliance $\left(\Delta_{\mathrm{EL}}^{\mathrm{M}}\right)$, from the measured load-line displacements $(\Delta)$.

$$
\Delta_{\mathrm{PL}}=\Delta-\Delta_{\mathrm{EL}}^{\mathrm{NC}}-\Delta_{\mathrm{EL}}^{\mathrm{C}}-\Delta_{\mathrm{EL}}^{\mathrm{M}}
$$

where

$$
\begin{gathered}
\Delta_{\mathrm{EL}}^{\mathrm{NC}}=\frac{(z-\mathrm{L})^{2}(\mathrm{z}+2 \mathrm{~L}) \mathrm{P}}{48 \mathrm{EI}} \\
\Delta_{\mathrm{EL}}^{\mathrm{C}}=\frac{4 \mathrm{R}_{\mathrm{m}} c V_{2}\left(\mathrm{c} / \mathrm{b}, \mathrm{R}_{\mathrm{m}} / \mathrm{t}\right) \mathrm{M}}{\mathrm{EI}} \\
\Delta_{\mathrm{EL}}^{\mathrm{M}}=\mathrm{C}_{\mathrm{M}} \mathrm{P}
\end{gathered}
$$

where

$$
\begin{array}{lll}
\mathrm{z} & = & \text { Outer span in a four-point bend test } \\
\mathrm{L} & =\text { Inner span in a four-point bend test } \\
\mathrm{V}_{2}= & \text { Compliance function from Reference } 4.1 \\
\mathrm{C}_{\mathrm{M}}= & \text { Test machine compliance }
\end{array}
$$


The second term on the right side of Equation 4-3 represents a contribution to J due to crack growth, which is equal to zero until crack initiation. The plastic component of $\mathrm{J}, \mathrm{J}_{\mathrm{p}}$, after crack initiation can be derived on the basis of Equation 4-3 by repeating the calculations until $\mathrm{J}_{\mathrm{p}}$ converges.

The results of these $\eta$-factor calculations are shown in Table 4.6 and Figure 4.13. Table 4.6 shows a comparison of the calculated $J_{i}$ value from Experiment 1.1.1.28 with the $J_{i}$ values obtained from $C(T)$ specimens for the different materials (i.e., carbon steel pipe, stainless steel safe end, and bimetallic weld fusion line) which make up this weldment. Figure 4.13 shows the full J-R curve from the pipe experiment along with the J-R curve from $2 \mathrm{~T} \mathrm{C}(\mathrm{T})$, sharp-machine-notch, fusion-line specimens. The $\mathrm{J}-\mathrm{R}$ curves for the fusion-line $\mathrm{C}(\mathrm{T})$ specimens include both the actual data as well as extrapolated J-R curves using the power-law extrapolation method discussed earlier, see Table 4.2.

Figure 4.13 shows that the value of $\mathrm{J}$ at crack initiation $\left(\mathrm{J}_{\mathrm{i}}\right)$, and subsequent $\mathrm{J}-\mathrm{R}$ curve, for the pipe experiment with a crack at the interface of the A516 Grade 70 carbon steel pipe and Inconel 182 buttering passes were significantly higher than the $\mathrm{J}_{\mathrm{i}}$ value and $\mathrm{J}-\mathrm{R}$ curve for the crack in a similar location in a $C(T)$ specimen. A similar trend where the pipe $J_{i}$ value is higher than the $C(T)$ specimen $\mathrm{J}_{\mathrm{i}}$ value has been reported previously for Subtask 1.2 of the IPIRG-1 program (Ref. 4.13). The fact that the J-R curve for the pipe experiment begins to diverge from that of the fusion line $C(T)$ specimens is understandable since the crack in the pipe experiment did not continue to grow along the fusion line. Almost immediately after crack initiation, the crack turned slightly and grew in the carbon steel pipe material [as it did in the $\mathrm{C}(\mathrm{T})$ specimens] and then eventually returned back to the fusion line after $180 \mathrm{~mm}$ (7 inches) of crack growth.

Table 4.6 Comparison of $J$ at crack initiation $\left(J_{i}\right)$ values from $\eta$-factor analysis for Pipe Experiment 1.1.1.28 with $\mathrm{J}_{\mathrm{i}}$ values from the $C(T)$ specimens machined from the different materials that make up the bimetallic weldment

\begin{tabular}{cccc}
\hline \multicolumn{4}{c}{$\mathrm{J}$ at Crack Initiation, $\mathrm{kJ} / \mathrm{m}^{2}$} \\
\hline & \multicolumn{3}{c}{$\mathrm{C}(\mathrm{T})$ Specimen Values } \\
\cline { 2 - 4 } $\begin{array}{c}\text { Pipe } \\
\text { Experiment }\end{array}$ & $\begin{array}{c}\text { Carbon } \\
\text { Steel }\end{array}$ & $\begin{array}{c}\text { Stainless } \\
\text { Steel }\end{array}$ & $\begin{array}{c}\text { Bimetallic } \\
\text { Fusion } \\
\text { Line }\end{array}$ \\
\hline $2,083^{(\mathrm{a})}$ & Pipe & Safe End & $347^{(\mathrm{b})}$ \\
& $185^{(\mathrm{b})}$ & $2,233^{(\mathrm{b})}$ & \\
\hline
\end{tabular}

(a) Notch acquity = sharp machine notch.

(b) Notch acquity $=$ fatigue crack. 


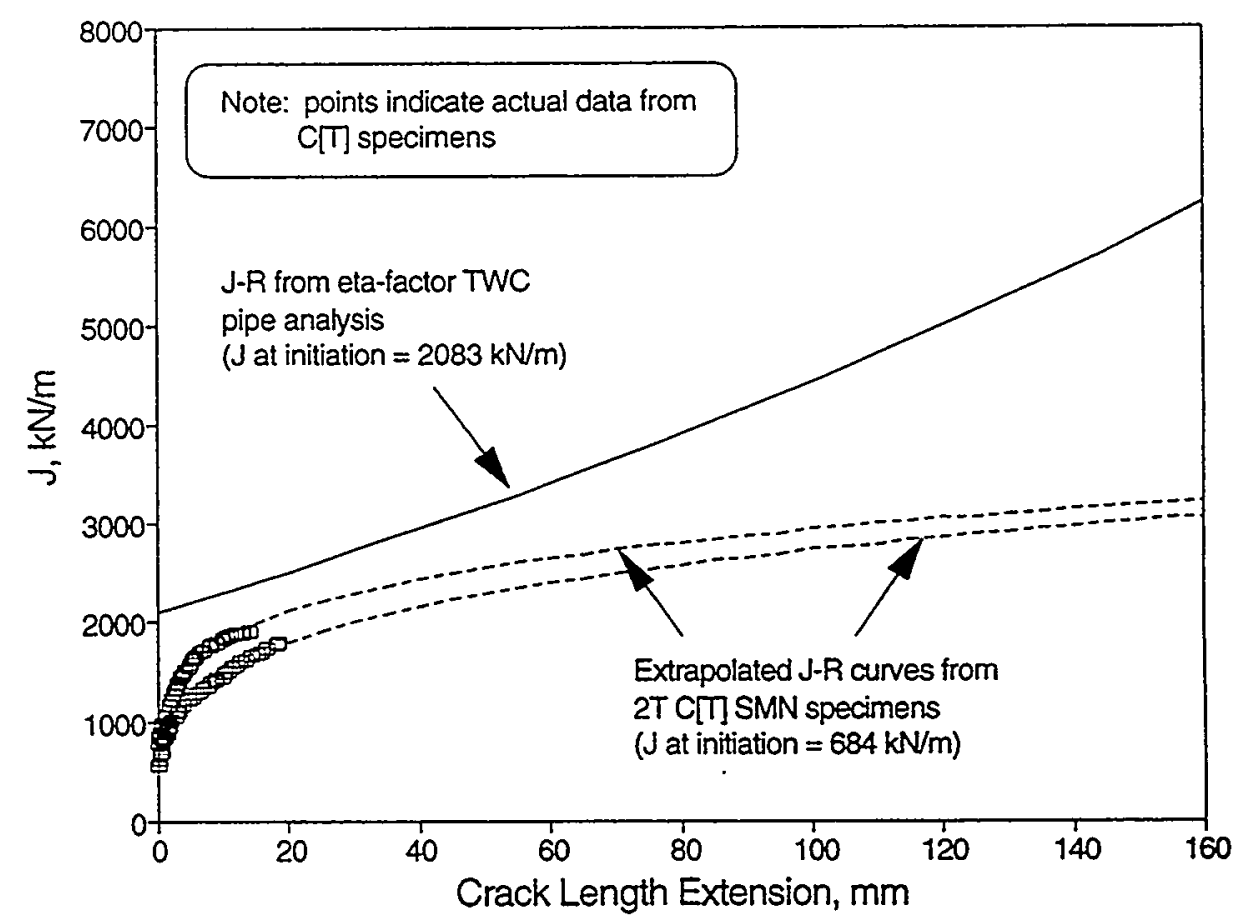

Figure 4.13 Comparison of J-resistance curve for Experiment 1.1.1.28 calculated using the $\eta$-factor method with the extrapolated $J_{D}-R$ curves from $2 T C(T)$, sharp-machine-notch, fusion-line specimens 


\subsection{References}

4.1 Kumar, V. and German, M., "Elastic-Plastic Fracture Analysis of Through-Wall and Surface Flaws in Cylinders", EPRI Report NP-5596, January 1988.

4.2 Brust, F. W., "Approximate Methods for Fracture Analyses of Through-Wall-Cracked Pipes", Battelle Report to the U.S. NRC, NUREG/CR-4853, February 1987.

4.3 Klecker, R., Brust, F. W., and Wilkowski, G., "NRC Leak-Before-Break (LBB.NRC) Analysis Method for Circumferentially Through-Wall Cracked Pipes Under Axial Plus Bending Loads", NUREG/CR-4572, May 1986.

4.4 Paris, P.C. and Tada, H., "The Application of Fracture Proof Design Methods Using Tearing Instability Theory to Nuclear Piping Postulating Circumferential Through-Wall Cracks", NUREG/CR-3464, September 1983.

4.5 Milne, I., Ainsworth, R. A., Dowling, A. R., and Stewart, A. T., "Assessment of the Integrity of Structures Containing Defects", R/H/R6-Rev. 3, Published by Central Electric Generating Board, England, May 1986.

4.6 Kanninen, M. F. and others, "Mechanical Fracture Predictions for Sensitized Stainless Steel Piping with Circumferential Cracks", Final Report, EPRI NP-192, September 1976.

4.7 Kanninen, M. F. and others, "Instability Predictions for Circumferentially Cracked Type 304 Stainless Steel Pipes Under Dynamic Loadings", Final Report on EPRI Project T118-2, by Battelle Columbus Laboratories, EPRI Report No. NP-2347, April 1982.

4.8 Wilkowski, G. M. and Scott, P. M., "A Statistical Based Circumferentially Cracked Pipe Fracture Mechanics Analysis for Design or Code Implementation", Nuclear Engineering and Design, Vol. 111, 1989, pp 173-187.

4.9 ASME Boiler and Pressure Vessel Code, Section XI, Appendix C, 1992 Edition, July 1992.

4.10 ASME Boiler and Pressure Vessel Code, Section XI, Appendix H, 1992 Edition, July 1992.

4.11 Zahoor, A. and Kanninen, M. F., "A Plastic Fracture Mechanics Prediction for Fracture Instability in a Circumferentially Cracked Pipe in Bending - Part I. J-Integral Analysis", Journal of Pressure Vessel Technology, Vol. 103, 1981, pp 352-358.

4.12 Pan, J., Ahmad, J. A., Kanninen, M. F., and Popelar, C. H., "Application of a Tearing Instability Analysis for Strain Hardening Materials to a Circumferentially Cracked Pipe in Bending", in ASTM STP 833, 1984, pp 721-748. 
4.13 Wilkowski, G., Kramer, G., Vieth, P., Francini, R., and Scott, P., "The Effect of Dynamic and Cyclic Loading During Ductile Tearing on Circumferentially Cracked Pipe-Analytical Results", Proceedings from ASME PVP Conference, Vol. 280, pp 221-240, June 1994. 


\section{DISCUSSION AND SIGNIFICANCE OF RESULTS}

As alluded to earlier, the results from the efforts described in Sections 2, 3, and 4 of this report are applicable only to the one class of bimetallic welds evaluated as part of this effort, i.e., a lower strength carbon steel pipe material, buttered with an Inconel 182 weld rod, welded to a stainless steel safe end with an Inconel weld procedure. If the specific plant application involves another class of bimetallic welds, e.g., a higher strength reactor pressure vessel nozzle welded to a stainless steel piping system using a stainless steel weld procedure, then the results and conclusions drawn from these efforts may not be applicable. In this section of the report, the specific results from the material characterization efforts, the pipe experiments, and the analyses of Experiment 1.1.1.28 are first discussed. After discussing the results from these efforts, the potential fracture behavior of different classes of bimetallic welds, involving different material combinations, are discussed.

\subsection{Discussion of Results from Material Characterization, Pipe Experiments, and Analyses Efforts}

In this section of the report, the key results from the material characterization efforts, the pipe experiments, and the analyses of Experiment 1.1.1.28 are discussed.

In Section 2 of this report, the results of the material characterization efforts for the materials associated with this bimetallic weld were presented. Table 5.1 shows a summary table of the tensile properties of the three predominant materials that make up this weldment, i.e., the carbon steel pipe, the stainless steel safe end, and the Inconel shielded-metal-arc weld (SMAW). Also included in Table 5.1 are the tensile properties for a stainless steel weld, i.e., the stainless steel submerged-arc weld (SAW) evaluated in the IPIRG-1 program (DP2-A8W) (Ref. 5.1). As can be seen in Table 5.1 the Inconel 182 SMAW is considerably stronger than either the F316 stainless steel safe end or the A516 Grade 70 carbon steel pipe materials. This weld metal is also considerably stronger than the stainless steel submerged-arc weld evaluated in IPIRG-1.

Table 5.1 Comparison of quasi-static tensile yield and ultimate tensile strengths at $288 \mathrm{C}(550 \mathrm{~F})$ of the three materials that make up the bimetallic weld evaluated in this program

\begin{tabular}{lcc}
\hline \multicolumn{1}{c}{ Material } & $\begin{array}{c}\text { Yield Strength, } \\
\text { MPa (ksi) }\end{array}$ & $\begin{array}{c}\text { Ultimate Tensile Strength, } \\
\text { MPa (ksi) }\end{array}$ \\
\hline Carbon steel pipe $^{(a)}$ & $210(30.5)$ & $510(73.9)$ \\
Stainless steel safe end & $157(22.8)$ & $415(60.2)$ \\
Inconel SMAW & $372(54.0)$ & $599(86.9)$ \\
Stainless steel SAW & $258(37.4)$ & $459(66.5)$ \\
from IPIRG-1 (DP2-A8W) & & \\
\hline
\end{tabular}

(a) For specimen machined near the midwall of the pipe. 
Table 5.2 shows a summary of the $J$ values at crack initiation $\left(J_{i}\right)$ for three of the materials that make up this bimetallic weld, i.e., the carbon steel pipe, the stainless steel safe end, and the fusion line of the carbon steel pipe and the Inconel 182 buttering passes. Also included in Table 5.2 is the quasistatic $\mathrm{J}_{\mathrm{i}}$ value for the stainless steel SAW evaluated in IPIRG-1. Figure 5.1 shows the full J-R curves for the four materials. As can be seen in Table 5.2 and Figure 5.1, the toughness of the carbon steel pipe is less than that for the fusion-line region. This, along with the fact that the strength of the carbon steel pipe is significantly less than that of the Inconel weld, explains why the cracks in both the $C(T)$ specimens and the pipe fracture tests tended to grow in the carbon steel pipe material.

Table 5.2 Comparison of J-values at crack initiation $\left(J_{\mathbf{i}}\right)$ at $288 \mathrm{C}(550 \mathrm{~F})$ for three of the materials that make up the bimetallic weld evaluated in this program

\begin{tabular}{|c|c|c|c|c|}
\hline Material & $\begin{array}{l}\text { Planform } \\
\text { Size }\end{array}$ & $\begin{array}{c}\text { Notch } \\
\text { Geometry }^{(a)}\end{array}$ & $\begin{array}{c}\text { Percent } \\
\text { Side-Grooved }\end{array}$ & $\begin{array}{c}\mathbf{J}_{\mathrm{i}}, \\
\mathrm{kJ} / \mathrm{m}^{2}\left(\mathrm{in}-\mathrm{lb} / \mathrm{in}^{2}\right)\end{array}$ \\
\hline Carbon steel pipe & $1 \mathrm{~T}$ & FC & 20 & $185(1,055)$ \\
\hline $\begin{array}{l}\text { Stainless steel } \\
\text { safe end }\end{array}$ & $1 \mathrm{~T}$ & $\mathrm{FC}$ & 0 & $2,233(12,750)$ \\
\hline $\begin{array}{l}\text { Carbon steel/ } \\
\text { Inconel } 182 \\
\text { fusion line }\end{array}$ & $2 \mathrm{~T}$ & $\mathrm{FC}$ & 0 & $347(1,983)$ \\
\hline Stainless steel $S A W^{(b)}$ & $1 \mathrm{~T}$ & $\mathrm{FC}$ & 20 & $55(315)$ \\
\hline
\end{tabular}

(a) $\mathrm{FC}=$ fatigue precrack.

(b) Toughness properties for a stainless steel SAW tested as part of the IPIRG-1 program (Ref. 5.1). No fracture toughness properties were evaluated for the Inconel weld region of this bimetallic weld.

In Section 3 of this report, the results from the two bimetallic weld pipe fracture experiments were presented. For Experiment 1.1.1.27 no applied load data were collected, but the rest of the data were useful. Of particular interest were the crack-mouth-opening-displacement (CMOD) and crack-growth data. Plotting the CMOD data as a function of the crack-growth data provides an indication of the crack-tip-opening angle (CTOA), an indication of the fracture toughness, for the pipe experiment. Figure 3.13 is a plot of this relationship for Experiments 1.1.1.27 and 1.1.1.28. In examining Figure 3.13 , it can be seen that the crack-tip-opening angle (CTOA) in the region of about $50 \mathrm{~mm}$ ( 2 inches) to $150 \mathrm{~mm}$ (6 inches) of crack growth for Experiment 1.1.1.27 is approximately 50-percent higher than the CTOA in this same crack growth region for Experiment 1.1.1.28. Note also that the fracture surface for Experiment 1.1.1.28 exhibits regions in which the crack turned out of the carbon steel pipe material and grew back into the weld for a short distance. When it did so, the contour of the fracture became extremely flat, typically indicating a low toughness region. 


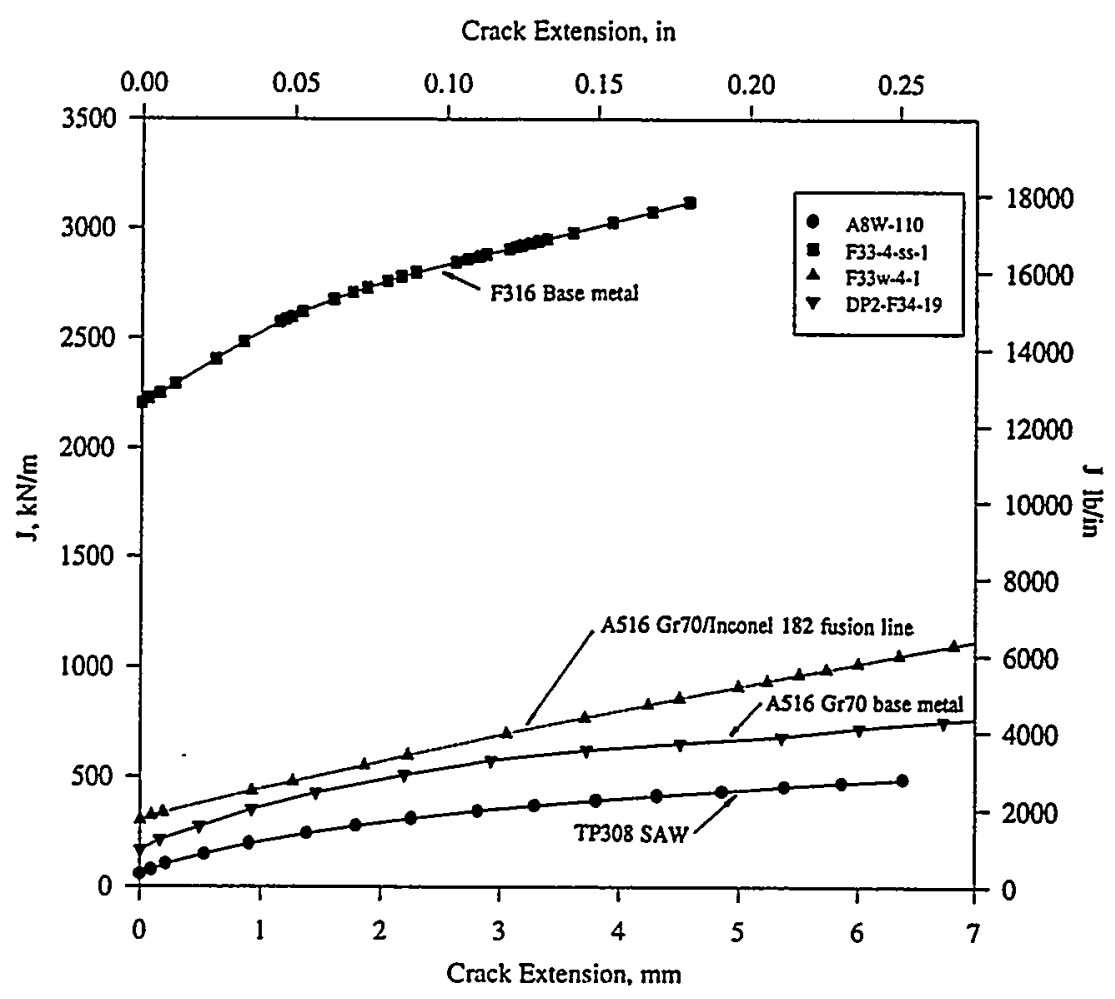

Figure 5.1 J-R curves for F316 stainless steel safe end, A516 Grade 70 carbon steel pipe, and fusionline of the carbon steel and Inconel 182 buttering passes. Also shown on this figure is the J-R curve for a stainless steel submerged-arc weld evaluated in IPIRG-1 (Ref. 5.1).

For Experiment 1.1.1.28 applied load data were obtained. As such, it was possible to compare the crack-initiation moments and the maximum moments from this experiment with results from various fracture prediction analyses. Such comparisons are made in Section 4 of this report, see Tables 4.4 and 4.5. Comparisons were made using a number of fracture prediction methods using the tensile properties of the carbon steel pipe, stainless steel safe end, and Inconel weld materials. In examining Tables 4.4 and 4.5 , it can be seen that the use of the carbon steel pipe tensile properties in the analyses resulted in the most accurate predictions. The use of the carbon steel tensile properties typically resulted in a slight underprediction of the initiation and maximum moments. When the Inconel weld tensile data were used in the analyses, the analysis methods often overpredicted the initiation and maximum moments; and when the stainless steel safe end tensile data were used, the analysis methods tended to significantly underpredict the initiation and maximum moments. In some cases the extent of the underprediction was nearly a factor of 2 .

Figure 5.2 shows the applied bending stress, i.e., the crack section moment normalized by the section modulus of the pipe section, as a function of the crack-section rotation data for the three cold-leg pipe experiments conducted as part of the Degraded Piping (Ref. 5.2) and this program, i.e., the carbon steel base metal (4111-6), carbon steel weld (4141-7), and bimetallic weld (1.1.1.28) experiments. As can be seen there is not much difference in the moment-rotation response between the three experiments up to about 2-degrees of rotation. After that point, the moments, and thus stresses, for the bimetallic weld experiment begin to drop off whereas the moments and stresses for the other two 
experiments continue to increase or remain constant. This may be attributed to the fact that the crack in the bimetallic weld experiment mainly grew in the circumferential direction, whereas the cracks in the other two cold-leg pipe experiments turned out of the circumferential plane almost immediately after crack initiation. The crack in the cold-leg carbon steel weld experiment, i.e., Experiment 41417 , turned 45 degrees from the circumferential plane at one crack tip and turned 60 degrees from the circumferential plane at the other crack tip. The crack in the cold-leg carbon steel base metal experiment, i.e., Experiment 4111-6, turned almost 90 degrees from the circumferential crack plane at both crack tips and grew axially (without any hoop stress) for $120 \mathrm{~mm}$ (4 inches). The fact that the crack in this bimetallic weld pipe experiment grew more in the circumferential direction than did the cracks in the other two cold-leg pipe experiments implies that the applied moments due to the applied displacement-controlled loading for this bimetallic weld experiment should probably drop off faster than would the moments for the other two experiments. The reasoning behind this contention is that the remaining ligament would decrease faster in this bimetallic weld pipe experiment than in the other two cold-leg pipe experiments.

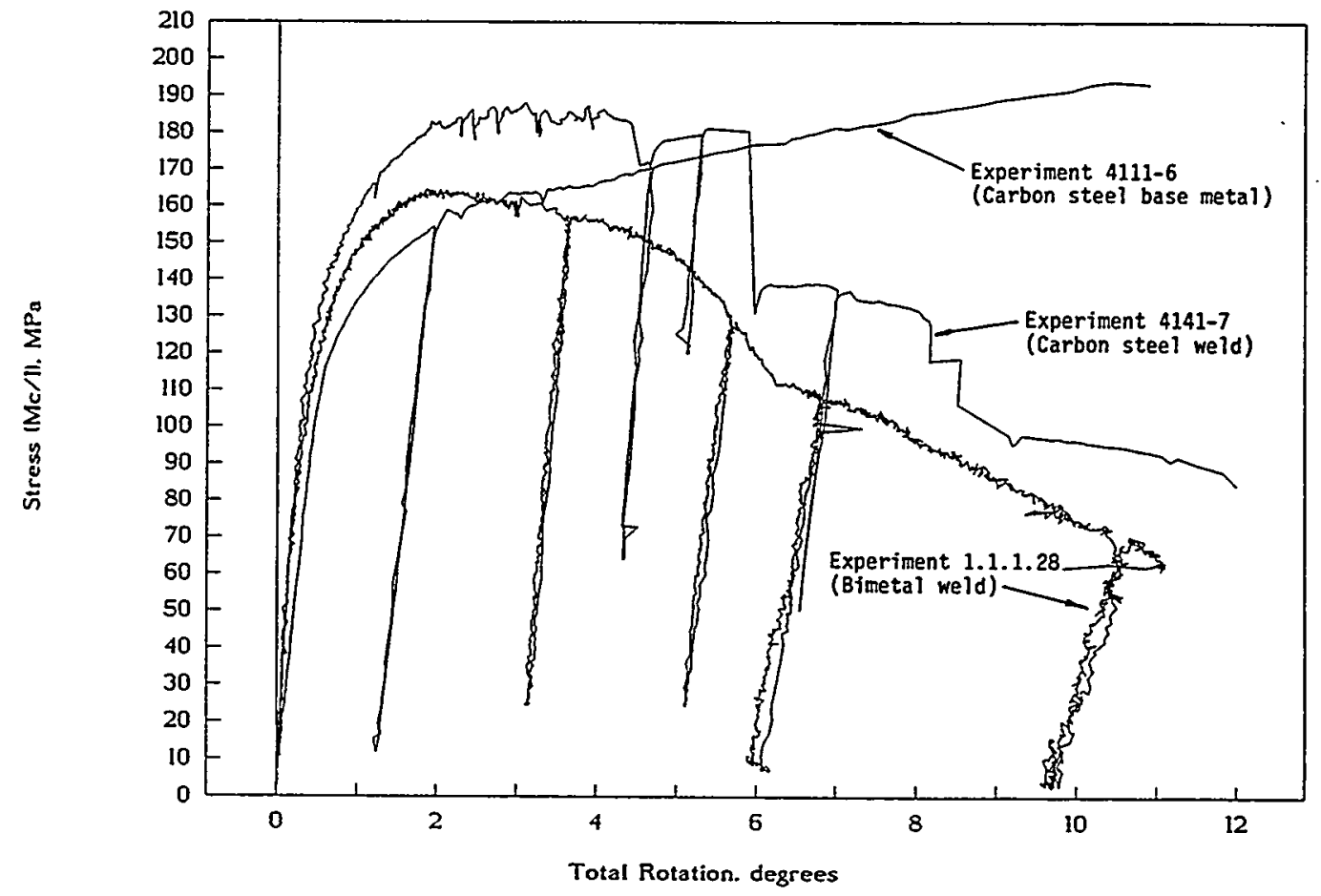

Figure 5.2 Bending stress (i.e., crack section moment normalized by uncracked pipe section modulus) for the three cold-leg pipe experiments conducted as part of the Degraded Piping Program (Ref. 5.2) and this program 
Table 5.3 shows a comparison of the ratio of the maximum experimental moment to the predicted Net-Section-Collapse [NSC] moment for the three cold-leg pipe fracture experiments. Note, in each case the flow stress used in the NSC analysis was the average of the yield and ultimate strengths of the carbon steel pipe material. As can be seen in Table 5.3, the results for the cold-leg bimetallic weld experiment (Experiment 1.1.1.28) are not drastically different from those for the cold-leg base metal experiment (4111-6) or the cold-leg carbon steel weld experiment (4141-7) from the Degraded Piping Program. The ratio of the maximum experimental moment to the NSC predicted moment for Experiment 1.1.1.28 was about only 15 to 20 percent less than ratio of the maximum experimental moment to the NSC predicted moment for the other two cold-leg pipe experiments. The fact that the ratio of the maximum experimental moment to the NSC predicted moment for this bimetallic weld cold-leg pipe experiment is less than the ratio of the experiment-to-predicted moments for the other two cold-leg pipe experiments can probably be partially explained by the fact that the crack is this bimetallic weld pipe experiment grew in the circumferential direction, whereas the cracks in the other two cold-leg pipe experiments grew helically or axially. As a result, it may be contended that if the cracks in all three experiments had grown in the initial circumferential crack plane, then the agreement between experiments may have been even better than observed. This agreement in maximum moments between experiments is of further note when one considers the fact that the amount of scatter observed in pipe fracture results between experiments of like materials is typically 5 to 10 percent. The fact that the bimetallic weld pipe experiment behaved like the other two cold-leg pipe experiments should probably not be surprising when one considers the fact that shortly after the crack initiated, the crack turned out of the fusion line and began to grow into the carbon steel pipe material parallel to the fusion line. Consequently, it appears that the fracture behavior of this class of bimetallic weld can probably be explained based on the carbon steel pipe base metal material property data. However, as will be discussed next, such may not always be the case when one considers other classes of bimetallic welds.

Table 5.3 Comparison of the maximum experimental moments divided by Net-SectionCollapse (NSC) predicted moments for the three cold-leg pipe experiments

\begin{tabular}{|c|c|c|c|c|c|}
\hline $\begin{array}{c}\text { Experiment } \\
\text { Number }\end{array}$ & Program & $\begin{array}{c}\text { Crack } \\
\text { Location }\end{array}$ & $\begin{array}{l}\text { Maximum } \\
\text { Experimental } \\
\text { Moment, } \\
\text { MN-m }\end{array}$ & $\begin{array}{c}\text { NSC } \\
\text { Predicted } \\
\text { Moment, } \\
\text { MN-m }\end{array}$ & Expt/NSC \\
\hline $4111-6$ & Degraded Piping(a) & Base Metal & 7.20 & 7.03 & 1.024 \\
\hline $4141-7$ & Degraded Piping ${ }^{(a)}$ & CS Weld ${ }^{(b)}$ & 8.40 & $8.54^{(c)}$ & 0.983 \\
\hline 1.1.1.28 & Short Cracks & Bimetallic Weld & 6.95 & $8.41^{(c)}$ & 0.827 \\
\hline
\end{tabular}

(a) Reference 5.2.

(b) $\mathrm{CS}=$ carbon steel

(c) Using carbon steel base metal actual properties with $\sigma_{\mathrm{f}}=\left(\sigma_{\mathrm{y}}+\sigma_{\mathrm{u}}\right) / 2$ 


\subsection{Potential Fracture Behavior of Different Bimetallic Weld Configurations Involving Different Material Combinations}

As noted earlier, the results and conclusions drawn as a result of the efforts described in Sections 2 , 3 , and 4 of this report are applicable only to the one class of bimetallic welds evaluated, i.e., a lower strength carbon steel pipe material, buttered with an Inconel 182 weld rod, which is welded to a stainless steel safe end using an Inconel SMAW process. This is the configuration used by CE for joining their ferritic cold-leg pipe to a stainless steel safe end that in turn is welded to a stainless steel pump housing on one of the reactor coolant pumps. It is not known if CE has always used this practice. Other possible bimetallic weld applications include cases such as the welding of stainless steel piping to carbon steel nozzles on the reactor pressure vessel or the steam generator in a Westinghouse PWR, or the joining of the higher strength ferritic safety injection nozzles on the coldleg piping system to the stainless steel safety-injection-nozzle safe ends, which in turn are welded to the stainless steel safety injection-line piping system in a CE PWR. These other types of bimetallic welds may behave much differently from the bimetallic welds evaluated as part of this effort. In this section of this report, potential differences in the fracture behavior of different classes of bimetallic welds involving different material combinations are discussed.

The welds evaluated in this effort were fabricated by first buttering the bevel on the A516 Grade 70 carbon steel pipe with an Inconel 182 weld rod, see Figure 2.1. This buttered pipe was then welded to the F316 stainless steel safe end using an Inconel shielded-metal-arc-weld (SMAW) process. Other bimetallic welds are made by buttering the ferritic material with a stainless steel weld rod, instead of the Inconel 182 weld rod. When the stainless steel material is used to butter the carbon steel material instead of using Inconel, the propensity for decarburization of the carbon steel heat-affected-zone (HAZ) is increased. The carbon in the ferritic material wants to migrate to the stainless steel weld due to the fact that the carbon is more soluble in the stainless steel than it is in the carbon steel. Lundin indicates in Reference 5.3 that decreasing the nickel content of the filler metal alters the carbon solubility, making the carbides more stable, changing the diffusivity, and in general increasing the carbon migration from the ferritic material. As a result, when stainless steel metal rod is used instead of Inconel, there is a depletion of carbon in the ferritic HAZ, which results in a softening, i.e., a loss in strength in this area.

Adjacent to this softer carbon-depleted zone in the ferritic heat-affected-zone is a carbon-enriched zone in the stainless filler metal. This carbon-enriched zone is higher in hardness, and probably in strength, that the surrounding bulk filler metal. These zones of carbon-depleted and carbon-enriched materials are immediately adjacent to one another providing for a situation in which the material properties can change significantly across a very narrow region. Lundin, in Reference 5.3, highlights extreme cases where the hardness between the carbon-depleted heat-affected-zone and the carbonenriched filler metal changes 240 diamond pyramid hardness (DPH) over a span of only $0.25 \mathrm{~mm}$ ( 0.010 inch). A change of $240 \mathrm{DPH}$ may be equivalent to approximately a $825 \mathrm{MPa}$ (120 ksi) change in ultimate strength. Consequently, the circumstances may possibly exist in which the carbondepleted soft zone is restrained by a much harder and stronger carbon-enriched zone, and it is in this narrow band that plastic strains may accumulate. 
In a program conducted at the Nuclear Research Institute (NRI) in Rez, Czech Republic ${ }^{*}$, Charpy and J-resistance curves for several such welds were determined. The data for one of those welds are summarized in Figure 5.3. For comparison purposes, the data from the bimetallic weld evaluated in this program are also included on Figure 5.3. As can be seen in Figure 5.3, the fusion-line toughness of the weld evaluated in this program was a factor of three higher than the fusion-line toughness of the weld evaluated by NRI. The hardness minimum in the decarburized zone of the carbon steel adjacent to the fusion line was also determined in the NRI program. Furthermore, some of the compact specimens NRI tested from this region (some of which were tested at room temperature) failed by cleavage of the carbon steel about $1 \mathrm{~mm}(0.04 \mathrm{inch})$ away from the fusion line, i.e., beyond the decarburized layer.

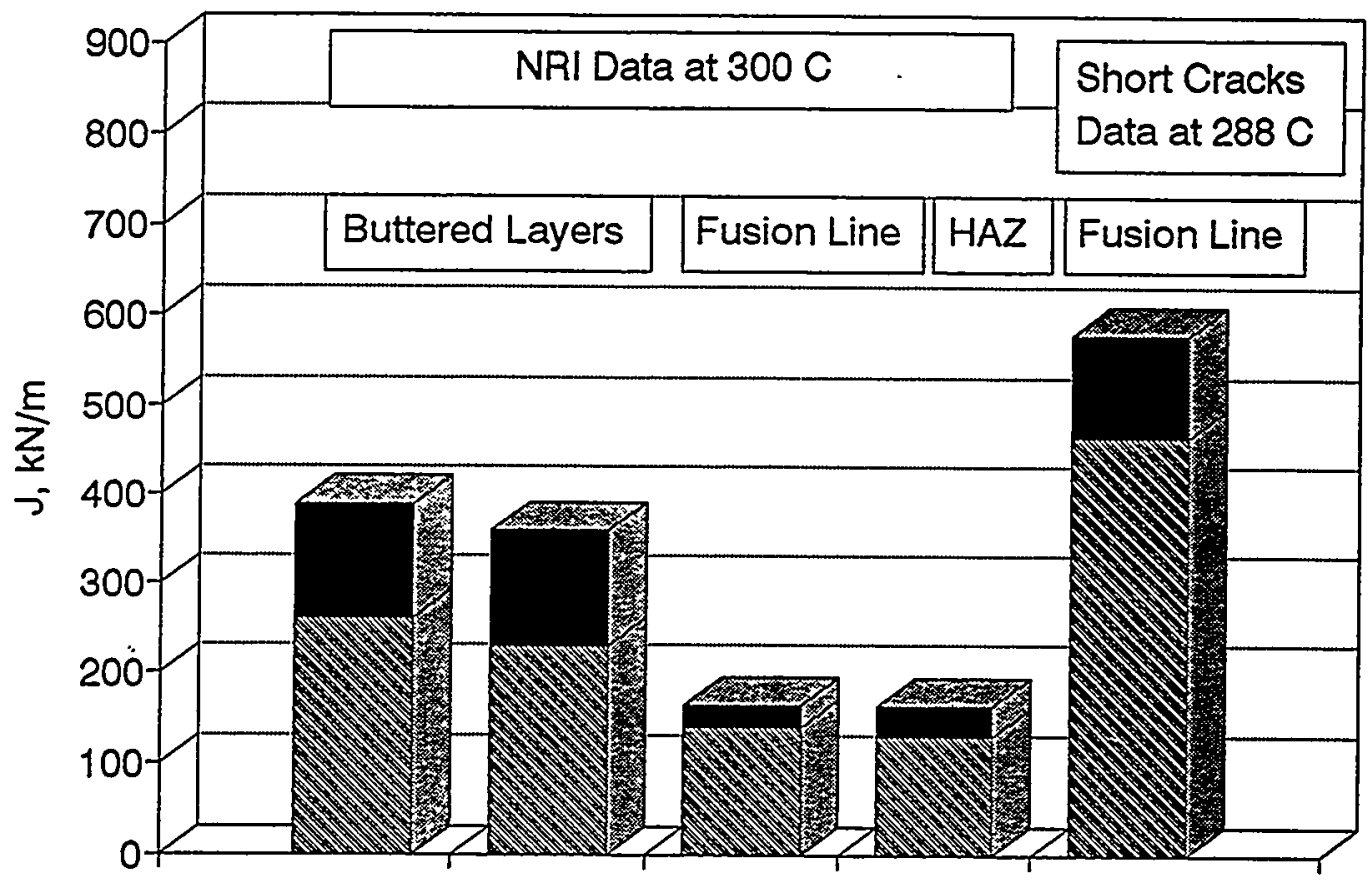

\section{$1 \mathrm{~mm}$ Crack Growth $2 \mathrm{~mm}$ Crack Growth}

Figure $5.3 \mathrm{~J}$-values at $1 \mathrm{~mm}(0.04$ inch) and $2 \mathrm{~mm}(0.08$ inch) of crack extension for bimetallic welds evaluated by NRI-Rez and from this program.

Another factor influencing the fracture behavior of bimetallic weld joints is the differences in the coefficient of thermal expansion between the dissimilar materials. The nickel-based Inconel weld metals have a coefficient of thermal expansion between those of the ferritic and austenitic base metals. The coefficient of thermal expansion of the Inconel-type materials is $15.3 \mathrm{~mm} / \mathrm{mm} / \mathrm{C}(8.5 \mathrm{in} / \mathrm{in} / \mathrm{F})$

* Private communication between Dr. Jaroslav Joch of Nuclear Research Institute in Rez, Czech Republic and Dr. Gery Wilkowski of Battelle Columbus. 
compared with $18.7 \mathrm{~mm} / \mathrm{mm} / \mathrm{C}(10.4 \mathrm{in} / \mathrm{in} / \mathrm{F})$ for stainless steel and $14.8 \mathrm{~mm} / \mathrm{mm} / \mathrm{C}(8.2 \mathrm{in} / \mathrm{in} / \mathrm{F})$ for carbon steel. As a result, at elevated temperature service, the major differential expansion stresses will be located primarily at the tougher stainless steel/weld metal interface if Inconel weld metal is used; whereas, the major differential expansion stresses will be located primarily at the less tough carbon steel/weld metal interface if stainless steel weld metal is used. Consequently, the use of the Inconel weld metal creates a situation where the higher stresses due to differential thermal expansion occur in a region that may be more tolerant of defects. (Efforts to determine stainless steel weld fusion-line toughness are described in NUREG/CR-6251, which is in press at the time this report was written.)

Another potential difference in weld configuration includes the case where the ferritic material is a higher strength reactor pressure vessel steel nozzle forging, such as A508 or the German RPV steel $23 \mathrm{NiMoCr} 36$, instead of the relatively low strength carbon steel pipe material evaluated in this program, i.e., A516 Grade 70. Such were the welds evaluated by Devaux (Ref. 5.4). Devaux studied bimetallic welds in which the stainless steel weld was softer than the carbon steel material, and found that cracks at the fusion line grew into the stainless steel weld. While the hardness distribution and preferred alloy phase for the cracking reported by Devaux were opposite to that in the pipe weld evaluated in this report, the theoretical analysis reported by Devaux is still relevant; i.e., provided failure is by ductile fracture, the crack will propagate into the softer material. Furthermore, the softer material has an apparent toughness that is less than its toughness measured using a homogeneous specimen because plastic flow in the vicinity of the bimetallic interface is constrained by the harder surrounding material. Data from the HDR program (Ref. 5.5) indicate that both the strength and toughness of the reactor pressure vessel steel 23NiMoCr 36 are significantly higher than the strength and toughness of a typical stainless steel submerge-arc weld (SAW) evaluated in the Degraded Piping and IPIRG programs or the Inconel weld evaluated in this program. As such, it would be expected that the crack in such a bimetallic weld would want to grow in the weld instead of the base metal material. It is also of note that for the instances when the cracks in the $C(T)$ specimens and pipe fracture experiments conducted as part of this effort grew in the weld, it was evident from observing the fracture surfaces that the fracture resistance was very low. In those instances there were almost no shear lips on the fracture.

Finally, when one considers the case where a higher strength reactor pressure vessel steel is buttered and welded with a stainless steel weld rod instead of an Inconel weld rod, the potential for an adverse strength and toughness condition is especially high. In those cases, not only will the crack probably want to grow into the weld metal more than in the case evaluated in this program, but also the potential for the formation of a softer decarburized zone in and around the carbon steel heat-affectedzone, with an associated lower strength and toughness, will be high. If such is the case, the conditions may exist for the creation of a situation where the crack is growing in a very narrow band of lower strength/lower toughness material where the plastic strains will accumulate. The potential would then exist for a low toughness failure. 


\subsection{References}

5.1 Marschall, C. W., Landow, M. P., and Wilkowski, G. M., "Loading Rate Effects on Strength and Fracture Toughness of Pipe Steels Used in Task 1 of the IPIRG Program", NUREG/CR6098, October 1993.

5.2 Wilkowski, G. M. and others, "Degraded Piping Program - Phase II, Summary of Technical Results and Their Significance to Leak-Before-Break and In-Service Flaw Acceptance Criteria", March 1984 - January 1989, NUREG/CR-4082, Vol. 8, March 1989.

5.3 Lundin, C. D., "Dissimilar Metal Welds--Transition Joints Literature Review", Welding Journal, Vol. 61, pp 58s-63s, 1982.

5.4 Devaux, J. C. and others, "Prediction of Overall Toughness of Bimetallic Welds through Numerical Analysis According to the Local Approach Tearing to Fracture", pp 325-335 in Numerical Methods in Fracture Mechanics, A.R. Luxmore, Ed., Pineridge Press, Swansea, U.K., 1987.

5.5 Olson, R. J. and others, "Validation of Analysis Methods for Assessing Flawed Piping Subjected to Dynamic Loading", NUREG/CR-6234, August 1994. 


\section{CONCLUSIONS}

The major conclusion drawn as a result of the efforts described in this report was that the fracture behavior of the bimetallic weld evaluated in this program can best be evaluated using the strength and toughness properties of the carbon steel pipe material in conjunction with conventional elastic-plastic or limit-load fracture mechanics analysis methods. When the fracture ratio (i.e., the ratio of the experimental maximum moment to the predicted Net-Section-Collapse moment) for this bimetallic weld, cold leg pipe experiment (1.1.1.28) was compared with the fracture ratios for the other two through-wall-cracked, cold leg pipe experiments conducted as part of the Degraded Piping Program, i.e., the carbon steel base metal (4111-6) and the carbon steel weld (4141-7) experiments, it was found that the ratios of the experimental-to-predicted loads for the three experiments were very consistent with each other. In each case the maximum experimental moment was within 18 percent of the predicted Net-Section-Collapse moment. This is not surprising because the cracks in each of these experiments tended to grow into the carbon steel pipe material. It is believed that the reason the crack in this bimetallic weld experiment grew out of the fusion line and into the carbon steel pipe base material is that the strength of this carbon steel pipe material was significantly less than the strength of the weld metal.

It should be emphasized that for other classes of bimetallic welds, involving different material combinations, that the above conclusions may not hold true. The strength and toughness properties of other classes of bimetallic welds may be such that the crack may grow into the weldment, which may be potentially lower in strength and lower in toughness than either of the base plate materials. If such is the case, then the plasticity may be constrained to the point that the plastic strains accumulate in the weld region. The failure moments may then be significantly less than what one would predict using the carbon steel base metal material properties in conjunction with conventional elastic-plastic fracture mechanics analysis methods. Such classes of welds include: (1) those welds for which the carbon steel material is a higher strength nozzle material, i.e, higher strength than the carbon steel pipe material evaluated in this program, and (2) those welds for which the carbon steel bevel is buttered using a stainless steel weld rod instead of the Inconel weld rod used in the weldments evaluated in this program. If a higher strength nozzle material is involved, then the cracks may want to grow in the potentially lower strength, lower toughness weld metal. If a stainless steel weld rod is used to butter the ferritic material, then conditions may exist for the formation of a softer, weaker, fusion-line region due to the depletion of the carbon in the ferritic heat-affected zone. Joch measured the toughness of such a weld and found that the fusion-line toughness was a factor of three less than the fusion-line toughness measured for the bimetallic weld evaluated in this program. If a stainless steel weld rod is used to butter a higher strength nozzle material, then the potential problems with the weldment may be compounded. 
